\title{
PROTEOLYTIC MECHANISMS INVOLVED IN THE METASTASIS OF HUMAN MELANOMA CELLS
}

\author{
Jean M. Fletcher
}

Thesis submitted for the degree of Master of Science

University of Cape Town

June 1994 
The copyright of this thesis vests in the author. No quotation from it or information derived from it is to be published without full acknowledgement of the source. The thesis is to be used for private study or noncommercial research purposes only.

Published by the University of Cape Town (UCT) in terms of the non-exclusive license granted to UCT by the author. 


\section{DECLARATION}

I, Jean M. Fletcher, hereby declare that the work on which this thesis is based is my original work (except where acknowledgements indicate otherwise) and that neither the whole work or any part of it has been, is being, or is to be submitted for another degree in this or any other University.

I empower the University to reproduce for the purpose of research either the whole or any portion of the contents in any manner whatsoever.

14 July 1994 


\section{ACKNOWLEDGEMENTS}

I would like to express my gratitude to my supervisor, Professor E.B. Dowdle, for his inspiration and help in writing this thesis, particularly during the period after his retirement from the department.

I am indebted to Professor Paul Potter for his generosity in allowing me time to complete this work.

I would like to extend my thanks to the following people:

- Dr Jill Finlayson who initiated the project and made a valuable contribution to the antisense work.

- Lizette Fick for her excellent assistance with the tissue culture of the clones

- Janet Hallet (Department of Hematology) for examining and photographing the chromosome spreads

- Gideon Hanekom who contributed to many useful discussions

- Hanne Veenstra who had the arduous task of proofreading this thesis

- The washroom staff for their friendly and efficient help

- My colleagues in the Department of Clinical Science for their advice and support

The funds for this research were provided by the South African Medical Research Council and the Staff Research Fund of the University of Cape Town. This work was performed whilst on a tenure of a post on the staff of the Hospital Department of the Cape Provincial Administration. 


\begin{abstract}
The metastatic process requires that tumour cells are capable of traversing various micro-environmental barriers, such as the basement membrane. There are various proteolytic mechanisms which could contribute to the process, plasminogen activation by tissue plasminogen activator (TPA) and urokinase plasminogen activator (UPA) is one such mechanism. Extensive reports in the literature (reviewed in the introduction) indicate that most tumour cells synthesize UPA and that it is this enzyme, particularly when receptor-bound, which plays a role in invasion.
\end{abstract}

UCT-Mel 3 is a human malignant melanoma cell line which was established in our laboratory, and has been shown to be highly metastatic in the nude mouse. This cell line is typical of many melanomas in that it synthesizes only tPA and not UPA. In part 1 of this thesis I further investigated the plasminogen activator production by these cells (at the level of MRNA as well as activity) as well as expression of plasminogen activator inhibitor PAI-1 and receptors for TPA and UPA (UPAR). UCT-Mel 3 cells expressed UPAR although uPA was not detected. I also examined cells cultured from two metastatic deposits. Interestingly, the metastatic cells produced PAI-1 which was undetected in the parent cells.

After confirming that UCT-Mel 3 do not express detectable levels of UPA, I attempted (in part 2) to determine whether IPA could play a comparable role to that of UPA in the invasive process. My strategy was to inhibit the expression of tPA via two different methods, namely the use of antisense RNA and ribozyme. I then hoped to isolate clones producing no tPA, which would have been injected into nude mice in order to assay for metastasis. Unfortunately neither of these 
methods proved to be successful in abrogating tPA expression. I was thus unable to achieve the ultimate aim of the project. However, during the course of the study a number of unforeseen problems arose. Firstly, the clonal variation within the cell population, and secondly, my inability to obtain antisense transfectants. I have speculated that a possible reason for the latter may be that the cells are in fact unable to grow in the absence of tPA. 


\section{CONTENTS}

ABBREVIATIONS

LIST OF FIGURES (iv)

LIST OF TABLES (vi)

\section{LITERATURE REVIEW:}

The role of proteases in invasion and metastasis

METASTASIS

- site-specific metastasis 2

- invasion 2

- adhesion 3

PROTEASES 4

- TPA

- UPA $\quad 8$

- regulation of PA activity 11

INVOLVEMENT OF PROTEASES IN METASTASIS

- Experimental models 14

- In vitro studies $\quad 15$

- In vivo studies 19

\section{PART 1}

Expression of plasminogen activators, UPA receptor and PAI- 1 in UCT-Mel 3 cells 


\section{Methods}

Antibody purification $\quad 26$

Fibrin plate assay for PA activity 26

Zymography 26

RNA extraction and northern blot analysis 26

Culture of metastatic deposits 28

Measurement of PA in cultured metastases 28

Southern blot analysis $\quad 28$

Measurement of PAl-1 28

Demonstration of UPAR 29

Results

PA synthesis by UCT-Mel 3 cells 32

PAI-1 synthesis by UCT-Mel 3 cells 36

Synthesis of UPAR by UCT-Mel 3 cells 38

Southern blot analysis 46

Discussion 48

\section{PART 2:}

Inhibition of tPA synthesis, clonal variation and tPA receptors in UCT-Mel 3 cells

Introduction

Methods

Construction of sense/antisense plasmids $\quad 55$

Transfection and selection with Hygromycin 56 
Chloroamphenicol acetyl transferase assay

PA release by transfected cells $\quad 59$

Polymerase chain reaction (PCR) amplification $\quad 59$

$\begin{array}{ll}\text { Ribozyme preparation } & 61\end{array}$

Clonal analysis 63

Measurement of PAl-1 64

Binding of tPA to cell surface $\quad 64$

$\begin{array}{ll}\text { Results } & 64\end{array}$

Sense and antisense plasmids $\quad 64$

Transfection by electroporation 65

Cloning of transfectants 66

$\begin{array}{ll}\text { tPA release by transfected clones } & 67\end{array}$

PCR analysis of transfected clones 68

$\begin{array}{ll}\text { Ribozyme preparation } & 70\end{array}$

$\begin{array}{ll}\text { tPA template preparation } & 71\end{array}$

$\begin{array}{ll}\text { Ribozyme catalysis } & 72\end{array}$

$\begin{array}{ll}\text { Clonal analysis } & 74\end{array}$

PAl-1 measurement of UCT-Mel 3 clones $\quad 79$

$\begin{array}{ll}\text { Cell surface-bound tPA } & 79\end{array}$

$\begin{array}{ll}\text { Discussion } & 81\end{array}$

$\begin{array}{ll}\text { APPENDIX } & 85\end{array}$

$\begin{array}{ll}\text { BIBLIOGRAPHY } & 107\end{array}$ 


\section{LIST OF ABBREVIATIONS}

\begin{tabular}{|c|c|}
\hline AM & adrenal metastasis \\
\hline ATF & amino terminal fragment \\
\hline $\mathrm{BCA}$ & bichinoninic acid \\
\hline bp & base pairs \\
\hline BSA & bovine serum albumin \\
\hline CAM & chorioallantoic membrane \\
\hline CAT & chloramphenicol acetyl transferase \\
\hline CIP & calf intestinal phosphatase \\
\hline CMV & cytomegalovirus \\
\hline $\mathrm{cpm}$ & counts per minute \\
\hline DEPC & diethyl pyrocarbonate \\
\hline DFP & diisopropylfluorophosphate \\
\hline DMSO & dimethyl sulfoxide \\
\hline DTT & dithiothreitol \\
\hline $\mathrm{ECM}$ & extracellular matrix \\
\hline EDTA & Ethylene-diamine-tetra acetate \\
\hline ELISA & enzyme-linked immunosorbent assay \\
\hline FCS & fetal calf serum \\
\hline fig. & figure \\
\hline GCG & Genetics Computer Group \\
\hline HAEC & human aortic endothelial cells \\
\hline HEPES & $\mathrm{N}-2-$ Hydroxyethylpiperazine-N'-2-ethanesulfonic acid \\
\hline HMW & high molecular weight \\
\hline $\mathrm{hr}$ & hours \\
\hline IUVEC & human umbilical vein endothelial cells \\
\hline
\end{tabular}




$\begin{array}{ll}\text { kb } & \text { kilobases } \\ \text { kD } & \text { kilodaltons } \\ \text { LM } & \text { lung metastasis } \\ \text { LMW } & \text { low molecular weight } \\ \text { LB } & \text { Luria broth } \\ \text { MOPS } & \text { 3-(N-Morpholino)propanesulfonic acid } \\ \text { mm } & \text { millimeters } \\ \text { mM } & \text { millimolar } \\ \text { Mr } & \text { molecular weight } \\ \text { nM } & \text { nanomolar } \\ \text { PA } & \text { plasminogen activator } \\ \text { PAGE } & \text { polyacrylamide gel electrophoresis } \\ \text { PAI-1 } & \text { plasminogen activator inhibitor 1 } \\ \text { PAI-2 } & \text { plasminogen activator inhibitor 2 } \\ \text { PCR } & \text { polymerase chain reaction } \\ \text { PIF } & \text { protease and inhibitor free } \\ \text { PMA } & \text { phorbol 12-myristate 13-acetate } \\ \text { RPMI1640 } & \text { Roswell Park Memorial Institute 1640 medium } \\ \text { SC-tPA } & \text { single chain tPA } \\ \text { SC-UPA } & \text { single chain uPA } \\ \text { SDS } & \text { sodium dodecyl sulfate } \\ \text { TCA } & \text { two chain tPA } \\ \text { TC-tetramethylene diamine }\end{array}$


tPA tissue plasminogen activator

TST Tris-saline-tween

UPA urokinase plasminogen activator

UPAR urokinase plasminogen activator receptor 


\section{LIST OF FIGURES}

1.1 SDS PAGE and autoradiography of 125/-labelled ATF

1.2 Double reciprocal plot of 125 -labelled ATF binding to U937 cells

1.3 Antibody titration of UCT-Mel 3 harvest fluid

1.4 SDS PAGE and zymography of UCT-Mel 3 harvest fluid and cell lysate

1.5 Northern blot analysis of tPA, UPA and PAl-1 gene expression in UCT-Mel 3 cells

$1.6 \quad$ Northern blot analysis of TPA and uPA gene expression in UCT-Mel 3 metastases

1.7 Northern blot analysis of PAl-1 gene expression in UCT-Mel 3 metastases

1.8 Northern blot analysis of UPAR gene expression in UCT-Mel 3 cells

1.9 Northern blot analysis of UPAR gene expression in UCT-Mel 3 metastases

1.10 Binding of labelled ATF to UCT-Mel 3 and U937 cells in the presence of increasing concentrations of unlabelled ATF

1.11 Binding of increasing concentrations of labelled ATF to UCT-Mel 3 and $U 937$ cells

1.12 Scatchard analysis of ATF binding to U937 and UCT-Mel 3 cells

1.13 Southern blot analysis of tPA, UPA and PAI-1 genes in UCT-Mel 3 cells

1.14 Southern blot analysis of the uPAR gene in UCT-Mel 3 cells

2.1 Diagrammatic representation of p17-CAT

$2.2 \quad$ Construction of $\mathrm{p}$ 17-tPA $\mathrm{as} / \mathrm{s}$ plasmids

$2.3 \quad$ Hygromycin titration 
2.4 Sequence and secondary structure of anti-tPA ribozyme

$2.5 \quad$ Orientation of the p17-tPA insert

2.6 CAT assay standard curve

2.7 PCR detection of $\mathrm{p} 17-\mathrm{tPA} \mathrm{A}_{\mathrm{as}}$ in transfected UCT-Mel 3 cells

2.8 PCR detection of $\mathrm{p}$ 17-tPA $A_{6}$ and p17-CAT in transfected UCT-Mel 3 cells

2.9 Cloning of the ribozyme sequence into pSp64

2.10 Orientation of PGEM1-tPA insert

2.11 Transcription of ribozyme and tPA sequences

2.12 Plasminogen activator release by UCT-Mel 3 clones

2.14 Binding of tPA to the surface of UCT-Mel 3 cells 


\section{LIST OF TABLES}

$1.1 \quad$ Details of cDNA probes

1.2 Levels of PA release by UCT-Mel 3 parent and metastatic cells

1.3 Levels of PAI-1 release by UCT-Mel 3 parent and metastatic cells

$1.4 \quad$ Scatchard analysis (U937 cells)

1.5 Scatchard analysis (UCT-Mel 3 cells)

2.1 PCR primers

2.2 Plasminogen activator release by UCT-Mel 3 cells transfected with p17-tPAas

2.3 Plasminogen activator release by UCT-Mel 3 clones 


\section{LITERATURE REVIEW}

The Role of Plasminogen Activators in Invasion and Metastasis

\section{METASTASIS/INVASION}

Perhaps the most important difference between a benign and malignant tumour resides in the ability of the latter to invade normal tissues and to metastasize to distant sites throughout the body. It is this metastatic capability which makes cancer such a difficult disease to treat.

The vascular metastatic process is thought to involve a number of steps $(1,2)$ :

1. Invasion of surrounding tissues by primary tumour cells.

2. Angiogenesis: tumours induce their own supply of blood vessels to nourish the rapidly expanding mass.

3. Intravasation: tumour cells infiltrate capillaries and enter the circulation.

4. Embolus formation: interaction of tumour cells in the bloodstream with fibrin and platelets.

4. Arrest: some of these malignant cells arrest in capillary beds at sites distant from the primary tumour. Arrest may result from obstruction of a narrow vessel or adhesion to the inner lining of the vessel.

5. Extravasation: tumour cells penetrate the vessel walls and enter the surrounding tissues where they proliferate to form secondary tumours (metastases).

Similar mechanisms, involving the lymphatics, are believed to be involved in spread to regional lymph nodes. 
Tumour metastasis is a rather inefficient process, with less than $0.1 \%$ of circulating cells ultimately surviving to produce a metastatic focus (3). To survive the passage from primary site to distal deposit they must avoid host defences and withstand mechanical turbulence in the circulation. Some form of protective covering is thus required (4). Procoagulants, liberated by tumour cells, activate plasma clotting factors so that the tumour embolus becomes enmeshed in a covering fibrin coat. Platelet deposition adds to the shielding and enlarges the embolus, so favouring terminal lodging and protection from the sheai forces of blood flow.

\section{Site-specific metastasis}

Two theories exist to explain the sites of metastases. According to the "seed and so:l" hypothesis, tumour cells are predisposed to spread to particular tissues on the basis of a propitious interaction between the cells and the tissue in question (5). Others have argued that, although organ-specific metastasis does occur, this could be attributed to routes of blood flow away from the primary tumour (6). Thus tumour cells would arrest in the next downstream capillary bed from the primary site. It would now appear that these theories are not mutually exclusive. Site-specific factors may include growth factors, adhesion molecules and chemotactic molecules.

\section{Invasion}

The process of invasion is a recurrent theme in all considerations of metastasis. Invasiveness describes the ability of cells to cross such anatomical barriers as extracellular matrix, basement membranes and interstitial stroma. Apart from the role of invasion in tumour development, invasive behavior occurs normally during embryogenesis, trophoblast implantation, angiogenesis and extravasation of 
leukocytes in inflammation and wound repair $(7,8)$. While the mechanisms of invasion are likely to be the same for normal and malignant cells, the difference lies in the regulation. Normal invasion stops when the stimulus is removed while malignant cells migrate relentlessly.

Requirements for the tumour cell to traverse the basement membrane are firstly adhesion to basement membrane components via cell surface molecules, followed by localized degradation of basement membrane molecules and then migration into the zone of lysis. Continued invasion would take place by cyclical repetition of these three steps.

\section{Adhesion}

The importance of adhesion in the later stages of metastasis has been illustrated by studies with B16 mouse melanoma cells. Co-injection of B16 cells with the GRGDS peptide, responsible for fibronectin binding to its receptor, inhibited formation of lung colonies (9) and prolonged host survival (10). In addition, a number of studies have illustrated the importance of adhesion molecules in sitespecificity of colonization (11). Tumour cells with different organ-site preferences have been incubated in vitro with endothelial cells isolated from the cultured microvasculature of the various organs. In most cases the tumour cells adhered selectively to endothelial cells derived from their preferred metastatic site (12). Tumour cells may cause endothelial cells to retract, so allowing adherence to the exposed matrix. Similar experiments have indicated preference for adhesion to matrix from the metastatic organ (13). The expression of adhesion molecules on the surface of endothelial cells can be induced by cytokines (tumour necrosis factor, interleukin 1) which may be secreted by the tumour cells (14) and there is 
evidence to indicate that the extracellular matrix (ECM) upon which endothelial cells reside influences the expression of organ specific adhesion molecules (15).

\section{Motility}

Active motility enhances metastatic potential and is a property of most metastatic tumour cells (16). Factors which are chemotactic for tumour cells include fragments of ECM molecules, such as fibronectin and laminin (17-19), which are produced by tumour-derived enzymes.

\section{PROTEASES IMPLICATED IN INVASION AND METASTASIS}

A number of proteases have been implicated in the invasive process. The extracellular matrix consists of collagens, glycoproteins (eg. fibronectin, laminin ), proteoglycans and glycosaminoglycans. ECM-degrading proteases produced by invading cells may be divided into three subtypes:
1) metalloproteases,
2) serine proteases and
3) cysteine proteases.

This review will be confined mostly to the plasminogen activators, however, there is also substantial evidence to suggest that the collagenases play an important role in invasion and metastasis. The metalloproteases include interstitial collagenase and type IV collagenase. These enzymes are secreted in a latent form and require activation by limited proteolysis - usually by serine proteases (20). They are inhibited by specific tissue inhibitors of metalloproteases (TIMPS).

The best characterized serine proteases are the plasminogen activators. The PA's convert the zymogen plasminogen, a ubiquitous plasma protein, to plasmin 
(21). Plasmin plays an important role in controlling hemostasis by degrading fibrin. It has a broad specificity and can degrade several ECM components, including fibronectin, laminin and the core protein of proteoglycans (22). In addition, plasmin may contribute indirectly to extracellular proteolysis by activating certain prometalloproteases (20). Two types of plasminogen activators exist, namely the urokinase type (UPA) and the tissue-type (tPA). Although there is about $40 \%$ structural homology, they have distinct origins and functions $(7,23)$.

\section{Tissue plasminogen activator (tPA)}

The tPA gene is located on chromosome 8 (24) and spans more than $30 \mathrm{~kb}$. The sequence contains fourteen coding regions separated by thirteen introns, and is transcribed into a $2.7 \mathrm{~kb}$ mRNA (25). Mature tPA is a single-chain glycoprotein of 530 amino acids $(70 \mathrm{kD})$ from which a 32 amino acid leader sequence has been removed prior to secretion (26).

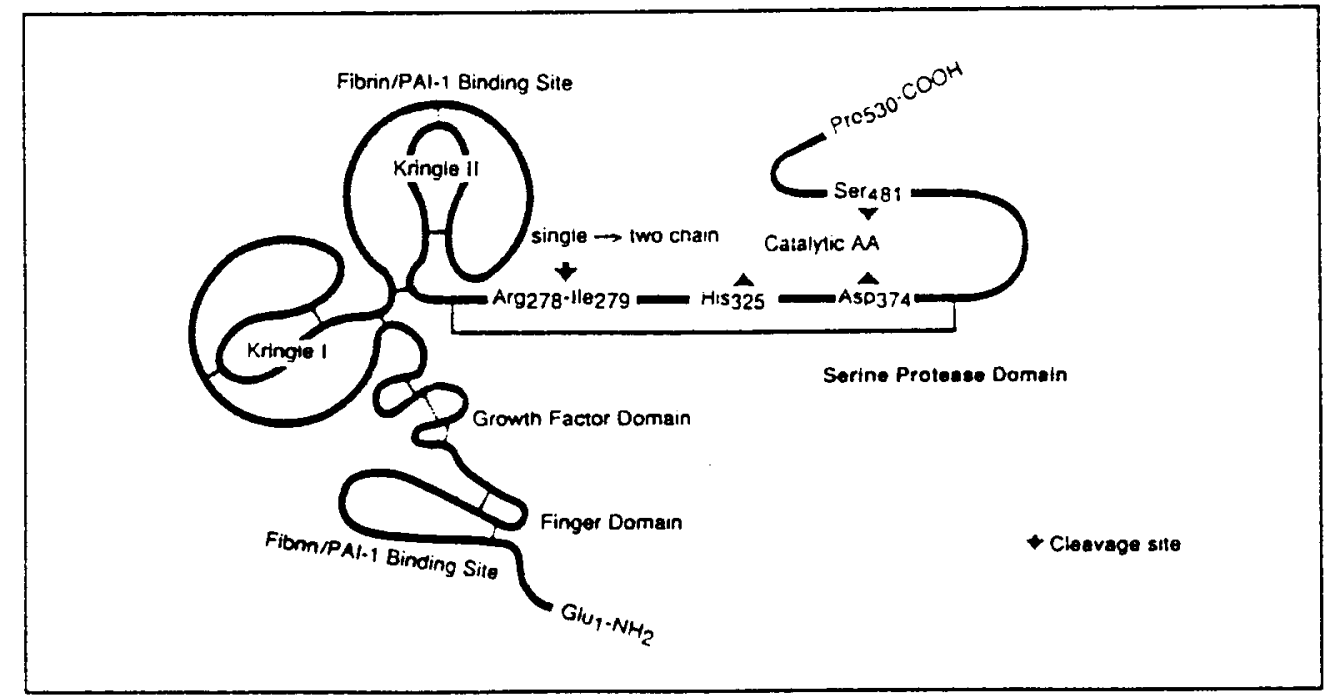

The structure of tissue plasminogen activator

The arrow indicates the cleavage site for the conversion of single chain-tPA to two chain-tPA

(figure reproduced from ref. 137) 
Cleavage of the $\mathrm{Arg}^{278}-11 \mathrm{e}^{279}$ bond by plasmin, tissue kallikrein or factor Xa yields tc-tPA which comprises an $A$ and $B$ chain held together by a disulfide bond. tc-tPA is $10-50$ times more active in the presence of fibrin. The catalytic site is located on the B chain and contains the His, Asp and Ser residues which are characteristic of the active site of all serine proteases (7).

The A chain contains three domains, a cysteine rich "growth factor domain" (residues 54-87) with homology to epidermal growth factor, a domain resembling the "finger" domain of fibronectin, and the "kringle" domain. The latter contains two kringle structures related to those found in prothrombin, plasminogen and factor XII. tPA has a strong affinity for fibrin, imparted by lysine binding sites in the kringles. Because plasminogen also binds to fibrin, colocalization of tPA, plasminogen and fibrin results in a 60-fold decrease of the Michaelis constant for plasminogen activation (7).

tPA is believed to be primarily involved in clot lysis during fibrinolysis. It is produced by, amongst others, vascular endothelial cells, with a normal plasma level of about $5 \mathrm{ng} / \mathrm{ml}$, of which over $95 \%$ is bound to plasminogen activator inhibitor-1 (PAI-1). tPA has a short plasma half-life before being cleared by cells in the liver (23).

\section{tPA Receptor}

Cell surface associated tPA has been reported for a number of cell types including human umbilical vein endothelial cells (HUVEC) (27), human aortic endothelial cells (HAEC) (28), hepatoma cells $(29,30)$ and melanoma cells (31). However a single, well defined receptor such as that for UPA remains to be demonstrated. 
Hajjar et al. identified two binding sites for TPA on HUVEC cells, namely a high affinity $\left(K_{d}=28 \mathrm{pM}\right)$ and low affinity $\left(K_{d}=18 \mathrm{nM}\right)(32)$. Later the same authors further characterized a dual plasminogen-tPA receptor in placental extract (33), which appears to be identical to the low affinity receptor above. The affinity of this $40 \mathrm{kD}$ receptor for $\mathrm{PA}\left(\mathrm{K}_{\mathrm{d}}=30 \mathrm{nM}\right)$ is somewhat higher than for plasminogen $\left(K_{d}=114-120 \mathrm{nM}\right.$ ), in addition lysine binding sites appear to be involved only in the case of plasminogen. This evidence suggests that the receptor expressed on endothelial cells may juxtapose tPA and plasminogen, in such a way as to promote plasmin generation.

Another study involving HUVEC cells provides evidence for two tPA binding sites (34). The high affinity binding site ( $K_{d}$ not determined) was shown to be PAl-1, and binding required the active site of $\mathrm{PAA}$, with subsequent inactivation. Binding to the low affinity site was independent of the catalytic site with a $K_{d}$ of $170 \mathrm{nM}$. These results appear to conflict with those of Hajjar et al., although possibly the low affinity site (34) is equivalent to the tPA-plsg receptor and the PAI-1 site equivalent to the high affinity site described by Hajjar et al. HAEC express a single class of tPA receptors with $K_{d}$ of $1.2 \mathrm{nM}(28)$, it is not clear how this receptor is related to the HUVEC receptors.

In contrast to the endothelial cell receptors discussed above, tPA bound to hepatoma cells $(29,30)$ is rapidly internalized and degraded. These receptors are presumably involved in tPA clearance in the liver.

It is clear from the extensive literature on the subject, that cell surface associated UPA plays a role in invasion of a variety cancer cell types (see 35 for review). A 
notable exception however, is melanoma, since the majority of melanoma cell lines produce only tPA and not UPA $(36,37,38)$. A melanoma tPA receptor would be of interest as it could provide an alternative mechanism for plasminogen activation at the cell surface.

In a recent study, cell surface associated tPA was demonstrated in five tPA producing melanoma cell lines (31). Cell associated tPA was measured by assaying IPA activity in acid eluates of adherent cells, with the implication that IPA could be bound to either the matrix or the cells. Plasminogen activation on the cell surface was demonstrated, and this could be inhibited to anti-catalytic antibodies to tPA. Thus although this study provides some evidence for a melanoma tPA receptor, specific tPA binding to a defined receptor on melanoma cells remains to be demonstrated.

\section{Urokinase plasminogen activator (UPA)}

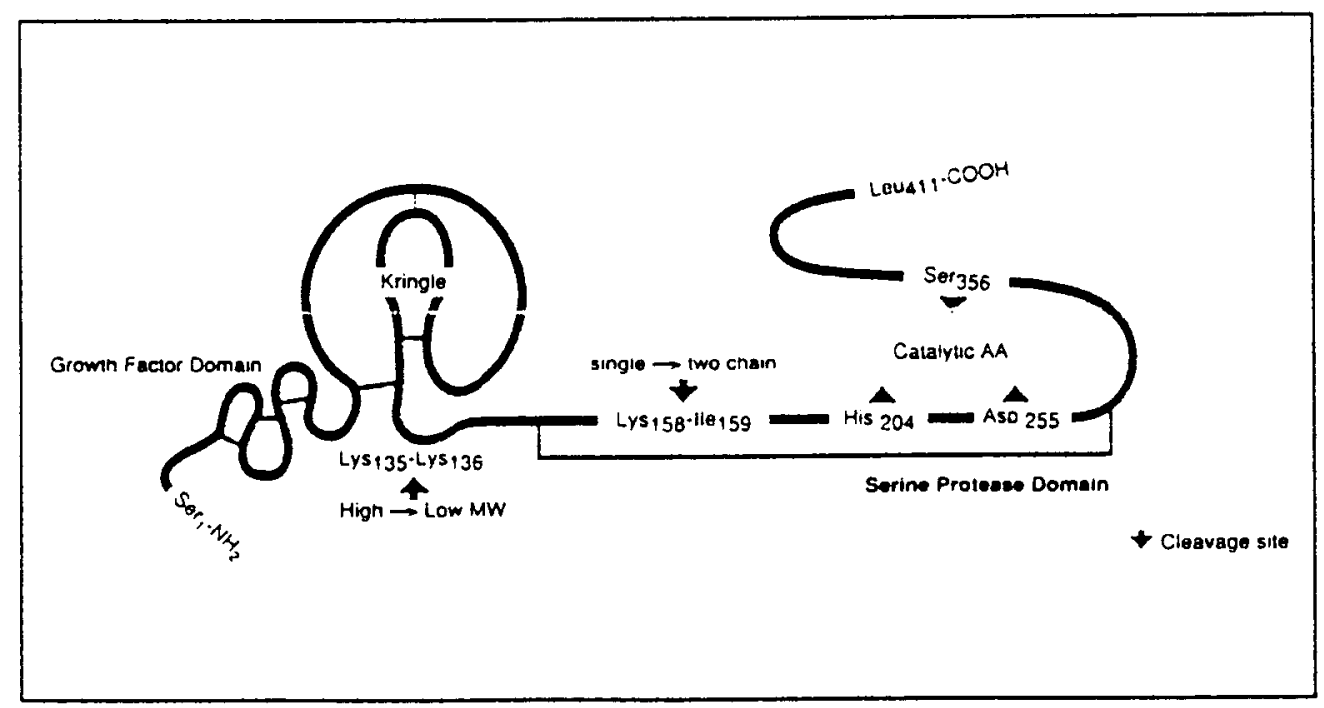

The structure of urokinase plasminogen activator The first arrow indicates the cleavage site for the conversion of HMW UPA to LMW UPA, with the release of the ATF (Lys 135-Lys 136). The second arrow indicates the cleavage site for the conversion of Sc-uPA to tc-uPA (reproduced from ref. 137). 
Urokinase-type PA was first isolated from urine $(39,40)$, from which its name is derived. UPA is secreted as a single chain zymogen of $54 \mathrm{kD}$ (41-43). Digestion by plasmin or tissue kallikrein cleaves SC-UPA into $A$ and $B$ chains which remain attached by a disulfide bridge (44). As in the case of TPA, the B chain contains the catalytic site, and consequently the binding sites for the inhibitors PAI-1 and PAI2.

Similarly to tPA, the A chain of UPA contains both growth factor and kringle domains. However, the single kringle domain of UPA has no lysine binding site and hence lacks affinity for fibrin. The functional significance of the growth factor domain is that it forms the binding site for the cellular receptor for UPA (UPAR) (45). Part of the A chain can be cleaved off, to form the amino terminal fragment (ATF), which contains the growth factor domain, and LMW UPA (33 kD).

Other functions for UPA apart from plasminogen activation have been elucidated. UPA can directly activate procollagenases, independently of plasminogen (46). In addition, UPA has been shown to have a mitogenic effect upon certain cells in culture (47-51). The ATF is required to demonstrate stimulation, since LMW UPA shows no effect. However it remains controversial as to whether or not the intact active enzyme is required (52). Although the mechanism for this stimulatory effect of UPA remains unknown, it may involve signal transduction upon binding of the UPA to the receptor, as in the case of other ligand-receptor systems (eg. 53). Receptor phosphorylation is common to many signal transduction pathways that promote growth and differentiation, and although the UPAR itself is not phosphorylated upon binding UPA, recent evidence indicates that interaction of UPA with its receptor induces tyrosine phosphorylation of an associated $38 \mathrm{kD}$ protein (54). 


\section{UPA receptor}

The cellular receptor for UPA has been well characterized by a number of authors (55-61). The UPAR is expressed as a single chain $55-60 \mathrm{kd}$ glycoprotein $(55,56)$ and is linked to the cell surface via a glycosyl-phosphatidylinositol (GPI) anchor (60). The UPAR binds specifically to both forms of UPA with high affinity $(58,62)$. The number of receptors per cell varies and may be induced by various agents including phorbol 12-myristate 13-acetate (PMA) $(63,64)$.

Binding of UPA to its receptor has a number of important effects. There are numerous low affinity cellular plasminogen binding sites (65) and the conversion of plasminogen to plasmin by SC-UPA is increased 20 -fold when UPA and plasminogen are both localized on the cell surface $(62,65,66)$. In addition the conversion of SC-UPA to tc-UPA by plasmin is increased 50 -fold when it is receptor bound. Receptor bound tc-uPA converts plasminogen to plasmin at a greater rate (62).

Inhibition by PAI- 1 and PAI-2 is decreased by $40 \%$ after UPA has bound to its receptor $(67,68)$. Receptor-bound UPA has been shown to be localized at focal contacts of cells, thus facilitating proteolysis during cell movement $(68,69)$. UPA bound to the receptor remains on the cell surface for several hours, and is not internalized and degraded except when complexed with PAI-1 (58).

UPA has been shown to be capable of cleaving its own receptor (70), generating a cell-associated form incapable of ligand binding. Binding of UPA to the receptor is not required, since LMW UPA is also capable of cleavage. This reaction may represent a further mechanism for regulation of plasminogen activation. 


\section{Regulation of plasminogen activators}

The expression of PA activity is controlled at three levels.

1) gene transcription: Expression of PA is controlled at the transcriptional level by a number of agents, including tumour promoters, oncogenes and growth factors (70).

2) proenzyme activation (as described above)

3) inhibition by specific inhibitors (discussed below)

Inhibitors: PAI-1 (endothelial type) is an approximately $50 \mathrm{kD}$ glycoprotein which is produced by a variety of cell types and is also present in plasma (72). Two PAI1 mRNA species exist ( 2.3 and $3.2 \mathrm{~kb}$ ) which, due to alternative polyadenylation, differ only in the length of the 3 ' untranslated region (73). PAl-1 is unstable when secreted and becomes latent, unless stabilized by binding to vitronectin in the ECM (74). Latent PAI-1 can be reactivated in vitro by treatment with denaturants, such as guanidine, urea and SDS. PAl-1 inhibits the two chain forms of TPA and UPA, rapidly forming 1:1 molar complexes, however it has poor affinity for the single chain forms.

Other PA inhibitors include PAI-2 (placental type) and protease nexin 1. PAI-2 inhibits tc-UPA tenfold more efficiently than tc-tPA, and has little effect on the single chain forms (75). Protease nexin was originally purified from cultured fibroblasts and is an inhibitor of thrombin, plasmin, trypsin and uPA (76). 


\section{EVIDENCE FOR INVOLVEMENT OF PROTEASES IN METASTASIS}

There is a substantial body of evidence which suggests that proteases play a crucial role in invasion and metastasis of tumor cells (see 77-79 for reviews). Three lines of evidence supporting this view are discussed below:

\section{Proteases are involved in normal tissue remodelling}

In order for tumour cells to invade and metastasize, they are required to breach micro-environmental barriers such as the basement membrane (BM). This disruption of the BM is one of the main criteria for assessing tumour malignancy. Proteases, including the PA's, are involved in normal physiological processes where tissue destruction and remodelling occurs (eg. angiogenesis, inflammation, trophoblast implantation and wound repair) $(7,8)$, thus it seems likely that they may play a similar role in cancer cell invasion. Increased expression of proteases is widely considered to be a property of malignant transformation (7).

\section{Correlation between protease activity and metastatic potential of various tumours}

Indirect evidence for the involvement of PA in tumour invasion and metastasis has been provided by numerous studies showing increased levels of proteases in malignant tissue compared to normal or benign tissue. Increased levels of UPA and PAI-1 in breast carcinoma as compared to benign levels has been associated with a higher relapse rate, whereas IPA appears to be a favorable prognostic marker (80-86). Increased uPA antigen has been reported in colon carcinoma as compared with normal tissue $(87,88)$. Immunocytochemistry of primary and metastatic tumours of pulmonary adenocarcinoma showed higher frequency of UPA positive cells in metastatic lesions than in primary ones. In addition, the 
prognostic markers for cancer, however they fail to provide direct evidence for the role of proteases in invasion and metastasis.

Positive correlations between protease activity and invasive potential may also be observed in model cell lines. For example, sublines of B16 mouse melanoma cells are often used for metastatic studies in the mouse. In two of these sublines, $\mathrm{B} 16_{\mathrm{F} 10}$ which is highly metastatic; and $\mathrm{B} 16_{\mathrm{F} 1}$ which seldom metastasizes to the lung, the levels of PA have been shown to correlate with this metastatic potential (90).

In another study of this type, Quax et al. (91) examined five melanoma cell lines, all of which produced tPA and UPAR and only two produced UPA, were examined in vitro and in vivo. All five melanomas showed plasmin-dependent degradation of smooth muscle ECM, although the uPA-producing lines were more invasive. After subcutaneous injection into nude mice, all of the lines developed primary tumours. A correlation was shown between UPA and PAI-1 production and spontaneous metastasis in nude mice. However no correlation was shown between UPA and PAl-1 and lung colonization following intravenous inoculation, with all lines producing colonies with a frequency $>50 \%$. This would indicate a critical role for UPA in intravasation.

\section{Experimental approaches using model systems}

Experiments designed to demonstrate a role for proteases in metastasis have been the focus of much interest in recent years. Most of these studies involve the manipulation of protease activity (via the use of protease inhibitors, antibodies, transfections etc.) using both in vitro and in vivo models for invasion/metastasis. 


\section{Experimental models available:}

In order to determine whether or not proteases are involved in the invasion of tumour cells, suitable in vitro and in vivo models are required. Models currently available for studying tumour invasion and metastasis include:

Degradation of labelled ECM components (eg. laminin, fibronectin), metabolically labelled ECM from cultured cells and matrigel (reconstituted ECM). ECM component studies allow one to investigate degradation of individual substrates although this is far removed from the real situation. The higher complexity of matrigel and cultured ECM makes them realistic substrates, although it should be remembered that ECM composition varies among cell types and may be influenced in vivo by surrounding cells (77).

Natural basement membranes (eg. human amniotic membrane, chorioallantoic membrane, bovine lens capsule) are often used for in vitro invasion studies. There is good correlation between invasion of the amniotic membrane and in vivo metastasis (92). Studies based on these models may be more relevant, however they tend to be technically difficult due to low basal invasion rates and poor reproducibility.

In vivo assays are usually the models of choice; these include invasion of CAM and metastasis formation in the embryo lung and invasion and metastasis following subcutaneous injection or organ colonization following intravenous injection of athymic mice.

Metastatic assays in the chick embryo are relatively inexpensive, sensitive and quantitative, but the composition of the chorioallantoic membrane (CAM) may 
differ from the relevant human basement membrane. Spontaneous metastasis experiments in athymic mice are expensive, lengthy and microscopic metastases are difficult to quantitate. In addition, tumour to host size is usually much larger in experimental animals than in humans where undetectable tumours often metastasize (77).

Enumeration of lung colonization after i.v. injection of athymic mice is useful as it enables investigation only of the later stages of metastasis, however the release of huge numbers of tumour cells into the circulation does not resemble the real situation where only very few cells enter the circulation. There is also a need for assays which measure involvement in only the earlier steps of metastasis (77).

Clearly an ideal model for tumour invasion does not exist and thus a number of different approaches may be required to elucidate the role of proteases in invasion.

\section{In vitro studies}

Many of the recent in vitro studies have focused on the role of UPA and the UPAR in invasion and metastasis. Human colon carcinoma cell lines with varying UPA binding capabilities were used in ECM invasion studies by Hollas et al. (93). GEO colon carcinoma cells which express low levels of UPA and UPAR were poorly invasive in the matrigel assay. Their invasiveness did not increase after transfection with the human UPA gene and subsequent eight-fold increase in UPA secretion. In contrast, the HCT116 colon carcinoma cell line which has many UPAR molecules, all of which are saturated with uPA was highly invasive. This invasion was reduced by an antibody to the A chain of UPA which inhibits UPAUPAR binding. RKO colon carcinoma cells which have large numbers of 
receptors which are not occupied due to low levels of endogenous UPA were poorly invasive, however pretreatment of the RKO cells with UPA resulted in increased receptor bound UPA and consequent increased invasion. Thus, for these colon carcinoma cells it appears that receptor bound UPA is essential for invasion.

HT29 colon carcinoma cells express uPA receptors but no uPA. The cells were transfected with human UPA CDNA and the invasion of R22 smooth muscle ECM compared with that of the parental cells (94). Invasiveness was increased from below detection up to $15 \%$. This increase in invasive ability was inhibited by anticatalytic antibodies to UPA, aprotinin and to a lesser degree by UPAR binding peptide and anti-uPAR antibodies. Thus, these results too indicate an important role for UPAR-mediated degradation.

The work of Ossowski et al. confirms the importance of UPAR-mediated invasion $(95,96)$. In the first study (95), invasion of human tumor cells was reduced by the inhibition of tumor UPA. UPA was also added in order to saturate the receptors, with the result that invasion was increased. In a later study using the same model, mouse tumor cells were transfected with either human uPA or UPAR DNA. Coculturing and inoculation of both cell types onto the CAM resulted in a 4-fold stimulation of invasion, compared to either type alone. This again highlighted the importance of the UPAR in invasion, as well as illustrating that UPA can bind to the receptor in a paracrine fashion.

It is possible that this scenario could also occur in vivo, with UPAR-bearing, malignant cells binding uPA from surrounding stromal cells. Further support for this theory comes from the work of Pyke et al. (97), who did in situ hybridization of 
adenocarcinomas for UPA and UPAR mRNA. UPAR was detected in malignant cells at the periphery of tumours, while UPA mRNA was present only in stromal cells adjacent to the tumour.

Quantitative proteolytic requirements: The amount of PA produced as well as the type may be important for invasion, as was shown by Tsuboi et al. (98). Bowes melanoma, HT1080 fibrosarcoma and Osmond hypernephroma cells were tested in the amnion invasion assay. Bowes which secretes large amounts of tPA, was poorly invasive, as was HT1080 which produces large amounts of UPA, however Osmond which produces low amounts of UPA, was highly invasive. Further elucidation was obtained by addition of antibodies to UPA, TPA and TIMP and plasmin inhibitors. Feduction of Bowes tPA activity by $\alpha$-tPA antibody increased invasion and inhibition of HT1080 uPA by $\alpha$-UPA antibodies had a similar effect. Invasion was also increased in Bowes and HT1080 cells by plasmin inhibitors. Invasion of Osmond cells was blocked by $\alpha$-UPA and plasmin inhibitor. The authors suggested that only a minimal level of plasminogen activation was required for invasion and levels greater than this could cause uncontrolled ECM degradation and interfere with matrix-cell contact.

Concerted proteolytic activities: There is evidence that different proteases may act in concert during matrix degradation (99). The M24met human melanoma (highly metastatic) was tested for degradation of various matrix components and types. Inhibition of degradation by TIMP-2 and PAI-2 was tested. Results showed that UPA degraded primarily glycoproteins in the matrix and that this was a rate limiting step. Metalloprotease mediated degradation of collagens occurred only after removal of these protective glycoproteins. In addition they showed that UPA or plasmin was not required for activation of metalloproteases. 
Another recent study suggests a dual role for UPA and collagenase in invasion (100). The HEp3 (hepatoma) cell line loses invasive ability with sequentia! passage in culture and the loss was correlated with a reduction of interstitial collagenase levels, although uPA levels remained high. In addition, six squamous carcinoma cell lines were tested for UPA levels and invasive ability on the CAM. All cell lines produced high levels of UPA, yet not all were invasive. Levels of collagenase were then investigated and a correlation was shown between interstitial collagenase and invasion. It would have been interesting if uPA inhibition studies had been included to test for absolute requirement of UPA.

As can be seen from the majority of the literature, the picture which emerges is that of UPAR-bound UPA being largely responsible for invasion in a large variety of tumour cells. However, the case of human melanoma cells appears to be different since many highly metastatic melanoma cells produce only tPA and not UPA (36-38).

A role for TPA in the invasion of melanoma was suggested by Meissauer et al. (101). Two melanoma cell lines producing tPA alone (MeWo) and tPA, UPA (cell assoc.) and PAl-1 (Mel Juso) were assayed for degradation of fibrin, matrigel and ECM in the presence of antibodies to UPA and TPA and aprotinin (101). Aprotinin decreased invasion by both cell lines, as did $\alpha$-tPA in MeWo and $\alpha$-UPA in Mel Juso, the ineffectiveness of $\alpha$-tPA in inhibiting invasion of Mel Juso may be explained by free tPA being inhibited by PAI-1, whilst UPAR-bound UPA is protected. Invasion was only partly plasmin-dependent This suggests a role for tPA as well as UPA in in vitro invasion. However, in a later paper (102) the same 
authors show that plasminogen is activated on the cell surface much more efficiently by uPAR-bound UPA (Mel Juso) than by secreted tPA (MeWo).

\section{In vivo studies}

Ossowski and Reich (103) showed in an early experiment using HEp3 cells in the chick embryo metastasis assay that an inhibitory antibody to uPA inhibited invasion and metastasis, but not growth of the primary tumour. Organ colonization, following intravenous injection of Hep3 cells was not inhibited by treatment with $\alpha$-UPA. They were thus able to pinpoint the involvement of UPA to the stage of intravasation. These experiments were the first to illustrate the role of UPA in metastasis in an in vivo model.

In a later study (104) Ossowski used labelled HEp3 cells in the CAM system to investigate the role of UPA in the individual steps of metastasis. Inoculation of HEp3 cells whose uPA activity was inhibited, resulted in 4-fold fewer tumor cells in the embryo organs. Since inhibition of uPA had no effect on either extravasation (shown by i.v. inoculation) of invasion through the CAM; there is indirect evidence that UPA is required for intravasation.

Similar studies using HEp3 cells were extended to the nude mouse model (105). Mice were subcutaneously inoculated with $\mathrm{HEP} 3$ cells and then treated daily with injections of $\alpha$-UPA antibody. Tumors larger than $1 \mathrm{~g}$ were excised and lungs were examined for metastases. Local invasion was inhibited compared to the controls, however metatasis was not reduced. The authors suggeted that this may reflect spread by a tumor protease-independent mechanism, arising from the pronounced granulocytosis caused by the HEp3 cells. 
As mentioned previously, B16 mouse melanoma clones with varying metastatic potential have been useful models for studying metastasis. B16 $\mathrm{F}_{1}$ cells express UPAR but produce low amounts of UPA and are poorly metastatic. B16 $\mathrm{F}_{10}$ cells express UPAR (106) and higher levels of UPA and are highly metastatic. B16 $\mathrm{F}_{1}$ cells were transfected with cDNA for human UPA (107). The UPA produced by transfected cells was not glycosylated and did not bind to the murine receptor. An increase of $200-1760 \%$ was noted in the lung colonization assay for a clone of uPA-transfected $\mathrm{B} 16_{\mathrm{F} 1}$ cells as compared to untransfected controls. In addition spontaneous metastasis increased from $18 \%$ to $100 \%$ of mice injected. This indicates a role for non-surface associated UPA in extravasation, although one cannot draw any conclusions about involvement in the earlier stages. In the same study, B16 $F_{10}$ cells were transfected with antisense human uPA cDNA resulting in a $30 \%$ decrease in uPA activity. These transfectants exhibited a similar decrease in lung colonies compared to the control. Spontaneous metastasis was not tested. These results indicate that the difference in metastatic potential between $B 16_{F 1}$ and $B 16_{F 10}$ is due to the difference in levels of UPA produced and that secreted UPA plays a role in both intravasation and extravasation.

In another study, B16 $\mathrm{F} 10_{0}$ cells were pre-incubated with anticatalytic antibodies to UPA prior to i.v. inoculation of mice (106), with the result that colonization was inhibited by $60 \%$ compared to controls. Pre-incubation with plasmin increased lung colonization by $200-300 \%$. In agreement with the B16 study by Quax et al. (91), the implication is that UPA is involved in extravasation and the events which follow. The remaining colonizing capacity which was not inhibited by $\alpha$-uPA may reflect a subpopulation of cells using different proteolytic mechanisms. This study illustrates one of the limitations of this assay, in that extremely variable results are obtained between experiments. These studies on B16 melanomas, although in 
agreement with each other, contrast with those of Ossowski et al. which implicate UPA in intravasation only.

Both UPA and tPA were implicated in invasion and extravasation by Axelrod et al. (108). Expression of PA's transfected into H-ras-transformed NIH 3 T3 cells resulted in increased invasion of ECM and higher incidence of lung colonization after i.v. injection of mice. The role of PA's was corroborated by inhibition of invasion and colonization by $\alpha$-uPA and $\alpha$-tPA antibodies.

These numerous reports do seem to indicate a role, primarily for receptor-bound UPA and possibly less for TPA, in invasion and metastasis of a wide range of different cancer cell types. Disparity between different reports may be due in part to the complexity of the metastatic process, also to the range of cell types studied, each of which may employ different proteolytic mechanisms for invasion. For example the two independent studies using B16 melanoma are in agreement, although the findings are in contrast to other studies using different cells. In addition participation of more than one proteolytic system may be required, as shown in (99). Another factor to consider, especially for correlative studies is the heterogeneity of tumour populations, and results obtained for the parental population may not apply to the small fraction of metastatic cells.

When considering in vivo studies, it is possible that the spectrum of proteases released by the tumour cells when in the host may be different to in vitro due to interactions with host factors. Several observations indicate that paracrine or autocrine growth factors, as well as tumour-host interactions, can modulate the expression of proteases involved in tumour invasion and metastasis (109-111). 
Some of the more important points to emerge from these studies may be summarized as follows:

- Invasion is most effective when proteolysis is focused on the cell surface, rather than in the soluble phase (eg. 93).

- PA's and metalloproteases appear to act in concert, forming a cascade of proteolysis (eg. 99, 100)

- Indiscriminate proteolysis does not necessarily favour invasion (eg. 98), rather fine modulation is required, indicating a role for the inhibitors (eg. PAI-1, TIMP)

Recent evidence indicates a further role for proteases, particularly the PA's, in the modulation of tumour angiogenesis by:

1. The release of matrix-associated basic fibroblast growth factor (bFGF) into the soluble phase.

2. The activation of latent transforming growth factor $-\beta$ (TGF- $\beta$ ).

Both of these factors are potent inducers of angiogenesis. In contrast to the process of tumour invasion, however, this proteolysis is finely controlled. Plasmin has been shown to release bFGF from the matrix (112), which stimulates PA and collagenase expression by vascular endothelial cells. This process is balanced by the effect of TGF- $\beta$, which down regulates protease expression and stimulates production of inhibitors (77). Once the active TGF- $\beta$ is depleted, the production of proteases increases. Thus, the process of angiogenesis results from a series of cyclical phases of proteolysis and inhibition thereof.

The question of whether fibrinolysis favours or inhibits tumour dissemination is an ongoing one. On the one hand proteolysis, particularly plasminogen activation is clearly important for intra- and extravasation. On the other, deposition of fibrin on 
the tumour embolus is thought to prevent destruction and favour lodgement, and there is evidence for involvement of PAI-1. Most likely a delicate balance of coagulation and fibrinolysis is involved. 


\section{PART 1}

Expression of plasminogen activators, UPAR and PAI-1 in UCT-Mel 3 cells

\section{Introduction}

Most human melanoma cell lines are known to release only tPA enzyme activity and no uPA activity (36-38). UCT-Mel 3 is no exception to this general rule. Hoal et al (36), using high affinity antibodies to IPA and UPA showed that all enzyme activity could be abolished by the former and none by the latter. Similarly, electrophoretic analysis with subsequent zymography and immunochemical inactivation has consistently shown that UCT-Mel 3 cells release only IPA and no detectable uPA.

A growing body of opinion has come to suggest that UPA, bound in a functional state to its cell-surface receptor, plays a major role in the metastatic process (35). Indeed, Quax et al. (91) have produced data to indicate that only melanoma cells that released UPA were metastatic; IPA alone was insufficient to serve this process. Since UCT-Mel 3-derived tumors are consistently invasive and metastatic in the nude mouse and since the previous studies I have referred to failed to demonstrate UPA release by UCT-Mel 3 cultures, I felt it would be of interest to document this negative association more conclusively. I thus repeated experiments to define the nature of the PA released by UCT-Mel 3 cells. The absence of UPA release would thus tend to contradict the view that UPA was essential.

It should, however, be remembered that, like most cultured melanoma cells, UCTMel 3 cells could be expected to be clonally unstable. It was conceivable, therefore, that within the primary tumor, mutants might arise that would express 
uPA and that it was these that invaded and metastasized. For them to do so, they would, according to current theory, require uPA receptor. Furthermore, their invasive and metastatic potential would be enhanced if they failed to release the potent PA inhibitor, PAI-1. I therefore examined metastatic deposits for UPA release and both metastases and the parent line for evidence of UPA receptor and PAl-1 synthesis

Despite the fact that cultured melanoma cells and other malignant cell lines are known to differ qualitatively in their patterns of PA release (113) few attempts have been made to explain this difference, and little has been done to clarify the possible role of plasminogen activator inhibitors in determining the spectrum of proteases released by melanoma cells. This information was clearly of relevance to the theme of this thesis, so I undertook in addition, a series of experiments that were designed to provide an answer to the following question: Does the lack of UPA reflect a change in transcription, translation or a more profound change in the genome?

If it should prove to be the case that the relative release of UPA and IPA showed a consistent pattern in melanoma cells, and moreover, if this pattern could be consistently explained by a common genetic mechanism, this would constitute an important descriptive contribution to our knowledge of a serious malignant disorder.

In this chapter I describe the results of the experiments in which I addressed some of these questions. 
Materials and Methods

\section{Antibody purification}

Polyclonal sheep antibodies that specifically inhibited either UPA or IPA were obtained from animals that had been immunized with preparations that were enzymatically pure (114). The immune sheep serum was purified by caprylic acid precipitation (115) as described (A.15).

\section{Fibrin plate assay for PA activity}

Serum-free conditioned medium from the UCT-Mel 3 cell line was tested in this assay as described in the appendix (A.7). The PA type was determined by incubating samples with inhibitory antibodies to UPA and tPA before assaying.

Electrophoretic and zymographic analysis (95, with modification) Conditioned media and cell lysates were electrophoresed in $12 \%$ polyacrylamide gels alongside known tPA (20 $\mu$ Bowes conditioned medium) and UPA (1.25 $\mathrm{mU} / \mathrm{ml}$ ) standards. Electrophoretically resolved bands of plasminogen activator activity were detected by washing the gels in detergent (to remove SDS) and then overlaying them with a layer of agarose containing casein and plasminogen (A.14). Immunochemical identification of PA type was achieved by incorporating either $\alpha$-tPA or $\alpha$-UPA antibodies into duplicate overlays.

\section{RNA Extraction and Northern Blot analysis}

Cells growing as adherent monolayers were released with trypsin and their RNA was extracted using the one step Guanidinium Thiocyanate procedure (A.8). As a positive control for detecting mRNA transcripts for UPA, UPAR and PAI-1, I used RNA from the breast fibrosarcoma cell line, HT1080 (116). A probe for $\beta$-Actin was hybridized to stripped blots to control for equal loading of lanes (117). 
The RNA was electrophoresed in a formaldehyde/agarose gel (A.9) and the gel was treated and blotted according to the standard procedure described in the appendix (A.10)

CDNA clones of the IPA, UPA, PAI-1, UPAR and $\beta$-actin genes were used as probes (table 1.1). The fragments were purified by electrophoresis in low melting point agarose gels (A.11). Approximately $50 \mathrm{ng}$ of each probe was random prime labelled with $50 \mu \mathrm{Ci}$ of $\alpha$-32P dCTP.

Table 1.1 Details of CDNA probes

\begin{tabular}{|l|l|l|l|c|}
\hline CDNA probe (1) & plasmid (2) & enzyme digest (3) & size (4) & ref. \\
\hline UPA & pSP64RUK & EcoRI+HindIII & $600 \mathrm{bp}$ & 118 \\
tPA & pW349F & BglII & $2000 \mathrm{bp}$ & 119 \\
PAI-1 & PAI-1/pGEM3 & ECORI & $2944 \mathrm{bp}$ & 120 \\
UPAR & uPAR/pEMBL & BamHI & $660 \mathrm{bp}$ & 55 \\
b-actin & pHFbA-1 & BamHI & $1900 \mathrm{bp}$ & 117 \\
\hline
\end{tabular}

(1) sequence coded by cDNA

(2) name of plasmid from which cDNA insert was excised

(3) restriction enzyme/s used to excise insert

(4) size of insert in base pairs

Blots were pre hybridized for $2 \mathrm{hr}$ at $42^{\circ} \mathrm{C}$ before adding the freshly denatured, labelled probe. After hybridizing overnight the blots were washed twice in 2x SSC, $0.1 \%$ SDS for $15 \mathrm{~min}$ at room temperature and twice in $0.1 \times$ SSC, $0.1 \%$ SDS for 15 min at $42^{\circ} \mathrm{C}$. Damp blots were sealed in plastic and exposed to $x$-ray film. 


\section{Culture of metastases}

Metastases were dissected from nude mice bearing UCT-Mel 3 derived subcutaneous primary tumours (121). The metastatic fragments were minced and dissociated by stirring with $0.25 \%$ Trypsin. The cell suspension was centrifuged and the cell pellet plated in RPMI containing 10\% FCS (RP10). Adherent cells were serially passaged 4 times to yield pure cultures of metastatic human melanoma cells. Chromosome spreads of the metastatic cells were prepared (A.21) and examined in order to confirm their human origin.

\section{Measurement of PA in cultured metastases}

Both metastatic and parent UCT-Mel 3 cells were plated, in triplicate; at densities of $10^{5}, 2 \times 10^{5}$ and $10^{6}$ cells $/ 60 \mathrm{~mm}$ dish. Conditioned media were collected as described (A.18) and assayed in the fibrin plate assay for PA activity.

\section{Southern blot analysis}

Genomic DNA analysis: Genomic DNA was isolated as described (A.12) and digested with EcoRI and HindIII. $10 \mu \mathrm{g} /$ lane of each digest was electrophoresed overnight on a $1 \%$ agarose gel and the gel was treated and blotted as described (A.13). Blots were prehybridized at $68^{\circ} \mathrm{C}$ for $2 \mathrm{hr}$ and then hybridized to the freshly denatured labelled probe overnight. They were then washed twice in $2 x$ SSC, $0.1 \%$ SDS for $15 \mathrm{~min}$ at room temperature and then twice in $0.1 \times$ SSC, $0.1 \%$ SDS at $68^{\circ} \mathrm{C}$ for $15 \mathrm{~min}$. Damp membranes were sealed in plastic wrap and exposed to $\mathrm{x}$-ray film.

\section{PAI-1 ELISA}

Conditioned media collected from UCT-Mel 3 cells and cells cultured from metastatic deposits were concentrated 10-fold using a centricon 
microconcentator (Amicon) and then tested for the presence of PAl-1 antigen with an ELISA kit (American Diagnostica).

\section{Binding studies to demonstrate UPAR}

It is known that residues 3-135 of UPA (the amino terminal fragment; ATF) contains the binding site for the cell-surface uPA receptor (44). ATF, (a kind gift from Jack Henkin, Abbott Laboratories, Illinois) was labelled and used as a ligand to quantitate and characterize cell-surface UPAR.

Receptors were stripped of UPA by acid treatment before performing all binding experiments (A.32). ATF (10 $\mu \mathrm{g}$ ) was iodinated by the lodogen method (see A.20) using $250 \mu \mathrm{Ci}$ of ${ }^{125}(50 \mu \mathrm{M})$. Two procedures were used to check the integrity of the labelled product. In the first, 0.4 pmoles of ${ }^{225}$-ATF were electrophoresed on a $12 \%$ SDS polyacrylamide gel, the gel was dried and then autoradiographed overnight to give the result shown in fig. 1.1. A single radioactive band, with a $M_{r}$ appropriate for ATF was observed. By this criterion, therefore, the labelled ATF was physically intact.

In the second procedure, the functional integrity of the labelled peptide was assessed by quantitating the amount of radioactivity that was bound by a saturating concentration of cells that are known to express UPAR. In this assay a fixed concentration of labelled ATF (1 nM) was incubated for $2 \mathrm{hr}$ at $4^{\circ} \mathrm{C}$ with various numbers $\left(1.3 \times 10^{5}-10^{6}\right)$ of U937 cells suspended in $200 \mu$ of HEPES buffered RPMI containing $0.5 \% \mathrm{BSA}$. The cell suspensions were then carefully layered onto $500 \mu \mathrm{l}$ of FCS in a microfuge tube and centrifuged $\left(400 \mathrm{~g}, 4^{\circ} \mathrm{C}\right)$ to separate cell-bound radioactivity (in the pellet) from free ${ }^{125}$-ATF (in the supernatant above the FCS layer). The supernatant was aspirated and bound ligand was measured by counting the tubes in a $\gamma$-counter. 
The reciprocal of the bound radioactivity was plotted as a function of the reciprocal of the cell number to yield the plot shown in fig. 1.2. Extrapolation to the ordinate axis (corresponding to an infinite cell concentration) showed that $25 \%$ (declining with storage of the ATF) was functionally intact in the sense that it was capable of binding to the uPA receptor. Thus, for all subsequent binding experiments the concentration of labelled ATF added (b) was taken to represent $0.25 \times b$ that was capable of binding to UPAR.

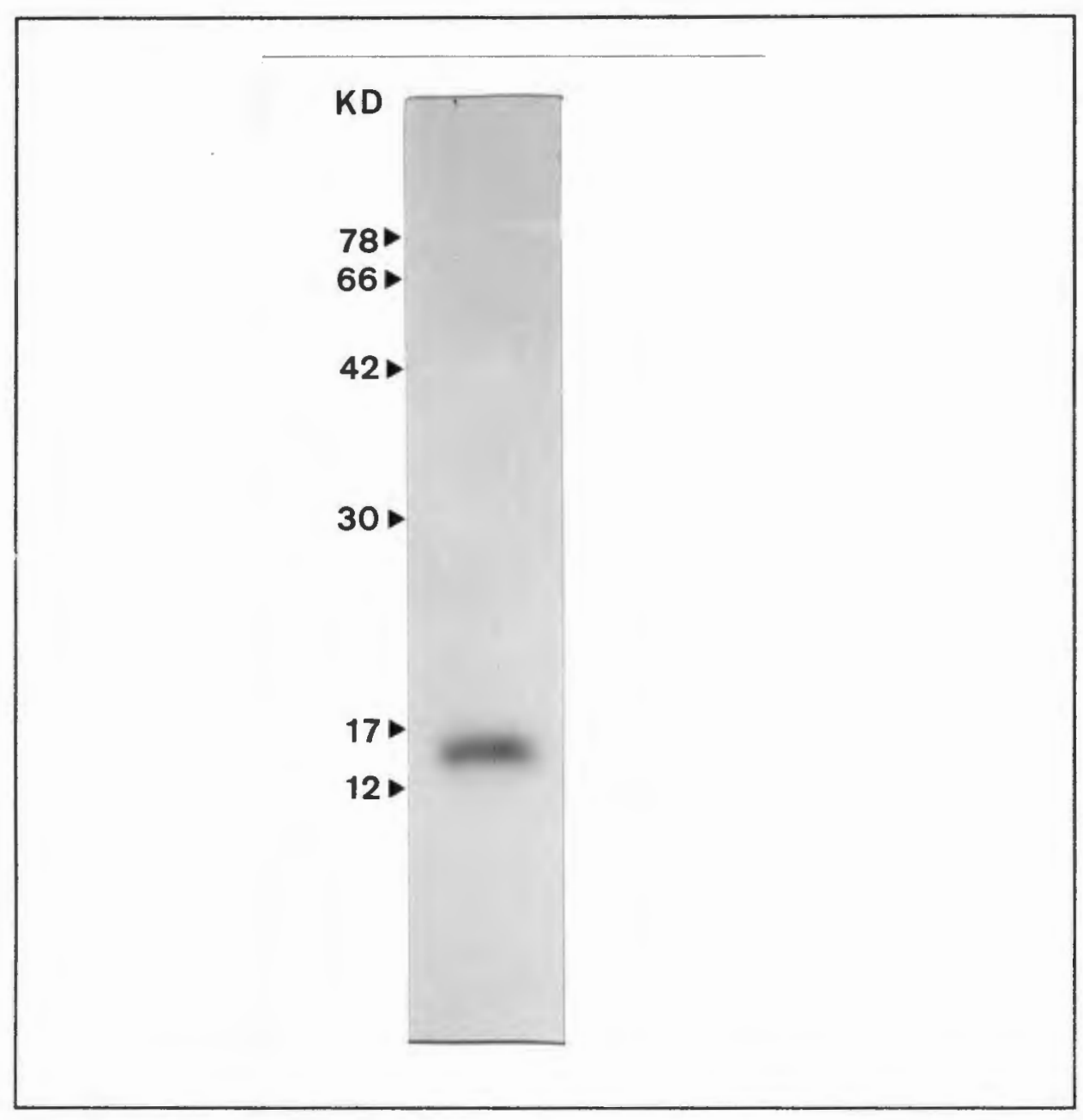

Figure 1.1

SDS PAGE with subsequent autoradiography of 125-labelled ATF ATF was iodinated using the iodogen method and then 0.4 pmoles were electrophoresed on a $12 \%$ polyacrylamide gel. The gel was dried and autoradiographed overnight. The mobilities of molecular weight standards are indicated, from which the size of the labelled ATF was calculated to be approximately $14 \mathrm{kD}$. 


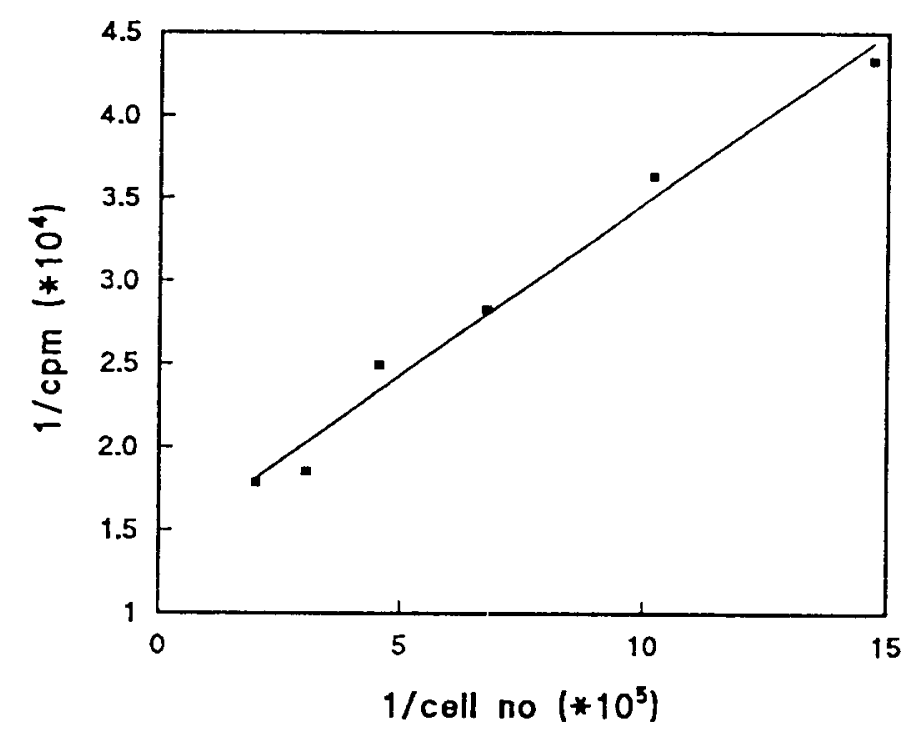

\section{Figure 1.2}

Double reciprocal plot of ATF binding to U937 cells

$1 \mathrm{nM}{ }^{125}$ /-labelled ATF was incubated with various numbers of U937 cells for $2 \mathrm{hr}$ at $4^{\circ} \mathrm{C}$. Unbound radioactivity was removed by spinning cells through a cushion of FCS, and the reciprocal of bound counts per min were plotted as a function of the reciprocal of cell number. Extrapolation to the ordinate axis showed that 7151 $\mathrm{cpm}$ of the total $28755 \mathrm{cpm}$ added were able to bind to an infinite concentration of cells, corresponding to $25 \%$ of functionally active $125 !$-ATF.

Regression parameters for $y=m x+c: m=0.207, c=1.398, r=0.992$

Binding of 125 I-labelled ATF to U937 and UCT-Mel 3 cells was measured essentially as described above, save for the obvious fact that, in these experiments, the number of cells was kept constant $\left(10^{6}\right.$ cells $\left./ 200 \mu l\right)$ and the amount of ATF present was varied. In each of the first series of binding assays a constant amount of radioactivity ( $0.25 \mathrm{nM}$ of functional 125I-ATF) was diluted with different amounts of non-radioactive ATF in order to compete for the binding of 125I-ATF.

In the second series of experiments planned to generate Scatchard plots, doubling dilutions of $(10 \mathrm{nM}$ ) functionally intact radioactive ATF (measured as 
above) were added to U937 or UCT-Mel 3 cells in the absence (specific binding) or presence (non-specific binding) of a 100-fold excess of non-radioactive ATF. Tubes were incubated and processed as described to give values for bound and free ATF that were used for the analysis.

$\underline{\text { Results }}$

\section{Plasminogen activator synthesis by UCT-Mel 3 cells}

Plasminogen activator activity released by UCT-Mel 3 cells, and measured as the plasminogen-dependent release of 125 -labelled fibrin, was inhibited by anti-tPA antibody but not by anti-uPA antibody (fig. 1.3).

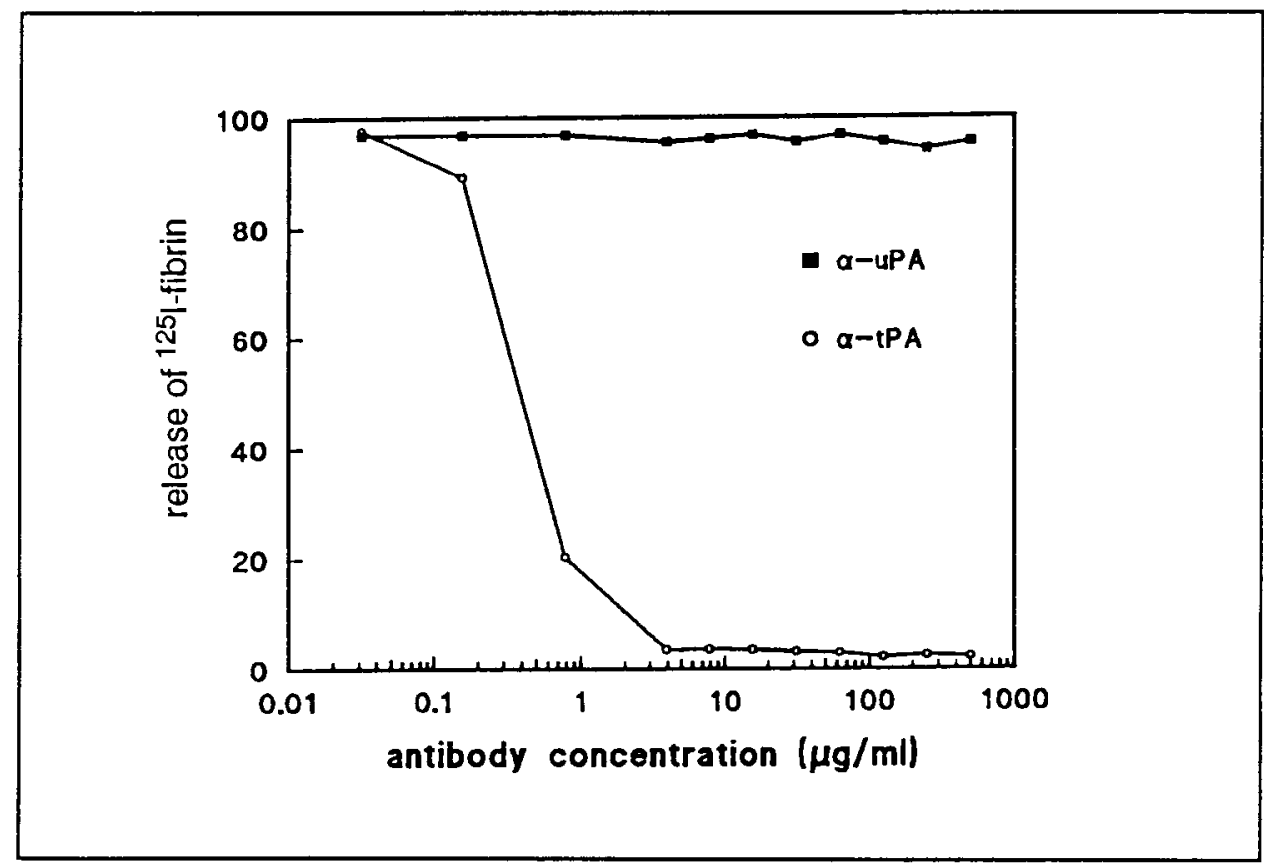

Figure 1.3

Antibody titration of UCT-Mel 3 harvest fluid in the $125 \mid$-fibrin plate assay Neat UCT-Mel 3 ( $10^{6}$ cells $/ 60 \mathrm{~mm}$ dish) harvest fluid was incubated with an equal volume of buffer or serial dilutions of $\alpha$-tPA or $\alpha$-uPA polyclonal antibodies and incubated at $4^{\circ} \mathrm{C}$ for $1 \mathrm{hr}$. $80 \mu \mathrm{l}$ of each sample was then assayed in the ${ }^{125}$ |-fibrin plate assay as described (A.7), results were plotted as \% of control (no antibody added) as a function of antibody concentration. 
Zymography of electrophoresed plasminogen activator synthesized by UCT-Mel 3 cells showed that, by the criterion of size (main band of caseinolysis at $70 \mathrm{kD}$ ) and immunochemical inhibition (fig. 1.4), these were all of tPA type; no detectable uPA activity was observed.

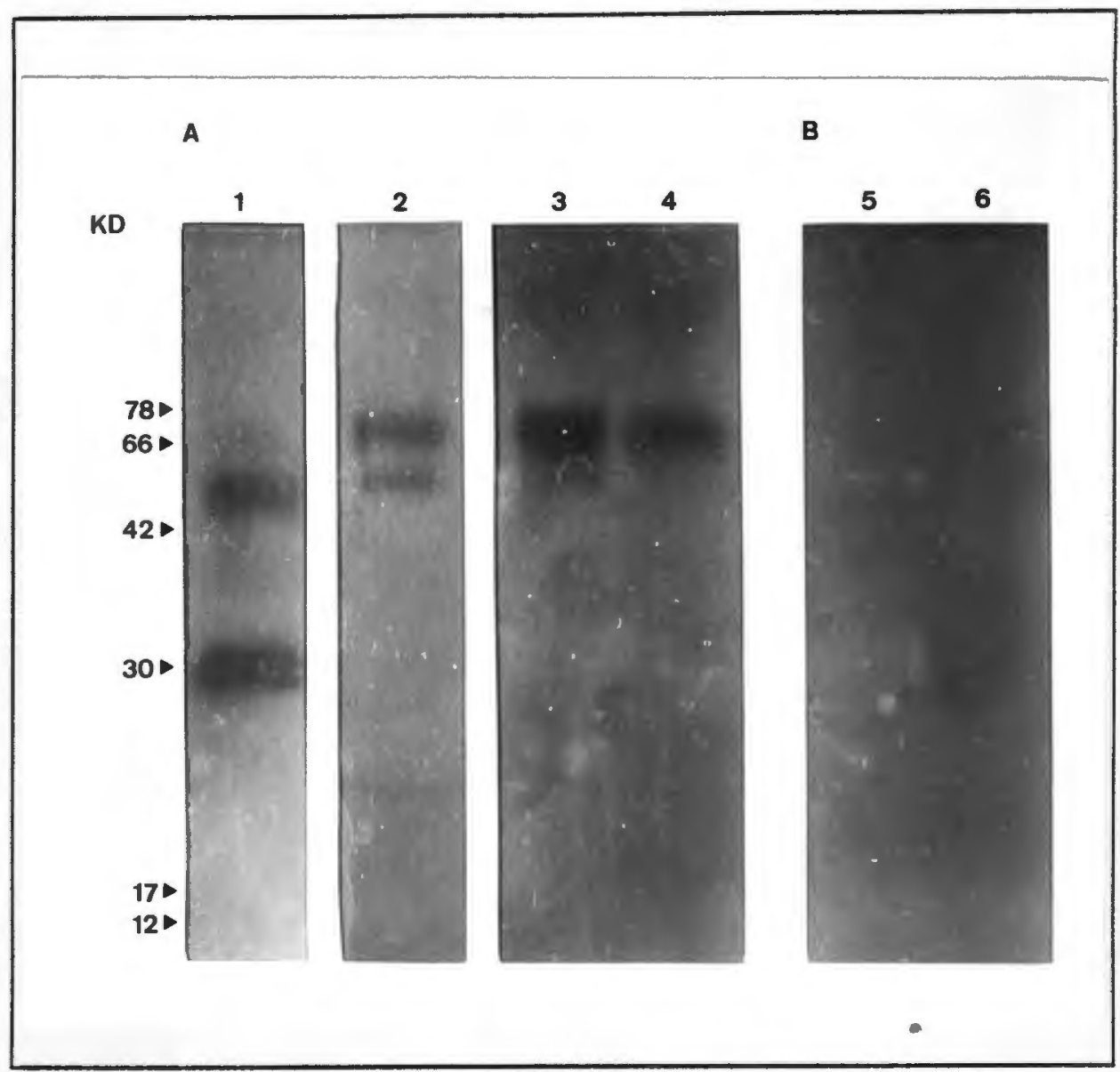

Figure 1.4

SDS PAGE and zymography of UCT-Mel 3 cell lysate and conditioned medium. Conditioned medium ( $20 \mu$ collected from $10^{6} \mathrm{cells} / 60 \mathrm{~mm}$ dish) and cell lysate $\left(20 \mu \mathrm{l}\right.$ of $\left.10^{6} \mathrm{cells} / \mathrm{ml}\right)$ were electrophoresed on a $12 \%$ polyacrylamide gel. The gel was washed in $2.5 \%$ Triton- $X 100$ for one hr and the resolved enzyme bands were detected by incubation on an indicator agar layer containing casein and plasminogen. Lane 1, uPA standard $(1.25 \mathrm{mU} / \mathrm{ml})$, lane 2, tPA standard (20 $\mu \mathrm{l}$ Bowes conditioned medium), lanes 3 and 5, UCT-Mel 3 conditioned medium, lanes 4 and 6, UCT-Mel 3 cell lysate. Panel A: standard overlay. Panel B: overlay incorporating $\alpha$-tPA antibody 
Electrophoresis and northern blotting of mRNA isolated from UCT-Mel 3 cells showed the definite, albeit faint, presence of tPA message. Despite prolonged autoradiography of the blots no uPA message was observed. The RNA isolated from HT1080 cells showed prominent bands that hybridized with probes for IPA (2700 bases) and UPA (2500 bases). These results are presented in fig. 1.5. UCT-Mel 3 cells thus transcribed and translated active tPA. No uPA mRNA or enzyme activity was detected using the above methods.

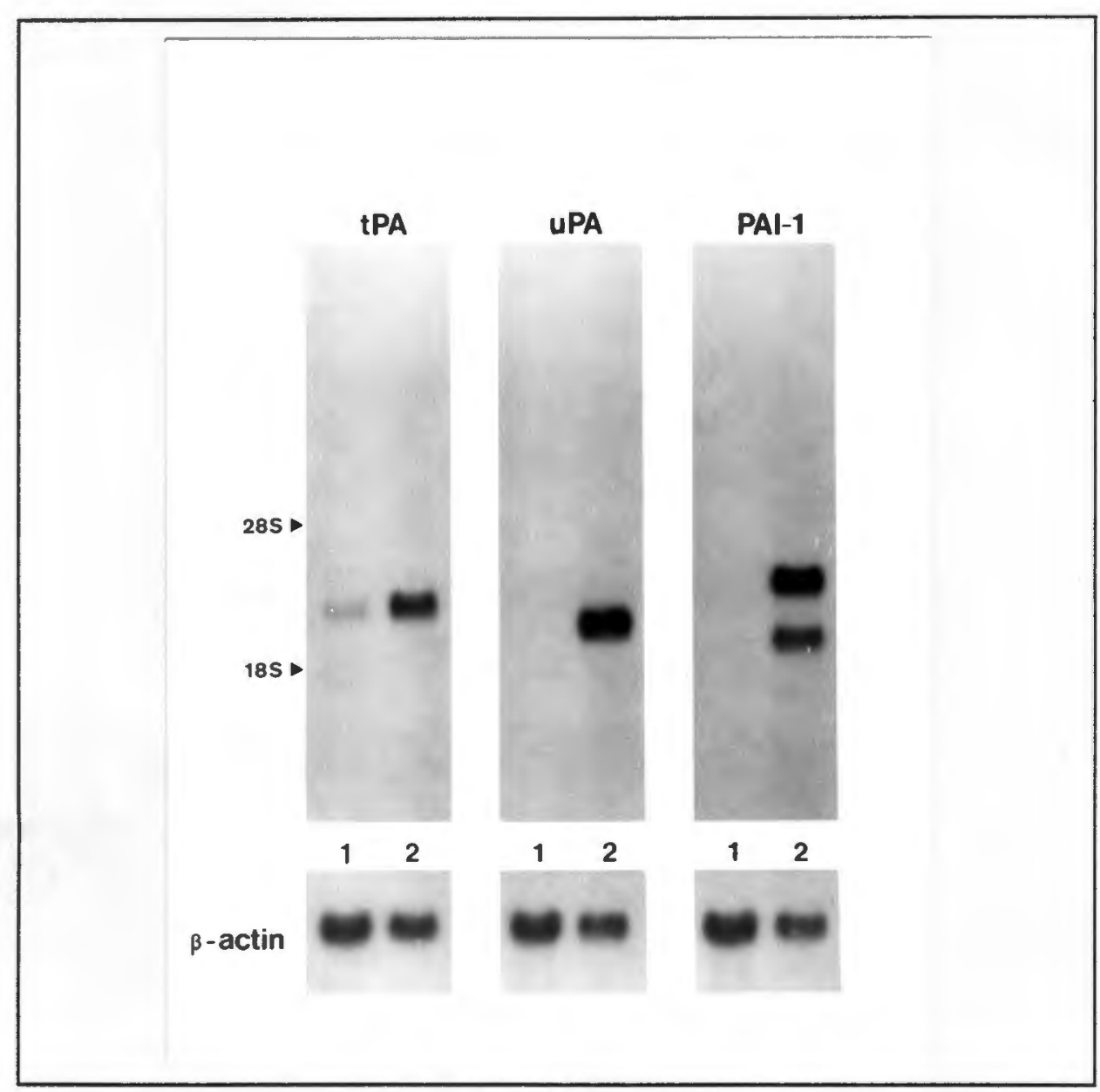

Figure 1.5

Northern Blot analysis of IPA, UPA and PAl-1 gene expression in UCT-Mel 3 and HT1080 cells

Total RNA was isolated from UCT-Mel 3 (lane 1) and HT1080 cells (lane 2) and 20 $\mu \mathrm{g} / \mathrm{lane}$ was electrophoresed on a $1 \%$ agarose-formaldehyde gel. The gel was blotted as described, and hybridized with 32 P-labelled CDNA probes for IPA, UPA and PAl-1. Blots were washed and autoradiographed for 7 days. The blots were then stripped and rehybridized with a probe for $\beta$-actin (lower panels). 
Analysis of cells isolated from metastatic deposits in the adrenal and lung similarly showed only tPA activity and TPA mRNA (fig. 1.6). No evidence of UPA transcription or synthesis was found. However I am unable to exclude the existence of unstable uPA transcripts. It is of interest to note that the signal for tPA message in the northern blots of the metastatic cells was more intense than that of the parent cell line.

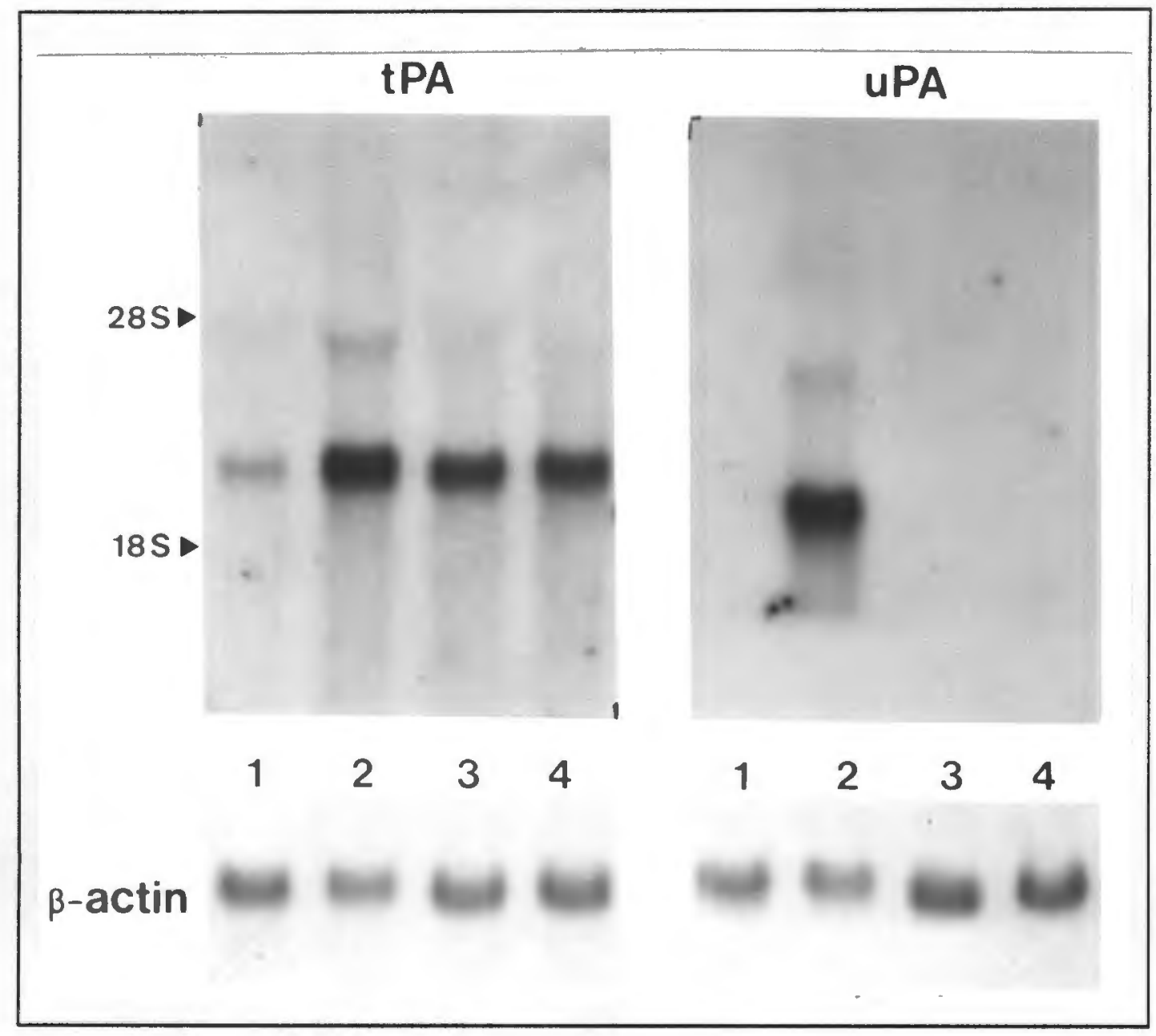

Figure 1.6

Northern Blot analysis of tPA and UPA gene expression in UCT-Mel 3 adrenal and lung metastatic deposits

Total RNA was isolated from cultured adrenal (lane 3) and lung (lane 4) metastatic deposits after the fourth passage. $20 \mu \mathrm{g} /$ lane was electrophoresed, together with parental UCT-Mel 3 (lane 1) RNA for comparison and HT1080 RNA (lane 2) as positive control, on a 1\% agaroseformaldehyde gel. The gel was treated and blotted as described and hybridized with 32P. labelled cDNA probes for IPA and uPA. The blots were washed and autoradiographed for 10 days and then stripped and rehybridized with a $\beta$-actin probe (lower panels). 
This did not correspond with the level of tPA released by the two cell cultures, as measured in the fibrin plate activity assay. Parental cells and metastatic cells released similar amounts of PA activity when corrected for a cell density of $5 \times 10^{5}$ cells $/ 60 \mathrm{~mm}$ dish (tabie 1.2). The amount of PA/cell released by UCT-Mel 3 decreased with increasing cell density. In order to obtain a linear relationship, results were converted to PA units $/ 10^{6}$ cells $/ 24 \mathrm{hr}$, and plotted against cell number on log scales.

Table 1.2 Levels of PA release by UCT-Mel 3 parent and metastatic cells.

\begin{tabular}{|l|c|c|c|c|}
\hline \multirow{2}{*}{ CELL TYPE } & PA (1) & \multicolumn{3}{|c|}{ REGRESSION PARAMETERS (2) } \\
\hline & & M & C & $r$ \\
\hline PARENT & 2.359 & $-0.464 \pm 0.116$ & $3.013 \pm 0.673$ & 0.917 \\
AM & 2.104 & $-0.372 \pm 0.049$ & $2.443 \pm 0.276$ & 0.967 \\
LM & 2.827 & $-0.662 \pm 0.038$ & $4.224 \pm 0.220$ & 0.993 \\
\hline
\end{tabular}

(1) PA release calculated from regression for a cell density of $5 \times 10^{5}$ cells $/ 60 \mathrm{~mm}$ dish

(2) Regression parameters given for the equation:

$\log (y)=m \cdot \log (x)+c$

$y=P A$ release $/ 10^{6}$ cells $/ 24 \mathrm{hr}$

$\mathrm{X}=$ cells $/ 60 \mathrm{~mm}$ dish

$r=$ correlation coefficient

\section{PAI-1 synthesis by UCT-Mel 3 cells}

Neither ELISA analysis for PAI-1 protein nor northern blot analysis for PAI-1 mRNA (fig. 1.5) provided evidence for the synthesis of this inhibitor by UCT-Mel 3 parent cells. Simultaneous analysis of HT1080 cell mRNA showed prominent bands (approximately 2300 bases and 3200 bases) that hybridized with the PAl-1 probe (fig. 1.5). It was of interest to note that the metastatic cells isolated from the adrenal deposit contained a small amount of PAI-1 message whose presence could be demonstrated in two separate northern blot experiments, the result from 
one of these is shown in fig. 1.7. This correlated with the detectable release of PAI- 1 by the culture of adrenal metastatic UCT-Mel 3 cells (table 1.3), as measured by PAI-1 ELISA. Cells cultured from the lung metastatic deposit also secreted detectable levels of PAI-1 protein, although the level was lower.

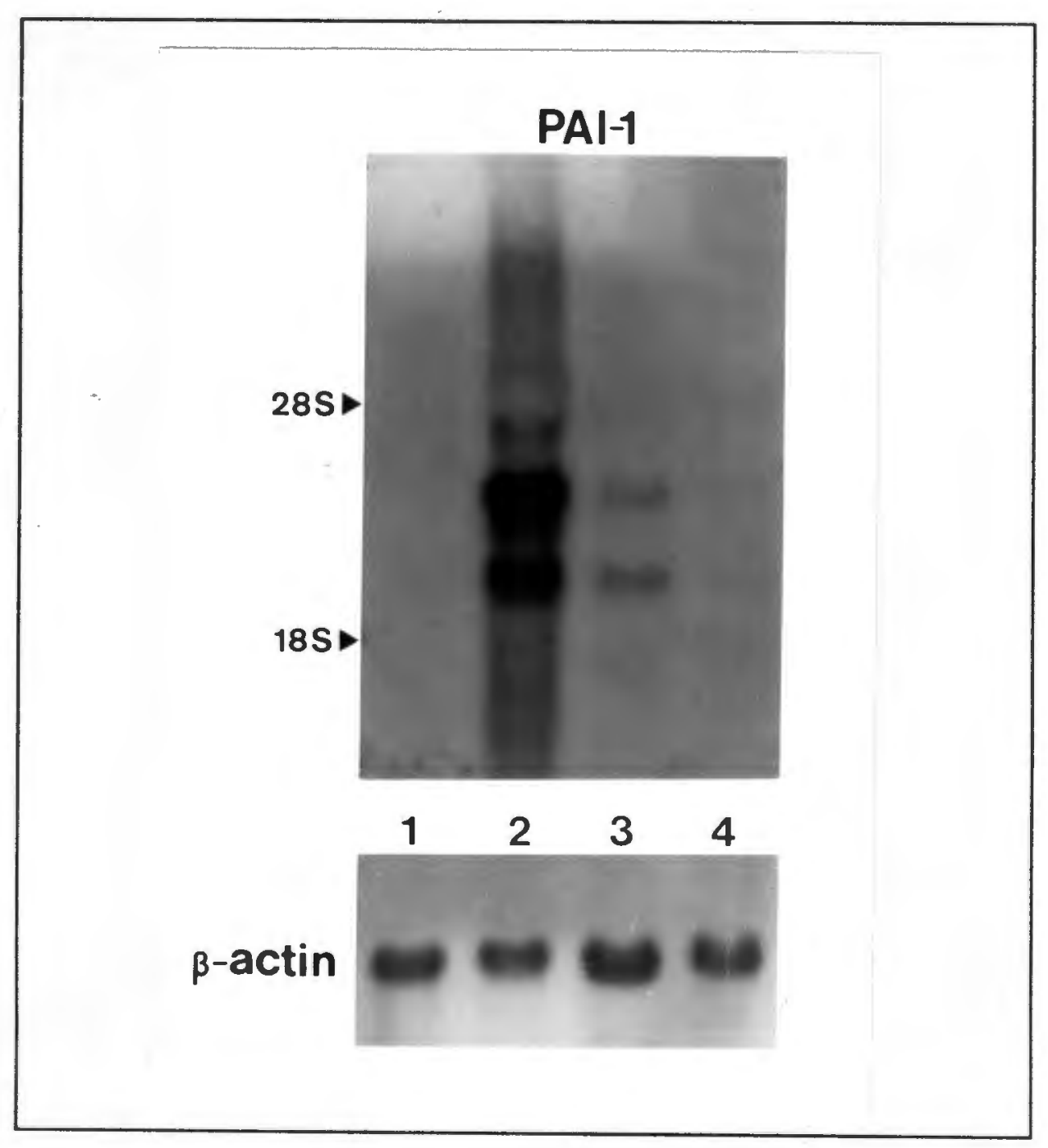

Figure 1.7

Northern blot analysis of PAl-1 gene expression in UCT-Mel 3 adrenal and lung metastatic deposits

Total RNA isolated from cultured adrenal (lane 3) and lung (lane 4) metastatic deposits after the fourth passage. The RNA was electrophoresed ( $20 \mu \mathrm{g} /$ lane) together with that of UCT-Mel 3 parental (lane 1) and HT1080 (lane 2) on a $1 \%$ agarose-formaldehyde gel. The gel was treated and blotted as described and then hybridized with a ${ }^{32}$ P-tabelled PAI-1 CDNA probe. The blot was washed, autoradiographed for 14 days and then stripped and rehybridized with a $\beta$-actin probe. The results shown are representative of two separate experiments. 
Table 1.3 PAI-1 levels in concentrated (10-fold) conditioned media from UCT-Mel 3, adrenal and lung metastatic cells, as measured by ELISA.

\begin{tabular}{|l|l|}
\hline cell type & PAI-1 (ng/ml) \\
\hline parental UCT-Mel 3 & $\phi(1)$ \\
adrenal met. & 3.31 \\
lung met. & 0.56 \\
\hline
\end{tabular}

(1) not detectable

\section{Synthesis of UPA receptor by UCT-Mel 3 cells}

Northern blot analysis of RNA isolated from UCT-Mel 3 cells showed the weak (relative to HT1080) but none the less definite and consistent presence of a band that hybridized with the UPAR probe (fig. 1.8). Interestingly the adrenal metastatic cells express higher levels of mRNA for UPAR than do the parent UCT-Mel 3 cells or the lung metastatic cells (fig. 1.9).

Binding studies, using radio labelled ATF as ligand and U937 cells as a positive control (64), were therefore undertaken to identify functional uPA receptor on UCT-Mel 3 cells. Initially, specific binding of 125|-ATF was demonstrated by competing out binding of labelled ATF with increasing concentrations of unlabeled ATF (fig. 1.10).

For Scatchard analysis, increasing amounts of labelled ATF were added in the presence of an excess of unlabeled ATF (data shown in tables 1.4 and 1.5). Both U937 cells and UCT-Mel 3 cells showed saturable binding of ATF (fig. 1.11). 


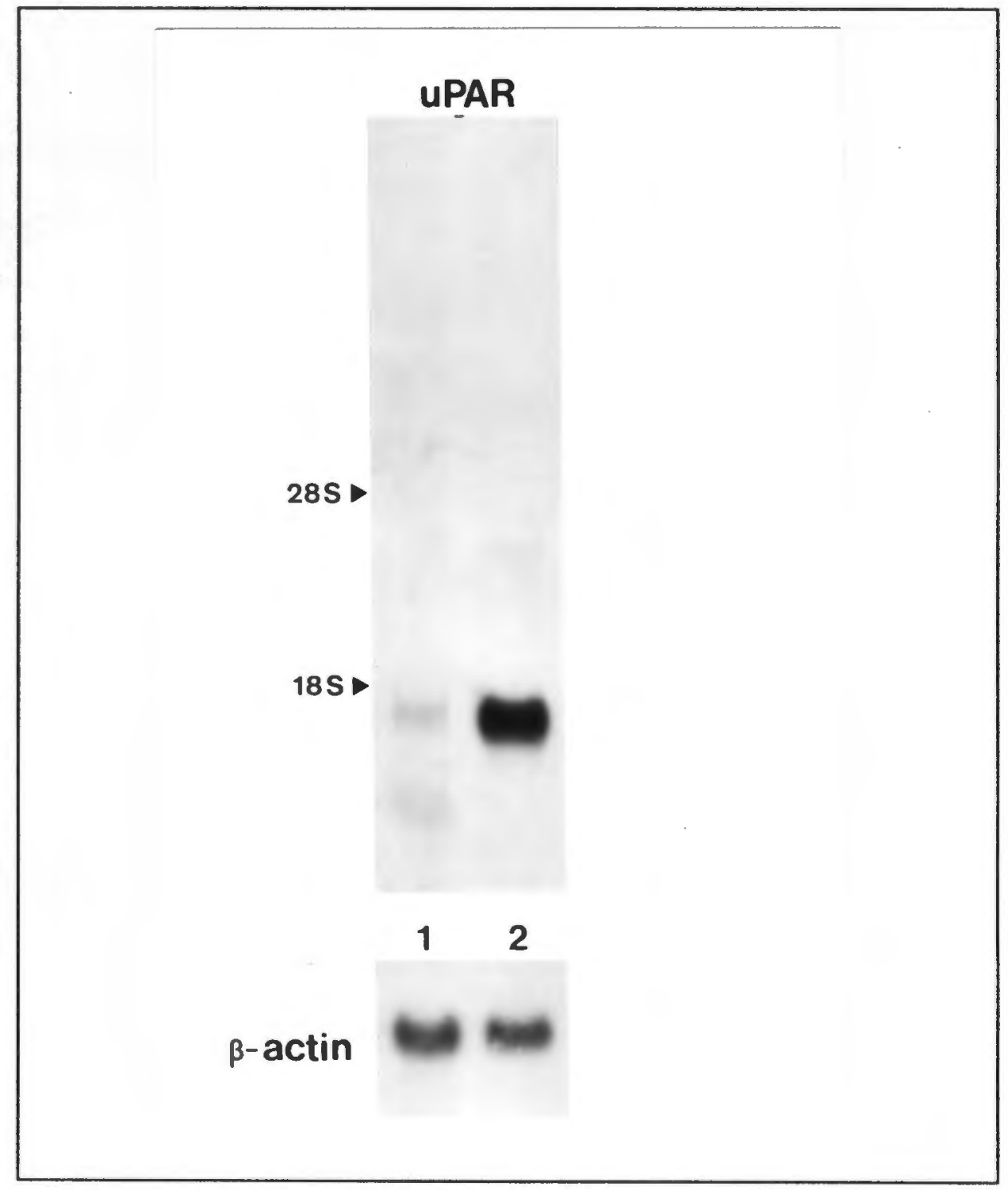

Figure 1.8

Northern blot analysis of UPAR gene expression in UCT-Mel 3 and HT1080 cells

Total RNA isolated from UCT-Mel 3 (lane 1) and HT1080 (lane 2) cells was electrophoresed on a $1 \%$ agarose-formaldehyde gel ( $20 \mu \mathrm{g} / \mathrm{lane})$. The gel was treated and blotted as described and then hybridized with a ${ }^{32}$ P - labelled cDNA probe for UPAR. The blot was washed, autoradiographed for 10 days and then stripped and rehybridized with a $\beta$-actin probe (lower panels). 


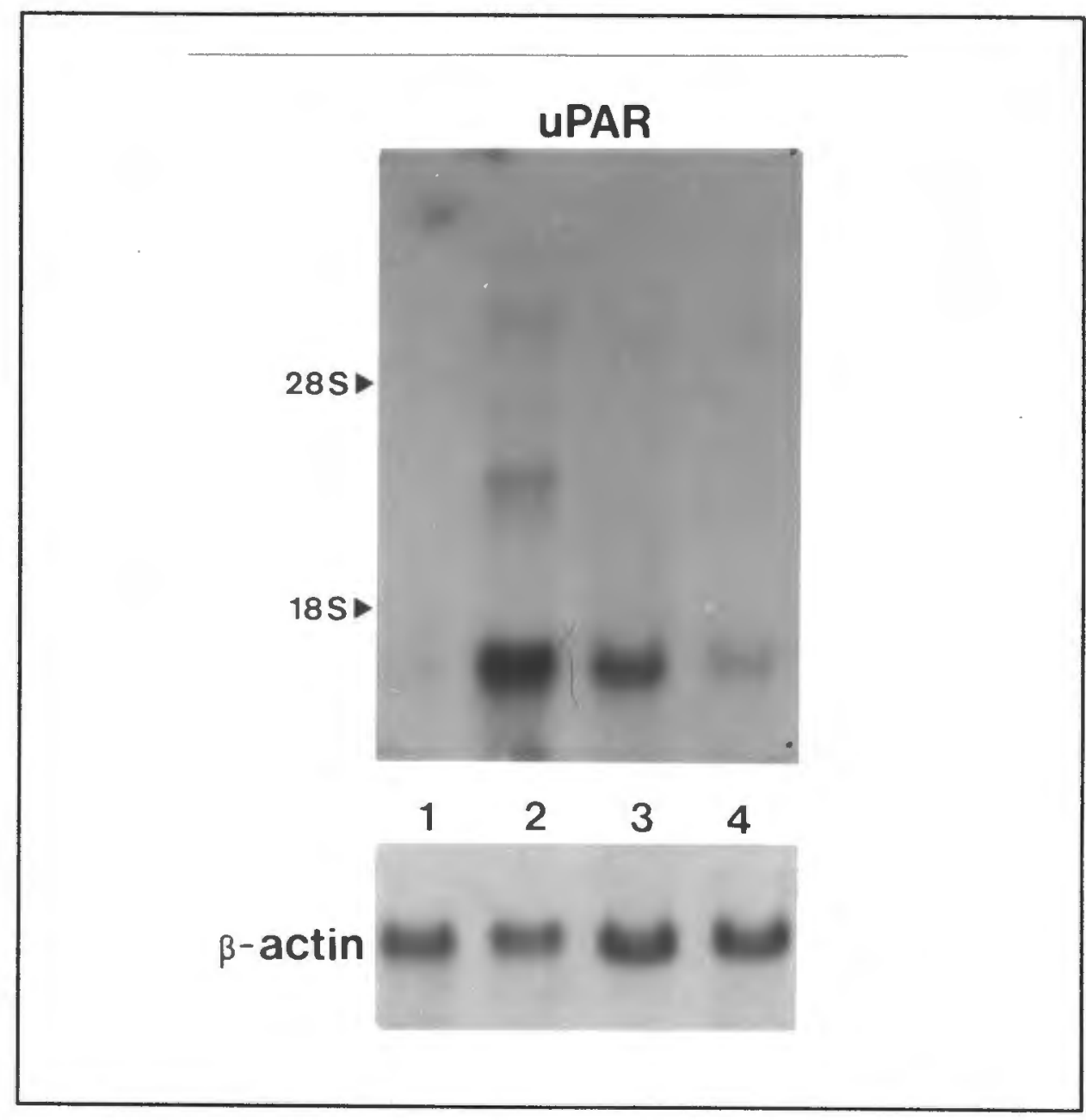

Figure 1.9

Northern blot analysis of UPAR gene expression in UCT-Mel 3 adrenal and lung metastatic deposits

Total RNA was isolated from cultured UCT-Mel 3 adrenal (lane 3) and lung (lane 4) metastatic deposits after the fourth passage. $20 \mu \mathrm{g}$ of total RNA was electrophoresed together with RNA from parental (lane 1) and HT1080 cells (lane 2) on a $1 \%$ agarose-formaldehyde gel. The gel was treated and blotted onto Hybond-N as described and then hybridized with a ${ }^{32}$-labelled UPAR CDNA probe. The blot was washed, autoradiographed for 10 days and then stripped and rehybridized with a $\beta$-actin probe (lower panels). 
A

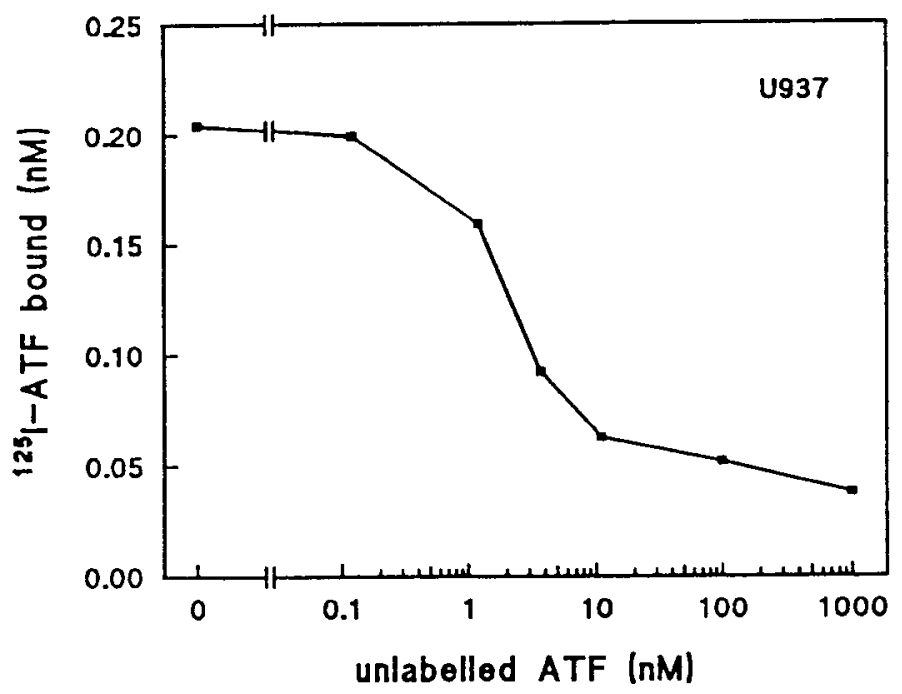

B

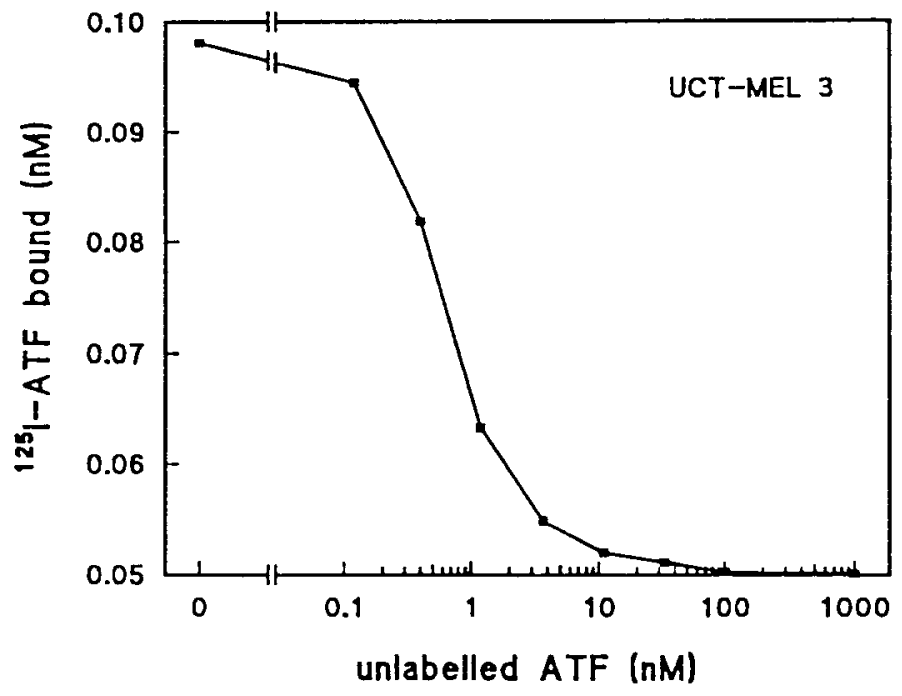

Figure 1.10

Binding of ${ }^{125}$-labelled ATF to U937 and UCT-Mel 3 cells in the presence of increasing concentrations of unlabelled ATF

A fixed concentration of functionally active ${ }^{125}$-labelled ATF $(0.25 \mathrm{nM})$ was incubated with $10^{6}$ U937 (A) or UCT-Mel 3 cells (B) in the presence of increasing concentrations of unlabelled ATF. Incubations were performed in a volume of 200 $\mu \mathrm{l}$ at $4^{\circ} \mathrm{C}$ for $2 \mathrm{hr}$. The concentration of labelled ATF bound is plotted as a function of the concentration of unlabelled ATF added. 
Table 1.4 Scatchard analysis of data from binding of 125 I-ATF to U937 cells

\begin{tabular}{|c|c|c|c|c|}
\hline $\begin{array}{l}\text { ATF }(n M) \\
\text { added }\end{array}$ & $\begin{array}{l}\text { bound }(2) \\
(\mathrm{cpm})\end{array}$ & $\begin{array}{l}\text { bound } \\
(\mathrm{nM})\end{array}$ & $\begin{array}{l}\text { free }(4) \\
(\mathrm{nM})\end{array}$ & $b / f$ \\
\hline 10.000 & 14771 & 0.394 & 9.606 & 0.398 \\
\hline 5.000 & 13044 & 0.348 & 4.652 & 0.726 \\
\hline 2.500 & 12775 & 0.341 & 2.159 & 1.522 \\
\hline 1.250 & 9802 & 0.262 & 0.988 & 2.554 \\
\hline 0.625 & 6534 & 0.175 & 0.450 & 3.544 \\
\hline 0.313 & 3474 & 0.093 & 0.220 & 3.843 \\
\hline${ }^{\star} 0.156$ & 1731 & 0.046 & 0.110 & 3.857 \\
\hline${ }^{\star} 0.078$ & 965 & 0.026 & 0.052 & 4.401 \\
\hline${ }^{\star} 0.039$ & 515 & 0.014 & 0.025 & 4.762 \\
\hline${ }^{\star} 0.020$ & 223 & 0.006 & 0.014 & 3.951 \\
\hline${ }^{*} 0.010$ & 191 & 0.005 & 0.005 & 9.259 \\
\hline${ }^{\star} 0.005$ & 93 & 0.003 & 0.002 & 8.701 \\
\hline
\end{tabular}

Table 1.5 Scatchard analysis of data from binding of ${ }^{125 I}$-ATF to UCT-Mel 3 cells

\begin{tabular}{|c|c|c|c|c|}
\hline $\begin{array}{l}\text { ATF }(\eta M) \\
\text { added }(I)\end{array}$ & $\begin{array}{l}\text { bound }(2) \\
\text { (cpm) }\end{array}$ & $\begin{array}{l}\text { bound (3) } \\
\text { (nM) }\end{array}$ & $\begin{array}{l}\text { free }(4) \\
(n M)\end{array}$ & $b / f$ \\
\hline${ }_{10.000}$ & 16234 & 0.434 & 9.566 & 0.044 \\
\hline 5.000 & 5064 & 0.135 & 4.865 & 0.027 \\
\hline 2.500 & 5598 & 0.150 & 2.350 & 0.061 \\
\hline 1.250 & 5342 & 0.143 & 1.107 & 0.124 \\
\hline 0.625 & 3845 & 0.103 & 0.522 & 0.182 \\
\hline 0.313 & 2449 & 0.065 & 0.248 & 0.243 \\
\hline 0.156 & 1189 & 0.032 & 0.124 & 0.237 \\
\hline 0.078 & 644 & 0.017 & 0.061 & 0.256 \\
\hline 0.039 & 376 & 0.010 & 0.029 & 0.309 \\
\hline${ }^{\star} 0.019$ & 203 & 0.005 & 0.014 & 0.348 \\
\hline${ }^{*} 0.010$ & 128 & 0.003 & 0.007 & 0.479 \\
\hline${ }^{\star} 0.005$ & 77 & 0.002 & 0.003 & 0.625 \\
\hline
\end{tabular}

(1) concentration of functionally active ${ }^{125}$-ATF added

(2) $\mathrm{cpm}$ bound after subtracting non-specific control cpm (12\% of cpm added) bound in the presence of $1 \mu \mathrm{M}$ unlabeled ATF

(3) bound cpm converted to bound $\mathrm{nM}$

(4) concentration of free ATF, obtained by subtracting ${ }^{(2)}$ from ${ }^{(1)}$

data obtained at low ligand concentrations were not included for scatchard analysis 
A

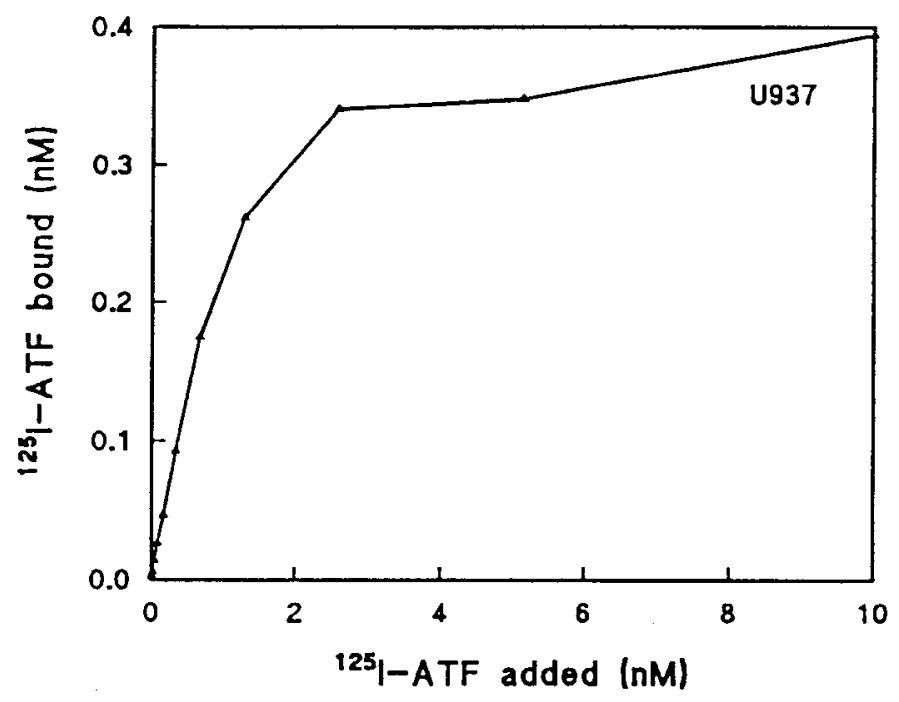

B

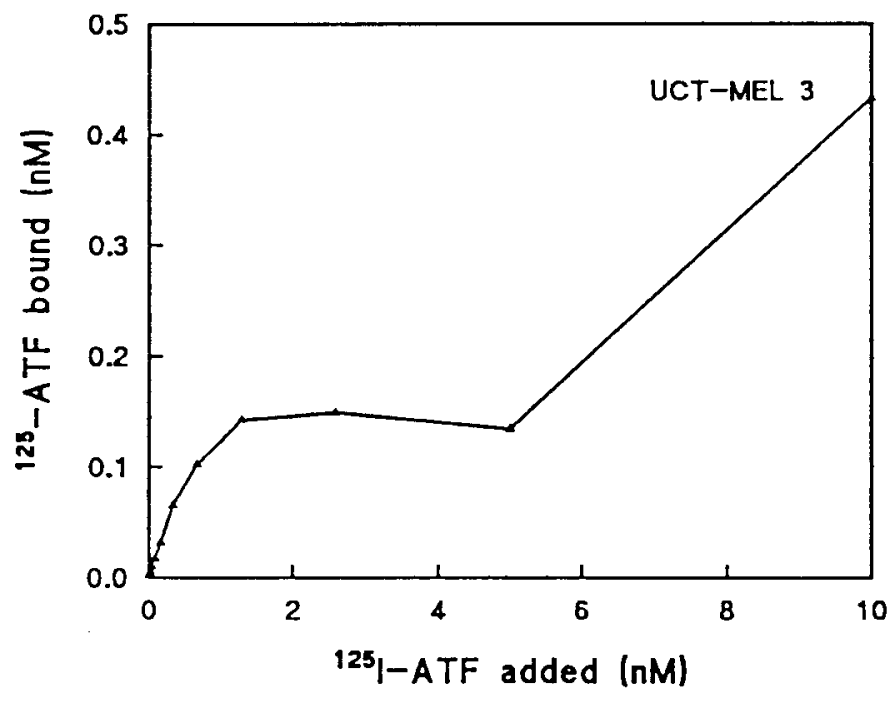

Figure 1.11

Binding of labelled ATF to U937 and UCT-Mel 3 cells Increasing amounts of labelled ATF were added to $10^{6}$ cells and incubated on ice for $2 \mathrm{hr}$. Cells were then spun through a layer of FCS and the cell bound radioactivity in the pellet counted. Non-specific binding was determined in the presence of an excess of unlabelled ATF and subtracted from the total counts. 


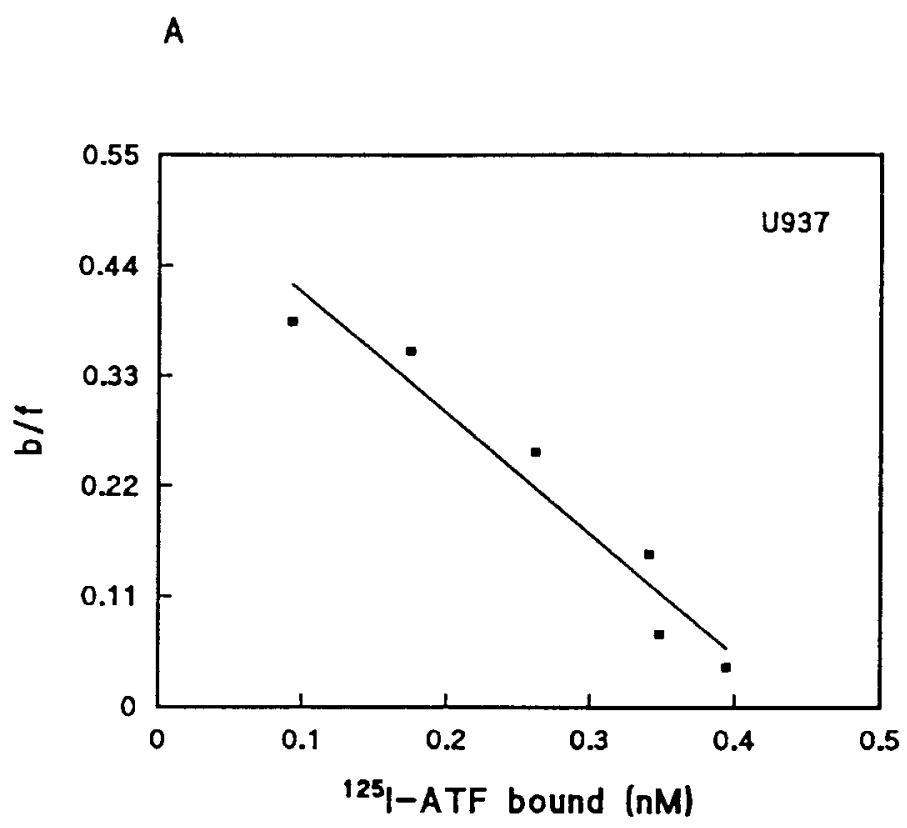

B

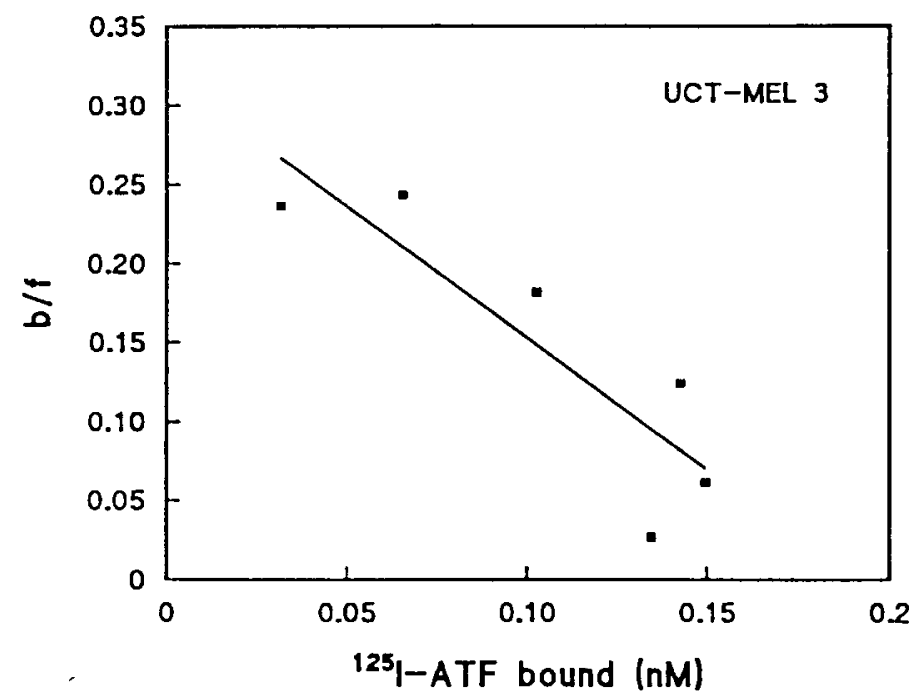

Figure 1.12

Scatchard analysis of ${ }^{125}$-labelled ATF binding to U937 and UCT-Mel 3 cells (data from table 1.4 and 1.5)

Increasing concentrations of 125 -labelled ATF were incubated with $10^{6}$ U937 or UCT-Mel 3 cells at $4^{\circ} \mathrm{C}$ for $2 \mathrm{hr}$. Duplicate tubes containing an excess of unlabelled ATF $(1 \mu \mathrm{M})$ were included for calculation of non-specific binding. The $K_{d}$ (inverse of the slope) was calculated to be $0.83 \mathrm{nM}$ for U937 cells and 0.59 $\mathrm{nM}$ for UCT-Mel 3 cells. The X-axis intercept representing the number of sites is $0.442 \mathrm{nM}$ (53 200 sites/cell) for U937 cells and $0.19 \mathrm{nM}$ (22 800 sites/cell) for UCT-Mel 3 cells. 
Scatchard analysis of U937 binding showed the presence of a single receptor with a dissociation constant of $0.83 \mathrm{nM}$ and present at a density of $5 \times 10^{4}$ binding sites per cell (fig. 1.12A). UCT Mel 3 cells appeared to express a similar receptor with a $K_{d}$ of $0.59 \mathrm{nM}$ present at a density of $20 \times 10^{3} /$ cell (fig. 1.12B). However at ligand concentrations greater than $5 \mathrm{nM}$, there appeared to be a sharp increase in binding to UCT-Mel 3 cells (table $1.5^{*}$ ). Although there was insufficient data for scatchard analysis of this putative second class of receptor, it appeared to be of low affinity and high density. 
Southern blot analysis of UCT-Mel 3 cell DNA for the presence of UPA, PAI1, UPAR and TPA genes

Digests of UCT-Mel 3 DNA were electrophoresed, blotted and probed for the presence of tPA, UPA, PAI-1 and UPAR genes to give the results shown in figs. 1.13 and 1.14. As is evident for this blot, the UCT-Mel 3 DNA digests contain a pattern of bands for the 4 genes that were similar, in size to the corresponding digest of HT1080 DNA. One exception was the additional band in the UCT-Mel 3 lane which hybridized to the tPA probe (fig. 1.13).

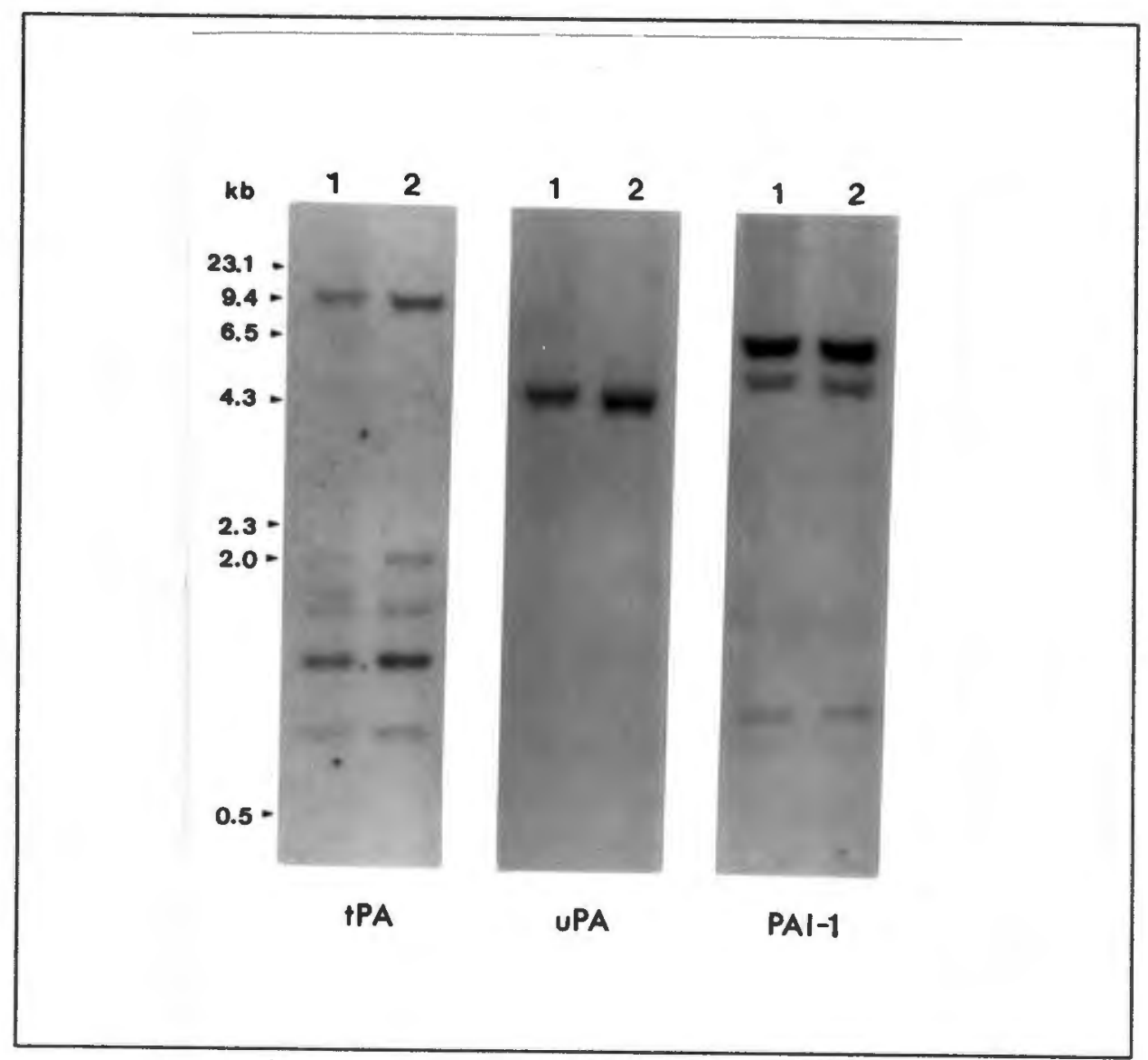

Figure 1.13

Southern blot analysis of tPA, UPA and PAI-1 genes in UCT-Mel 3 and HT1080 DNA

$10 \mu \mathrm{g}$ of Hindlil and EcoRI digested UCT-Mel 3 (lane 1) and HT1080 (lane 2) DNA was electrophoresed on a $0.7 \%$ agarose gel and blotted onto Hybond $N$ (as described). The blot was hybridized to ${ }^{32} \mathrm{P}$-labelled CDNA probes for IPA, UPA and PAl-1, washed and autoradiographed for 10 days. The mobilities of $\lambda /$ HindIII molecular weight markers are indicated. 


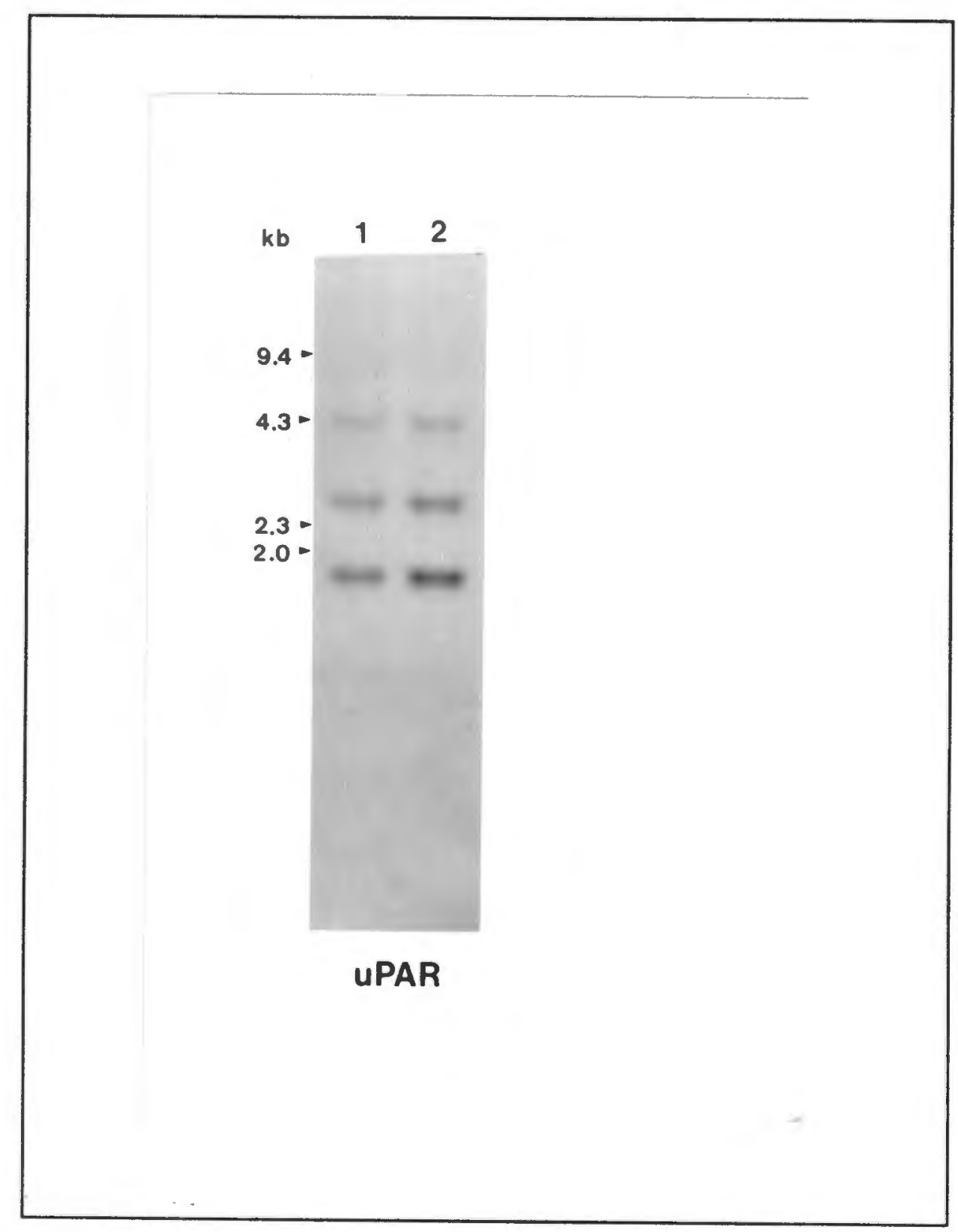

Figure 1.14

Southern blot analysis of the uPAR gene in UCT-Mel 3 and HT1080 DNA $10 \mu \mathrm{g}$ of HindIII and EcoRI digested UCT-Mel 3 (lane 1) and HT1080 DNA was electrophoresed on a $0.7 \%$ agarose gel and blotted onto Hybond $N$ (as described). The blot was hybridized to a 32 p-labelled cDNA probe for UPAR, washed and autoradiographed for 10 days. The mobilities of $\lambda /$ HindllI molecular weight markers are indicated. 
The band sizes obtained for UPA (single band $>2.7 \mathrm{~kb}$ ) and PAl-1 $(6.9,4.8$ and $0.9 \mathrm{~kb})$ corresponded to those expected from the published gene sequences. The sequence of the UPAR gene was unfortunately not available to me. For the tPA gene, the expected bands of 10 and $2 \mathrm{~kb}$ were obtained. However the remaining bands obtained $(1.5,1.2,1.0$ and $0.8 \mathrm{~kb})$ did not correspond with the expected bands of $1.5,1.4$, and $>0.5 \mathrm{~kb}$. [" $>$ " is used to indicate $5^{\prime}$ or $3^{\prime}$ end fragments which may also contain bordering sequences]. 


\section{Discussion}

The results I report in this chapter warrant comment in a number of respects.

Firstly, I have shown that cells from a highly metastatic cell line both failed to synthesize UPA and to transcribe detectable steady state levels of UPA mRNA. Since the gene for UPA was present in the cells, it is admittedly possible that they are induced to synthesize uPA when they took the form of a solid tumour in vivo and this capacity is lost when they are dispersed as an in vitro culture. I did not examine the freshly excised tumours of metastases, by immunohistochemistry or by preparing tumour lysates to see if this was the case so I am unable to discount this possibility entirely. If this did not occur one may conclude that invasion and metastasis is possible without the presence of human derived uPA.

Since UCT-Mel 3 cells displayed UPA receptor one might argue that the UPA required for metastasis to occur could have been provided by the environmental host cells. This, however, is unlikely to occur in the nude mouse since human UPAR do not bind murine UPA $(44,57)$. Unlike U937 cells, UCT-Mel 3 cells appeared to express two classes of receptors - one with relatively high affinity, that was similar to the receptor found on other cell types and possibly a second, with low affinity, that was present in greater numbers. It is conceivable that murine uPA bound to the latter with an affinity sufficient to provide the proteolytic potential for spread.

I found the binding experiments with ${ }^{25 \mid}$-labelled ATF technically difficult to perform and interpret. It was evident that a large fraction of the labelled ATF, although physically intact, was functionally damaged and that the relative 
concentration of non-functional ligand increased with storage. Background counts were therefore high and I was uncertain of the extent to which radiolabelled, damaged ATF contributed to the non-specific binding values that I subtracted to derive data for the Scatchard plots. While I am confident that the data (figs. 1.10 and 1.11) show specific and saturable binding of ATF to both U937 and UCT-Mel 3 cells, I am less confident of the values obtained from the scatchard plots. The $K_{d}$ value which I obtained for the $U 937$ cells $(0.8 \mathrm{nM})$ differs from the $0.2 \mathrm{nM}$ described for these cells in the literature $(55,57)$. My results also yielded a higher number of receptors/cell $\left(50 \times 10^{3}\right)$ than the $10-20 \times 10^{3}$ previously quoted.

I found it interesting that PAI-1 was not detectable in the parent cell line yet I was able to demonstrate transcription in the adrenal metastasis and translation in both the adrenal and lung metastases. Two obvious explanations for this finding come to mind: first, PAl-1 synthesizing cells may be a very small fraction of the total in the parental line and thus undetectable. If, by chance, the metastatic clone were derived from one of these cells this would have had the effect of concentrating the local presence to the level of detection. Secondly, the environment provided by the adrenal gland and lung may have induced UCT-Mel 3 cells to express PAl- 1 by mechanisms that were not operational in the primary tumour.

The fact that PAl-1 was present in the metastases and not in the parental line none the less indicates that the presence of the inhibitor did not militate against spread. Studies on greater numbers of metastases are required to determine whether PAI- 1 expression is a consistent feature.

The results of the southern blots showed conclusively, that the lack of expression of UPA or PAI-1 (in the parental cells) was not due to gene deletion. Further than 
the mechanisms that were involved in repression of UPA or PAI- 1 in these cells remains to be elucidated. As I have indicated earlier, the lack of UPA transcription is a consistent feature of the melanoma phenotype and I think its study would be an interesting experimental investment. It has been shown that normal melanocytes secrete only IPA (102), although the cell culture method used involves addition of PMA, which may have altered the phenotype. It would, I believe, be reasonably straightforward to obtain answers to such questions as:

- Is it possible to induce expression in melanoma cells with one of the agents known to induce the enzyme in other cells?

- Would melanoma cells express UPA if transfected with the gene under the control of a different promoter?

- Is protein synthesis required to maintain repression of UPA synthesis?

- Are specific DNA binding proteins involved in the expression of UPA transcription?

- Do melanoma cells in vivo express uPA while they do not do so in vitro?

- Are regulatory sequences upstream from the UPA gene in melanoma cells consistently altered?

Unfortunately I had neither the time nor the facilities to divert into this interesting aspect of melanoma cell biology. It is unusual to find human malignant cells that do not express UPA, melanoma cells are an important and consistent example.

An interesting feature of the Southern blot for IPA was the presence of an additional band in the UCT-Mel 3 cell lane compared to the HT1080 lane. The possibility that this band may have arisen from partial digestion of the UCT-Mel 3 DNA cannot be excluded, although the HT1080 DNA was digested under the same conditions. Since both cell lines produced functional tPA, this anomaly may be due to a mutation, possibly within an intron, which does not affect enzyme function significantly. 


\section{PART 2}

Inhibition of tPA synthesis, clonal variation and presence tPA receptors in UCT-Mel 3 cells

\section{Introduction}

The results presented in part 1 showed, quite clearly, that a highly metastatic melanoma cell line neither released measurable UPA activity nor did it transcribe detectable uPA message (as detected by northern blot analysis). This finding led me to conclude that cell-derived urokinase activity is not an essential component of the metastatic phenotype.

The question then arose as to whether or not IPA activity could substitute for UPA in the metastatic context. The data reported by Quax et al. (91) suggested that UPA activity was essential and that IPA alone was insufficient. This view accords in principle with the general view $(123,124)$, that UPA is primarily involved in tissue remodelling, while the role of tPA is largely fibrinolytic.

To address this question, I felt that it would be useful, by genetic manipulation, to eliminate tPA synthesis in UCT-Mel 3 cells and to observe the effect upon the metastatic potential of tumours derived from the cells. Three approaches were available to me to achieve this:

- the stable transfection of antisense tPA gene fragments into the cells;

- the transfection of a specific anti-tPA mRNA ribozyme sequence into the cells;

- the transfection, into the cells, of a functional PAl-1 gene that would code for the synthesis of sufficient inhibitor to neutralize all tPA activity. 


\section{Antisense}

The use of antisense constructs to inactivate specific message has been widely and effectively applied in vitro (see 125, 126 for review). In experiments of this sort, single-stranded DNA oligonucleotides are added to the culture medium at concentrations high enough to ensure their intact passage into the cells where they bind message and effectively block translation. Such a strategy was obviously not appropriate for the long term in vivo studies I wished to undertake.

I therefore chose an approach in which I would transfect the cells with genetic constructs in which segments of DNA under a strong promoter would be constitutively transcribed to yield neutralizing antisense mRNA. Transfected clones would be selected for their lack of tPA secretion and these would be used to assay metastatic potential in the nude mouse.

For this purpose I chose a plasmid vector that I obtained from Dr. Pat Clissold (MIP unit, MRC, Cambridge). This contained a suitable cloning site into which the antisense gene could be cloned downstream of the potent CMV promoter, as well as a gene conferring Hygromycin resistance in mammalian cells. The plasmid had been transfected into human cells by Dr. Clissold to obtain stable expression (personal communication). The plasmid was supplied with the CAT gene in the cloning site; this could thus be used to ensure that the promoter was active in UCT-Mel 3.

\section{Ribozymes}

After the discovery (127) that RNA molecules could, when endowed with specific sequences and conformations, exert hydrolytic activity, it was to be expected that sequences encoding specific "designer" ribozymes would be transfected into eukaryotic cells with a view to destroying cognate message. 
A number of reports have attested to the useful validity of this approach (128130). Generally speaking, for an RNA molecule to have RNAse activity it should contain a defined sequence which forms a "hammerhead loop" that is flanked by two short sequences which are complementary to sequences flanking a target site which must contain a GTC triplet (fig. 2.4B). The ribozyme binds to the complementary sequences of the target mRNA and catalyses cleavage between the $T$ and $C$ of the target site (131).

All reports up to the time at which I performed the experiments dealt specifically with transient transfection of ribozyme oligonucleotides. In none of these had the authors attempted to achieve long term constitutive expression of a transfected DNA fragment that would encode a functional ribozyme. I saw no a priori reason why this should not be possible and I accordingly undertook a series of experiments that were designed to eliminate tPA synthesis by this method. One of the advantages offered by this approach was the fact that it was possible by in vitro transcription from a T7 or SP6 promoter to obtain ribozyme and confirm its enzyme activity using radio labelled target message.

\section{PAI-1}

As noted in chapter 1, parental UCT-Mel 3 cells do not synthesize detectable amounts of PAI-1 - a potent inhibitor of tPA activity. A way, therefore, of achieving inhibition of tPA activity would be to obtain stable transfectants of UCT-Mel 3 cells expressing PAI-1 in amounts sufficient to neutralize all cellular and extracellular tPA activity. This was a project undertaken by Mr. G.S. Hanekom, one of my colleagues in the laboratory. He successfully transfected cells with human PAI-1 under the control of the CMV promoter and was able, in short term experiments to achieve complete abrogation of all detectable tPA activity. 
Although seemingly straightforward, the antisense and ribozyme experiments did not give the results that I had hoped for. They did, however, raise a number of other issues that should provide interesting ground for further work.

As I shall report in this chapter the CMV promoter functioned effectively in UCTMel 3 cells when the CAT construct was transfected. I then went on to transfect the antisense construct in the confident hope that, by selecting with Hygromycin, I would be able to isolate clones with absent or diminished IPA activity. It transpired however, that effective Hygromycin selection was thwarted by the development of drug resistant clones whose ability to survive the antibiotic was unrelated to the presence of the resistance gene and was probably due to acquisition of a Hygromycin export mechanism similar to that which has been found in other chemoresistant malignant cells (132). The Hygromycin resistant clones that I subsequently selected for diminished tPA activity no longer contained the antisense construct. The low tPA activity appeared to be due to clonal variation within a highly heterogeneous and phenotypically unstable cell line.

In a final attempt to derive cells that could be used to study the relationship between tPA release and invasiveness, 1 isolated 20 clones from an untransfected culture. These I characterized with respect to 4PA release, growth rate and morphology. Unfortunately, I have not been able to assay their capacity for invasion or spread in the nude mouse. 


\section{Methods}

\section{"Sense" and "antisense" plasmids}

Two plasmids were used to prepare sense and antisense constructs for transfection; p17-CAT (a shuttle vector that was generously provided by Dr. Pat Clissold, MIP Unit, Cambridge) contained a $\beta$-lactamase gene (for selection in E. Coli); a gene conferring Hygromycin resistance (for selection in mammalian cells); the cytomegalovirus (CMV) promoter (for expression of cloned genes in mammalian cells); and the chloramphenicol acetyl transferase (CAT) gene under the control of the CMV promoter (fig. 2.1).

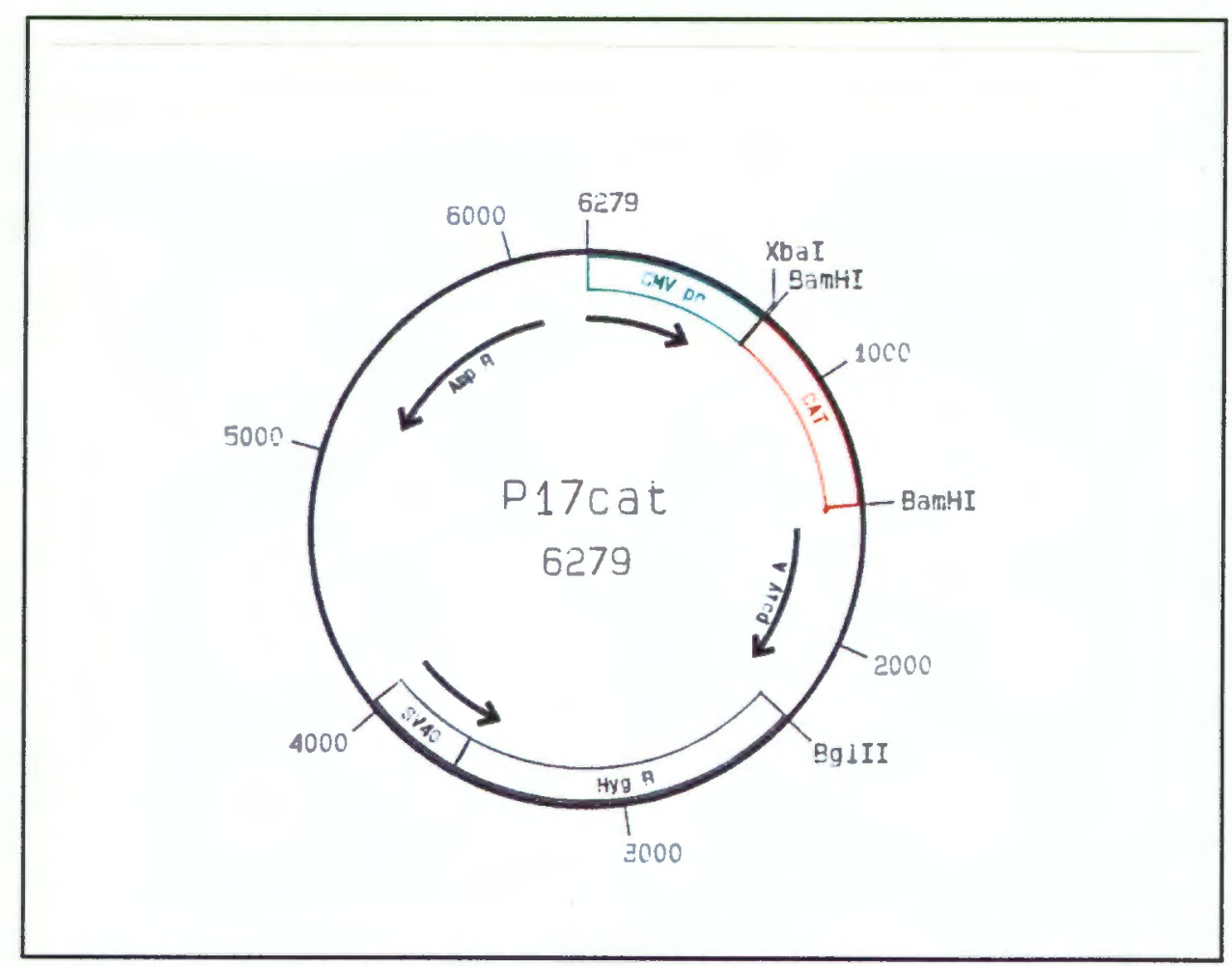

Figure 2.1

Diagrammatic representation of p17-CAT

P17-CAT contains the chloramphenicol acetyl transferase gene (CAT) under the control of the cytomegalovirus (CMV) promoter. The gene conferring Hygromycin resistance in mammalian cells is under the control of the SV40 promoter. 
pW349F (119) was kindly provided by Dr. S.J. Friezner-Degen. This plasmid contained a 2519 bp insert of human tPA cDNA cloned into the Pstl site of pBR322. Both plasmids were maintained in E. Coli DH5.

\section{A 1976 Bglll fragment containing the mature coding sequence for tPA was} excised from PW349F and ligated into p17, from which the CAT gene had been removed with BamHI (fig. 2.2). Bacteria (E. Coli, DH5) were transformed with the ligation product. Colonies picked from ampicillin containing plates and minipreps were prepared to establish the presence of the correct plasmid.

The orientation of the insert with respect to the CMV promoter was determined by digestion with Bglll and Smal. Single colonies containing sense (p17-tPAs) and

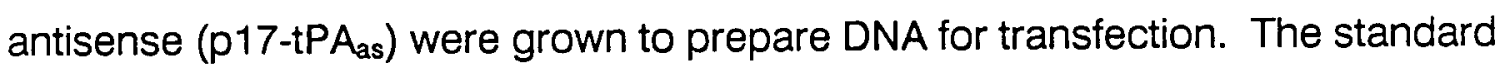
techniques used to prepare the plasmids are described in the appendix (A.22).

\section{Transfection and selection for Hygromycin resistance}

The UCT-Mel 3 cell line was titrated with various concentrations of Hygromycin B (Boehringer Mannheim) to determine the correct concentration that would be required to select transfected clones. Cells were seeded into $35 \mathrm{~mm}$ dishes at a density of $2 \times 10^{5} /$ dish in RP10 containing Hygromycin B at concentrations of 150 , $100,50,20,10,5$ and $2 \mu \mathrm{g} / \mathrm{ml}$. On days $0,2,4$ and 7 , cells were detached and trypan blue viability counts performed. Viable cell counts, obtained in the presence of varying Hygromycin concentrations, were plotted as a function of time (fig. 2.3). The appropriate concentration for selection was taken as the lowest concentration which inhibited growth completely, namely $50 \mu \mathrm{g} / \mathrm{ml}$. 

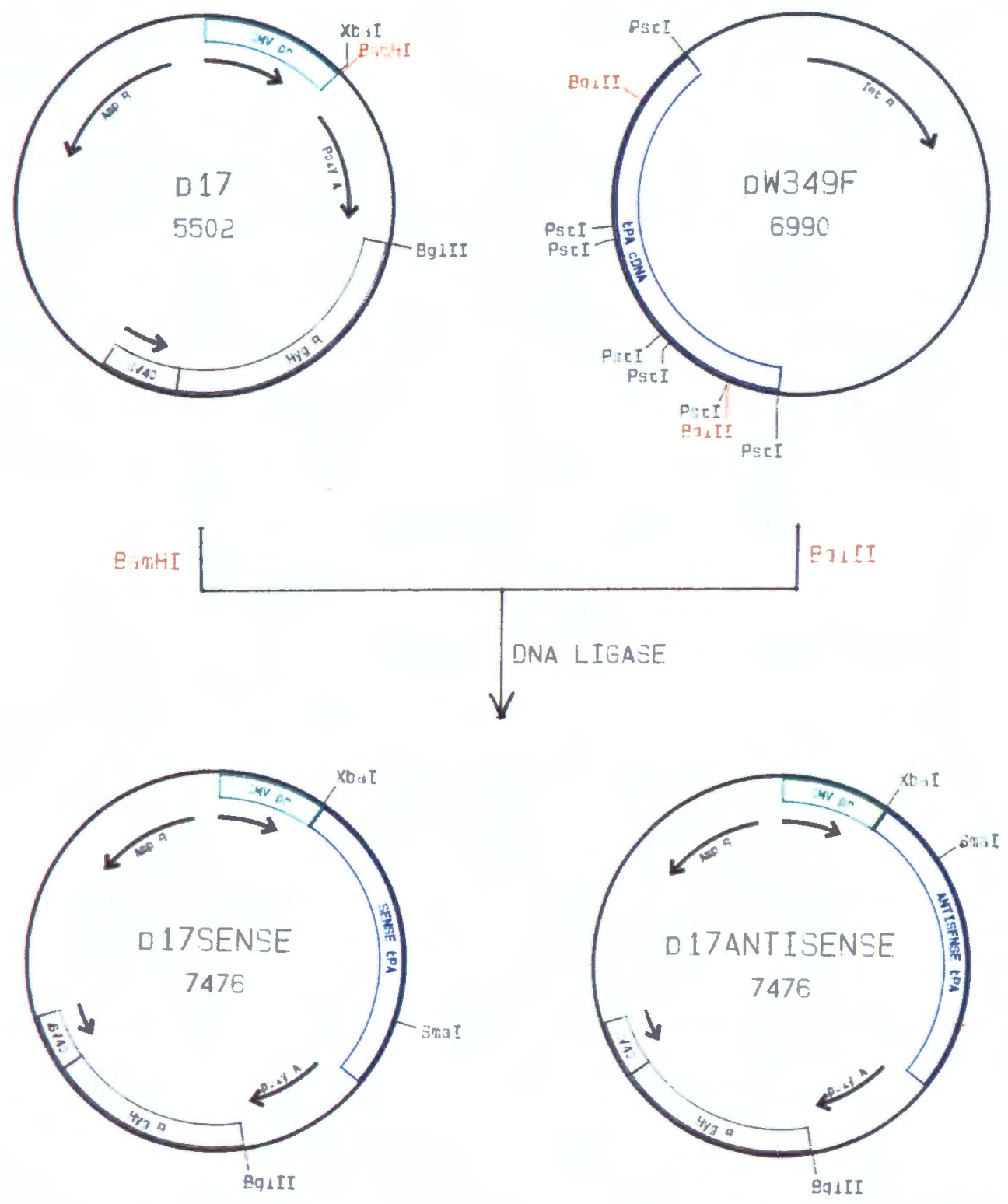

Figure 2.2

Construction of p17-tPA and p17-tPAas plasmids

pW349F was digested with Bglll, releasing a 2000 bp fragment of the tPA CDNA, this Bgill/tPA fragment was then ligated into the BamHI site of p17. The orientation of the IPA insert of recombinants was ascertained by digestion with Smal and Bglll. 


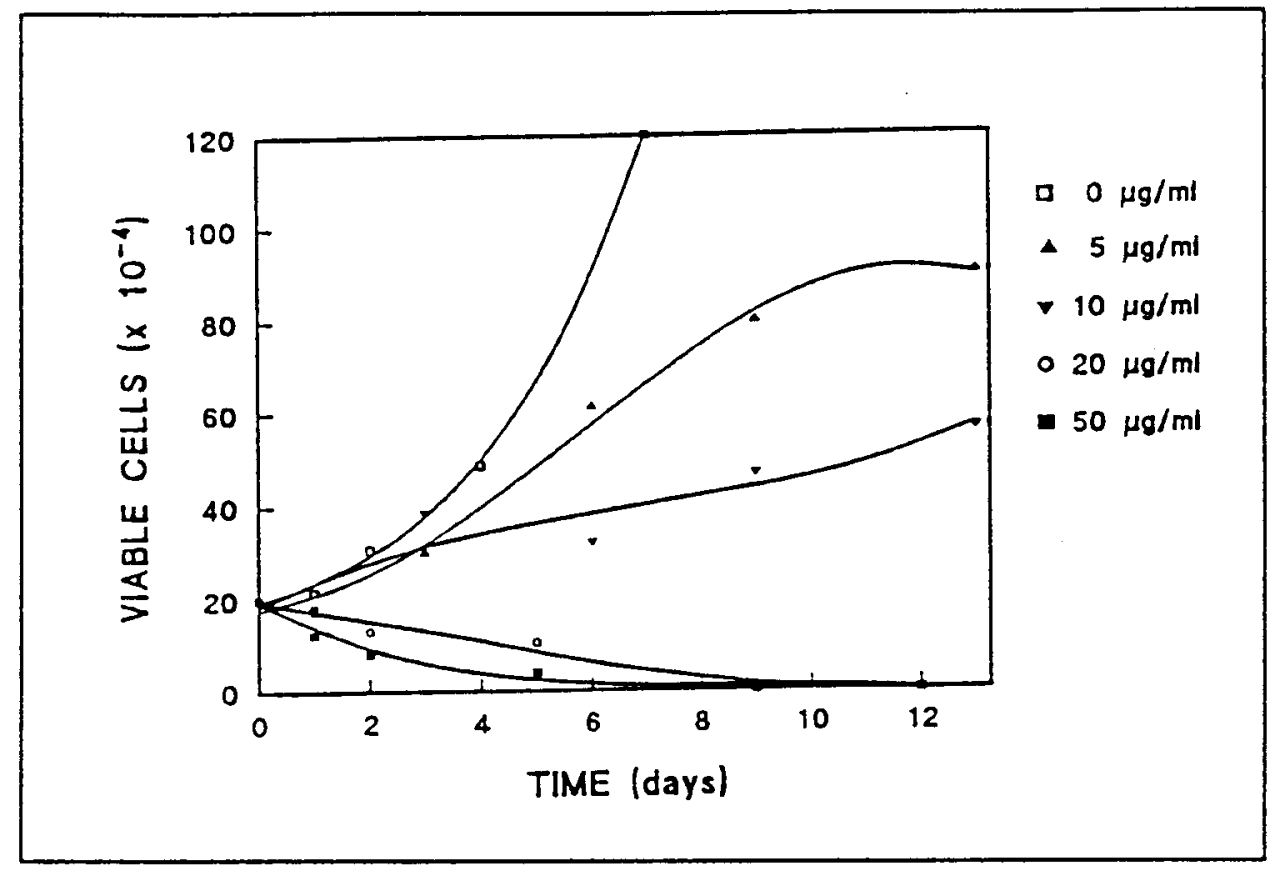

Figure 2.3

\section{Hygromycin titration}

Various concentrations of Hygromycin B were added to UCT-Mel 3 cells throughout a growth curve (starting at a cell density of $2 \times 10^{5}$ cells $/ 35 \mathrm{~mm}$ dish).

The number of viable cells was counted at each time point.

Plasmids ( $\mathrm{p} 17-\mathrm{CAT}, \mathrm{p} 17-\mathrm{tPA}_{\mathrm{s}}$ and $\mathrm{p}$ 17-tPA $\mathrm{As}_{\mathrm{as}}$ ) were prepared for transfection by purification on cesium chloride gradients, linearizing with Bgill and precipitating with ethanol. UCT-Mel 3 cells (47') were washed in HEPES buffered saline (HBS) $\mathrm{pH} 7.04$ and then resuspended at $5 \times 10^{6} / \mathrm{ml}$ in HBS containing plasmid at 20 $\mu \mathrm{g} / \mathrm{ml}$. Cells were incubated on ice for $15 \mathrm{~min}$ before transferring $0.4 \mathrm{ml}$ of the suspension to a sterile electroporation chamber, where they were exposed to a high voltage pulse (1100 V) that was empirically determined as that which killed $75 \%$ of cells (133). Cells were then incubated on ice for $15 \mathrm{~min}$, transferred to a $100 \mathrm{~mm}$ dish containing $10 \mathrm{ml} \mathrm{RP} 10$ and grown for 3 days without selection. Cells were then detached from the dishes and replated at various dilutions in RP10 containing Hygromycin at $50 \mu \mathrm{g} / \mathrm{ml}$. Cells were fed twice weekly with fresh Hygromycin containing medium. 
It was not possible to pick single cell clones from the selected dishes of adherent cells because of the significant number of floating cells present in the cultures. For this reason I cloned the cells in soft agar (A.16). Hygromycin was removed from the cultures before cloning and then replaced when clones were transferred into $35 \mathrm{~mm}$ dishes.

\section{CAT assay}

Cell lysates were prepared from both p17-CAT transfected cells (after three weeks of Hygromycin selection) and parental UCT-Mel 3 cells and assayed for CAT activity (A.25), by measuring the transfer of ${ }^{14} \mathrm{C}$ from ${ }^{14} \mathrm{C}$-chloramphenicol to acetyl Co-A.

\section{PA release by transfected UCT-Mel3 cells}

Cells were plated in duplicate in 24 well plates at densities of $5 \times 10^{4}$ and $10^{5}$ cells per well. The following day, serum free medium was added ( $500 \mu \mathrm{l} /$ well) and then collected after $24 \mathrm{hr}$. Samples were assayed using a chromogenic assay (A.30), with a tPA standard curve. Values were expressed as units $/ 10^{6}$ cells $/ 24 \mathrm{hr}$ ) and plotted against cell number (log scales).

\section{PCR}

Three primers were designed with the aid of the GCG Primer program (table 2.1). One primer, targeted to the CMV promoter region was used as forward primer for P17-CAT and p17-tPAs with the reverse primer targeted to the poly A region. This primer pair thus amplified the entire cDNA sequence. In order to amplify a part of the antisense construct, a primer specific for a site within the 5 ' end of the IPA gene was used as forward primer, while the poly A primer was used as reverse primer (see fig. 2.2B). Standard concentrations of dNTP's and primers (A.26) 
were used for all $\mathrm{PCR}$ reactions and $\mathrm{MgCl}_{2}$ concentration was optimized for each primer pair. In all cases an initial denaturation step $\left(95^{\circ} \mathrm{C}\right.$ for $\left.180 \mathrm{sec}\right)$ was performed. Cycling conditions were determined empirically for the two different primer pairs.

Cycling conditions for CMV/poly A primer pair:

$\left.\left.\left.\begin{array}{l}95^{\circ} \mathrm{C}-180 \mathrm{~s} \\ 61^{\circ} \mathrm{C}-30 \mathrm{~s} \\ 72^{\circ} \mathrm{C}-30 \mathrm{~s}\end{array}\right\} \times \begin{array}{l}95^{\circ} \mathrm{C}-30 \mathrm{~s} \\ 61^{\circ} \mathrm{C}-30 \mathrm{~s} \\ 72^{\circ} \mathrm{C}-30 \mathrm{~s}\end{array}\right\} \times \begin{array}{l}95^{\circ} \mathrm{C}-30 \mathrm{~s} \\ 58^{\circ} \mathrm{C}-30 \mathrm{~s} \\ 72^{\circ} \mathrm{C}-30 \mathrm{~s}\end{array}\right\} \times 25$

Cycling conditions for TPA/poly A primer pair:

$\left.\left.\left.\begin{array}{l}95^{\circ} \mathrm{C}-180 \mathrm{~s} \\ 61^{\circ} \mathrm{C}-30 \mathrm{~s} \\ 72^{\circ} \mathrm{C}-60 \mathrm{~s}\end{array}\right\} \times 1 \quad \begin{array}{l}95^{\circ} \mathrm{C}-30 \mathrm{~s} \\ 61^{\circ} \mathrm{C}-30 \mathrm{~s} \\ 72^{\circ} \mathrm{C}-60 \mathrm{~s}\end{array}\right\} \times \begin{array}{l}95^{\circ} \mathrm{C}-30 \mathrm{~s} \\ 58^{\circ} \mathrm{C}-30 \mathrm{~s} \\ 72^{\circ} \mathrm{C}-60 \mathrm{~s}\end{array}\right\} \times 25$

Table 2.1. PCR primers

\begin{tabular}{|l|l|l|l|l|l|c|}
\hline ID & $\begin{array}{l}\text { SEQUENCE } \\
\left(5^{\prime}-3^{\prime}\right)\end{array}$ & $\begin{array}{l}\text { TM } \\
\left({ }^{\prime}()\right.\end{array}$ & GC\% & $\begin{array}{l}\text { SELF- } \\
\text { COMP }\end{array}$ & $\begin{array}{l}3{ }^{\prime}- \\
\text { COMP }\end{array}$ & - MER \\
\hline CMV & AACAACTCCGCCCCATTGAC & 64.4 & 55 & 3 & 1 & 20 \\
POLY A & CACCTCCCCCTGAACCTGAA & 64.6 & 60 & 2 & 1 & 20 \\
TPA & TGAAACACCTTGGCTCGCTG & 64.7 & 55 & 2 & 2 & 20 \\
\hline
\end{tabular}

parameters for GCG " primer":

length $=17-28$ bases

$(\mathrm{G}+\mathrm{C}) \%=55-60$

$T_{m}=60-65 \%$

3'-complementarity' $<3$

self-complementarity $<4$ 

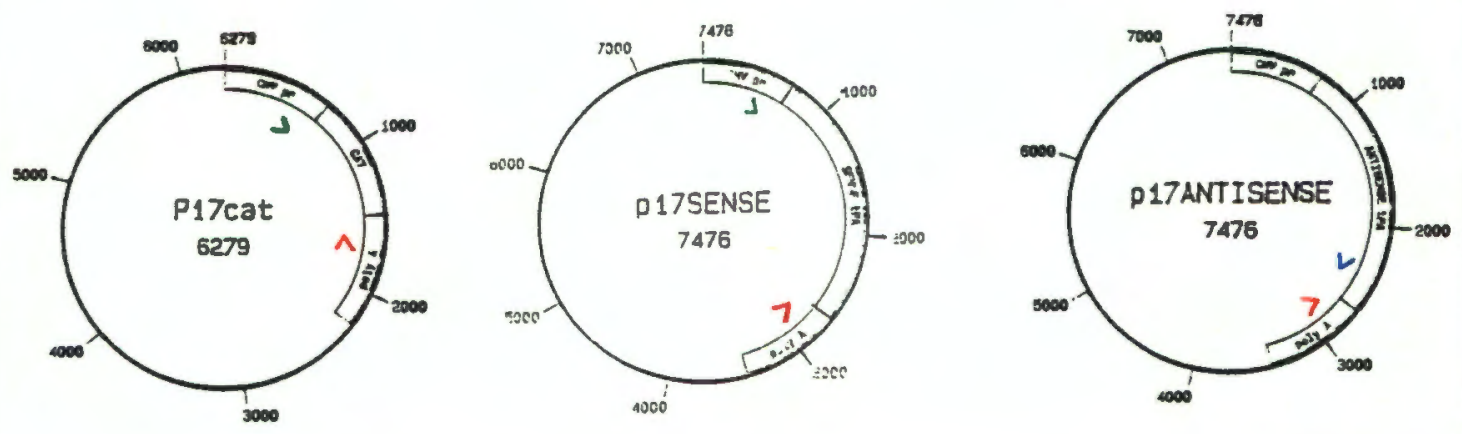

Figure 2.2B Diagram showing the positions of primers used for PCR amplification of p17-CAT, p17-tPAs and p17-tPAas

$Y=$ CMV, $\quad\rangle=$ POLYA, $\quad\rangle=$ tPA

\section{Ribozyme construction}

The tPA sequence was searched for GTC triplets and the sequences flanking each site were added to the ribozyme loop sequence and their proposed secondary structure analyzed using the Genetics Computer Group (GCG) "Squiggles" program. All sequences which did not assume the correct folding required for ribozyme activity were discounted. Position 577 within the tPA gene was finally chosen as a suitable ribozyme target site. The ribozyme sequence (fig. 2.4A) was synthesized (Prof. D. Botes, Dept. Biochemistry, UCT) as two complementary oligonucleotides, incorporating restriction enzyme cohesive ends (5'-HindIII, 3'-BamHI) for cloning purposes. The oligonucleotides were hybridized by mixing, heating to $90^{\circ} \mathrm{C}$ and cooling slowly. The ribozyme sequence was then cloned into the BamHI and HindIII sites of a transcription vector (pSP64, Promega), from which transcripts could be produced for testing ribozyme activity in vitro. The sites were also suitable for cloning into an expression vector for transfection purposes. 
A

RIBOZYME SEQUENCE

BamHI

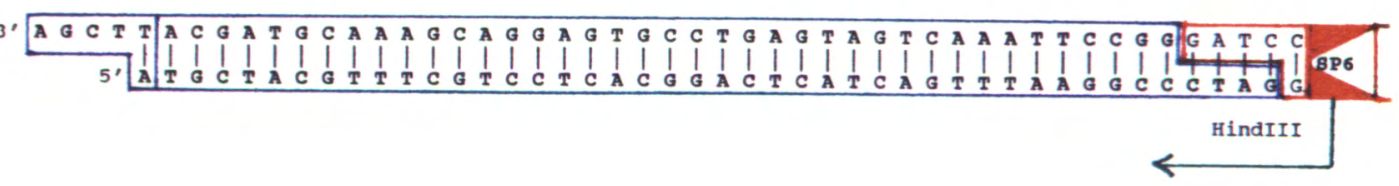

B

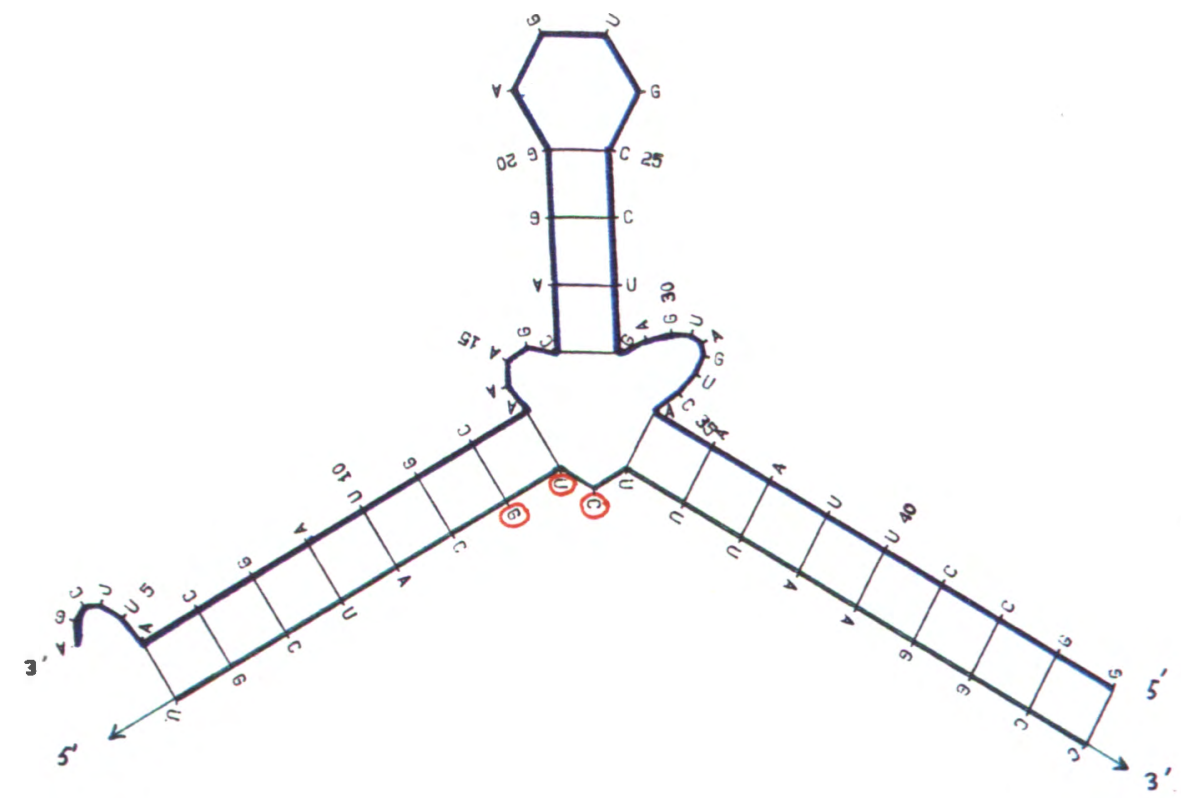

\section{Figure 2.4}

\section{A. Sequence of the anti-tPA ribozyme oligonucleotides}

Sequence of the ribozyme oligonucleotlde sequence which was cloned into the HindIII and BamHI sites of pSP64. The 5' end was ligated adjacent to the SP6 promoter of pSP64, from which the ribozyme RNA was transcribed. The recombinant pSP64-RIB was linearized at the BamHl site prior to transcription.

\section{B. Secondary structure of the anti-tPA ribozyme}

Predicted hammerhead structure of the ribozyme RNA (blue stand) annealed to its target IPA mRNA sequence (green strand). The GUC cleavage site at position 577 within the IPA mRNA is shown in red. The plot was generated by the GCG "Squiggles" program using the output from Fold. 


\section{Cloning of tPA gene into PGEM 1}

The $1976 \mathrm{bp}$ BgIll tPA fragment prepared from pW349F was ligated into the BamHI site of PGEM 1 and transformed into competent E.Coli. Minipreps were prepared to establish the presence and orientation of the inserts.

\section{Transcription}

The PGEM1-tPA and the PSP64-RIB templates were linearized by digestion with HindIII and BamHI respectively. The digests were then extracted with phenol/chloroform and ethanol precipitated. ${ }^{3} \mathrm{H}$-UTP labelled ribozyme and TPA transcripts were prepared (A.31), with SP6 and T7 RNA polymerases respectively, using the Promega Gemini kit.

For the ribozyme reaction, tPA $(0.1 \mu \mathrm{M})$ and ribozyme $(3 \mu \mathrm{M})$ transcripts were combined in $50 \mathrm{mM}$ Tris. Cl (pH 8.0), $20 \mathrm{mM} \mathrm{MgCl}$, RNAsin (2000 U/ml), and incubated at $50^{\circ} \mathrm{C}$ for $30 \mathrm{~min}$. Samples were then electrophoresed on a $4 \%$ denaturing polyacrylamide/urea gel which was treated as described (A.30) and exposed to $\mathrm{x}$-ray film.

\section{Isolation and analysis of UCT-Mel 3 clones}

Single cell clones of the UCT-Mel 3 cell line were obtained by cloning in soft agar (A.16). Growth curves were performed for each clone (A.17).

\section{Plasminogen activator release}

Conditioned medium (A.18) was collected from UCT-Mel 3 clones at densities of $10^{5}, 2 \times 10^{5}$ and $10^{6}$ cells $/ 60 \mathrm{~mm}$ dish (plated in triplicate) and assayed in the 125 fibrin assay (A.7), using a uPA standard curve. Samples were diluted ten-fold before assay. 


\section{PAI-1 ELISA}

UCT-Mel 3 conditioned media (undiluted) were tested for PAl-1 antigen using the American Diagnostica PAI-1 ELISA kit (\#822/5).

\section{tPA receptor}

UCT-Mel 3 cells were acid treated (A.31) to remove cell-surface associated tPA, washed and then $10^{6}$ cells were incubated $\left(2 \mathrm{hr}, 4^{\circ} \mathrm{C}\right)$ with increasing concentrations of TPA in $200 \mu \mathrm{l}$ of binding medium (Hepes buffered RPMI containing $0.5 \% \mathrm{BSA}$ ). The cells were washed 4 times in binding medium to remove unbound tPA and then acid treated. Neutralized eluates were collected and assayed for tPA activity in the $125 \mid$-fibrin plate assay.

\section{Results}

\section{Sense and antisense plasmids}

The 1976 bp Bgill fragment of the tPA gene was successfully cloned into the p17 vector in both sense and antisense orientations. Recombinant clones were checked by simultaneous digestion with Bglll and Smal, which yielded fragment sizes of 6175 and 1296 for sense t-PA (p17-tPAs), 5099 and 2372 for antisense tPA (p17-tPA $A_{a s}$ ) and a single band of 6270 for no insert (fig. 2.5). Plasmids p17$\mathrm{tPA}_{\mathrm{s}}$ and $\mathrm{p} 17-\mathrm{tPA}_{\mathrm{as}}$ were then amplified and purified by $\mathrm{CsCl}$ purification (A.22) in preparation for transfections. 


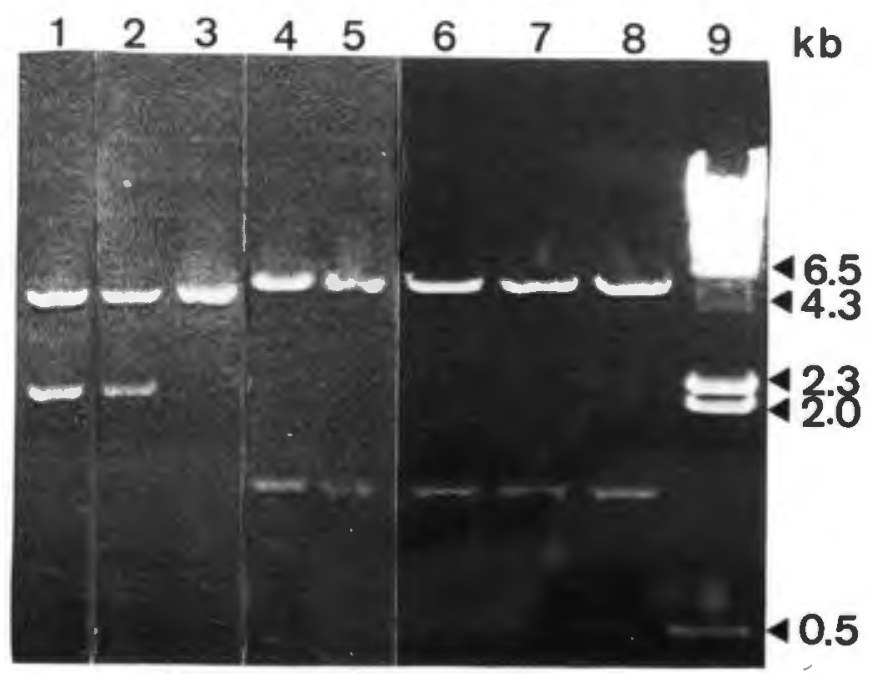

Figure 2.5

Orientation of p17-tPA insert

Putative recombinant plasmid minipreps were digested with Smal and Bglll in order to determine the orientation of the IPA insert. Digestion yielded bands of 6175 and 1296 bp for sense clones (lanes 4-8) and bands of 5099 and 2372 bp for antisense clones (lanes 1,2). $\lambda$ /Hindlll size markers were run in lane 9 . Lane 3 represents p17 lacking an insert.

\section{Transfection by electroporation}

CAT expression was measured in lysates prepared from UCT-Mel 3 cells transfected with p17-CAT, which had been under Hygromycin selection (50 $\mu \mathrm{g} / \mathrm{ml}$ ) for 3 weeks. Lysates prepared from untransfected cells were used as a negative control. Appreciable levels of CAT were measured in CAT transfected cells (0.06 units) and untransfected cells were negative (fig. 2.6). Once the expression of the CAT gene under the CMV promoter had been confirmed, I went on to transfect p17-tPA and p17-tPA as, with subsequent Hygromycin selection. Hygromycin resistant cells appeared as islands of growth after approximately three weeks, however the presence of many floating cells within the UCT-Mel 3 
cultures resulted in the formation of rather untidy and indistinct clones. Since it was impossible to pick single clones using cloning rings, the selected cells were cloned in soft agar. Cells which had been electroporated in the absence of DNA were selected with Hygromycin in parallel and these were also found to produce resistant clones.

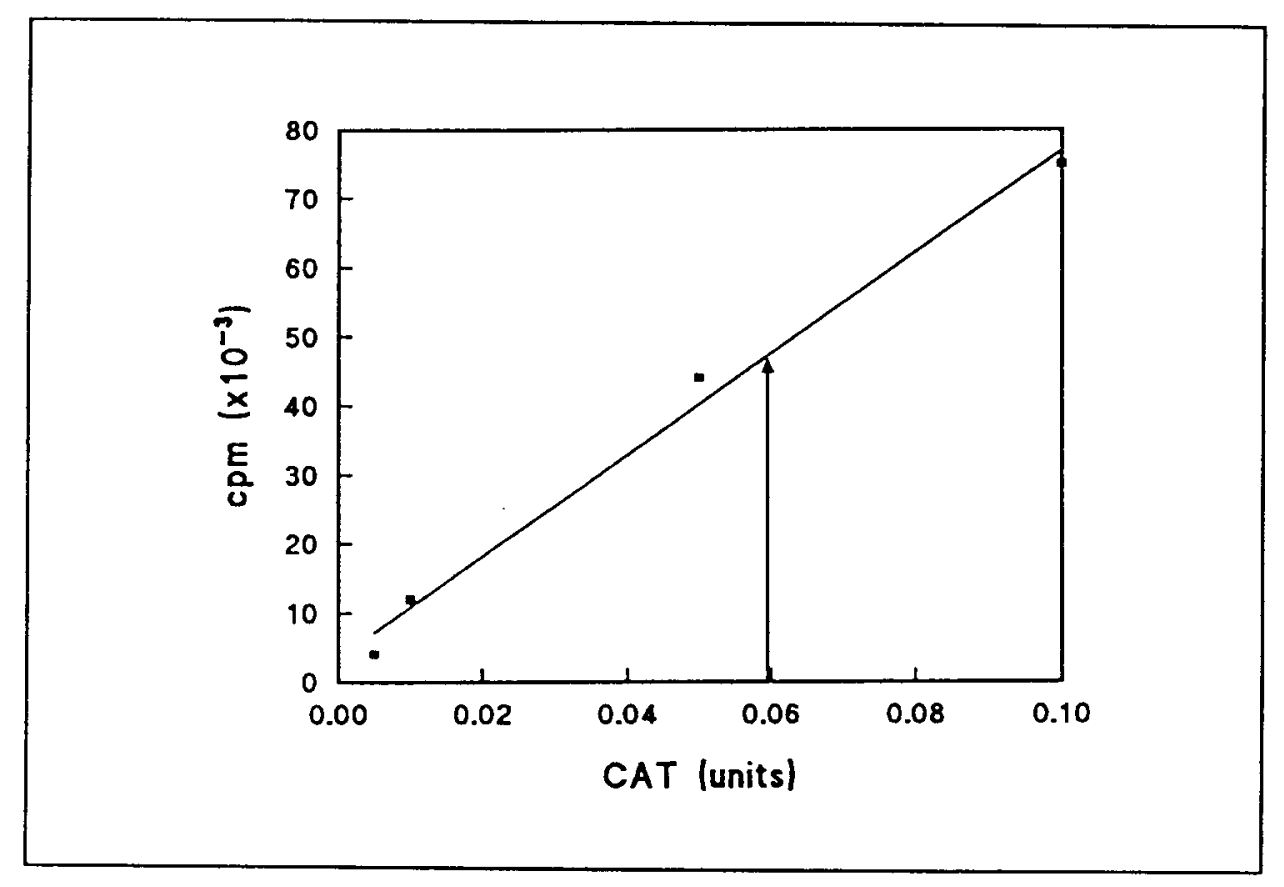

Figure 2.6

\section{CAT assay standard curve}

Standard curve obtained from dilutions of a standard CAT preparation. The bar indicates the value of 0.06 extrapolated from the cpm obtained from assaying 50 $\mu l$ of a $150 \mu$ l cell lysate prepared from UCT-Mel 3 cells transfected with p17-CAT and subsequent Hygromycin selection. Thus CAT produced from a confluent 100 $\mathrm{mm}$ dish corresponds to 0.18 units.

\section{Cloning of transfectants}

Agar cultures are not fed freshly, thus Hygromycin which should be replenished every 3-5 days was omitted. Clones were picked after 14 days and transferred to microtiter plates. Clones were successfully grown from the p17-tPAs (5 clones) and $\mathrm{p} 17-\mathrm{tPA}_{\mathrm{as}}$ (15 clones) transfected cultures respectively and frozen down. 


\section{tPA release by electroporated clones}

Release of tPA by cells grown from Hygromycin-resistant clones that had been electroporated with p17-tPAas was measured in the hope that I would find stable transfectants that no longer synthesized tPA (table 2.2).

Table 2.2. Plasminogen activator release by UCT-Mel 3 cells transfected with p17-tPAas

\begin{tabular}{|l|l|c|c|c|}
\hline \multirow{2}{*}{ CLONE } & PA $(1)$ & \multicolumn{3}{|c}{ REGRESSION PARAMETERS $(2)$} \\
\hline \multirow{2}{*}{ PARENT } & 63.979 & $-0.638 \pm 0.031$ & $4.804 \pm 0.152$ & 0.984 \\
1 & 35.550 & $-0.839 \pm 0.099$ & $5.498 \pm 0.474$ & 0.993 \\
4 & 30.660 & $-0.472 \pm 0.114$ & $3.705 \pm 0.544$ & 0.972 \\
5 & 63.681 & $-0.408 \pm 0.086$ & $3.721 \pm 0.402$ & 0.959 \\
7 & 57.483 & $-0.540 \pm 0.090$ & $4.297 \pm 0.432$ & 0.973 \\
8 & 57.429 & $-0.429 \pm 0.160$ & $3.775 \pm 0.755$ & 0.884 \\
9 & 59.952 & $-0.707 \pm 0.145$ & $5.100 \pm 0.679$ & 0.980 \\
11 & 16.330 & $-0.495 \pm 0.004$ & $3.539 \pm 0.021$ & 0.999 \\
15 & 42.846 & $-0.106 \pm 0.110$ & $2.131 \pm 0.519$ & 0.563 \\
17 & 24.222 & $-0.014 \pm 0.090$ & $1.451 \pm 0.421$ & 0.105 \\
18 & 24.560 & $-0.333 \pm 0.114$ & $2.955 \pm 0.541$ & 0.947 \\
19 & 49.345 & $-0.446 \pm 0.126$ & $3.789 \pm 0.580$ & 0.929 \\
20 & 55.213 & $-0.339 \pm 0.095$ & $3.335 \pm 0.450$ & 0.929 \\
\hline
\end{tabular}

(1) PA release calculated from regression for a cell density of $5 \times 10^{4}$ cells $/ 60 \mathrm{~mm}$ dish

(2) Regression parameters given for the equation:

$(\log y)=m(\log x)+c$

$y=P A$ release $/ 10^{\varepsilon}$ cells $/ 24 \mathrm{hr}$

$\mathrm{x}=$ cells $/ 60 \mathrm{~mm}$ dish

$r=$ correlation coefficient 
Due to the inverse relationship between PA release and cell density, (see fig. 2.12), the values obtained were converted to units $/ 10^{6} \mathrm{cells} / 24 \mathrm{hr}$ and plotted against cell density. Log scales were used in order to obtain a linear relationship. The results (table 2.2) showed very variable levels for tPA release ranging from 16 to 63 units $/ 10^{6}$ cells $/ 24 \mathrm{hr}$ (calculated for a cell density of $5 \times 10^{4}$ cells $/ 16 \mathrm{~mm}$ well). I found no clones in which release of the enzyme had been totally abolished, although in some clones the PA activity was lower than in the parental UCT-Mel 3.

\section{PCR analysis of electroporated clones}

I used the primers described in the methods section to analyze the transfected Hygromycin resistant clones by PCR with the results shown in figs. 2.7 and 2.8.

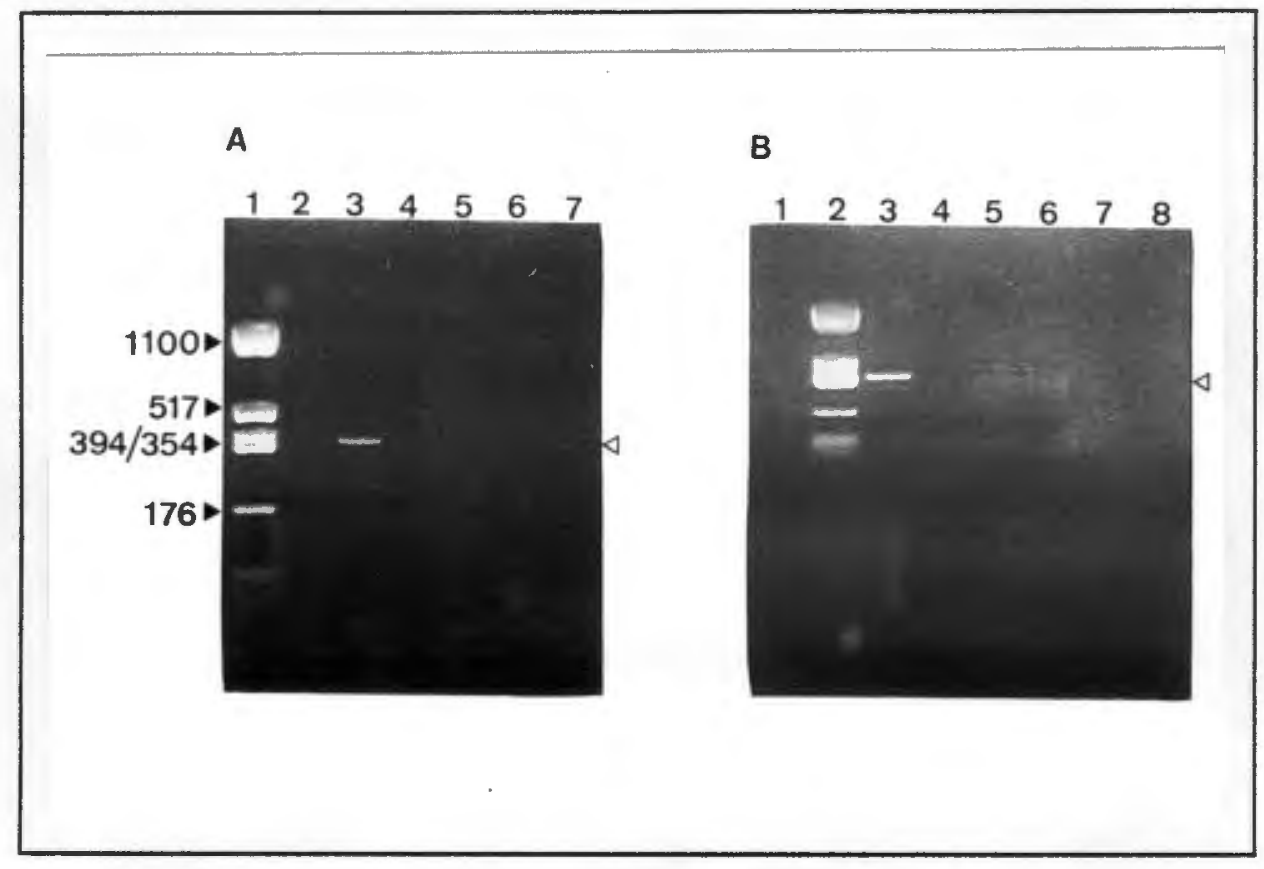

Figure 2.7

PCR detection of p17-tPAas in cell lysates of transfected UCT-Mel 3 clones PCR products were electrophoresed on a $1.5 \%$ agarose gel

A lane 1, pGEM1/Hinfl size markers; lane 2, no DNA control; lane 3, p17tPAas plasmid as positive control; lane 4-7, antisense clones

B lane 2, pGEM/Hinfl; lane 3, p17-tPAas; lanes 1, 4-8, antisense clones 
Of the clones electroporated with p17-tPA, both those tested contained the plasmid (fig. 2.8). In none of those electroporated with p17-tPAas was I able to demonstrate transfected DNA (fig. 2.7). PCR amplification of the p17-CAT transfected cells produced the correct band (fig. 2.8), as expected from the CAT assay result.

A

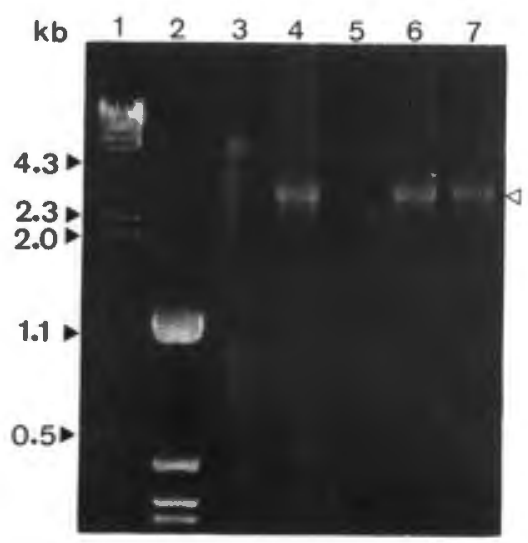

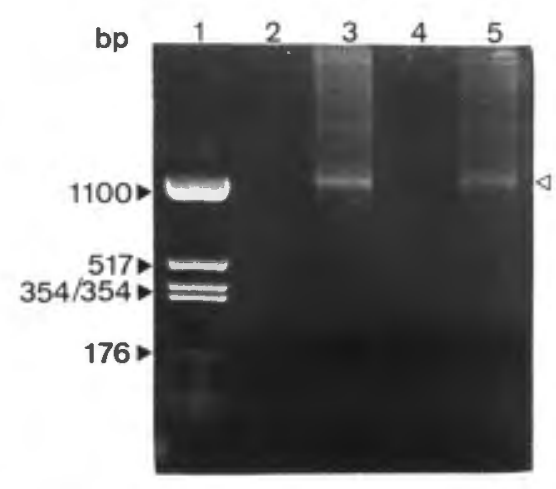

Figure 2.8

PCR detection of P17-tPAs and p17-CAT in cell lysates of transfected UCTMel 3 clones

PCR amplification products were electrophoresed on a 1.5\% agarose gel A lane 1, $\lambda$ /HindIII markers; lane 2, pGEM/Hinfl markers; lane 3, no DNA control; lane 4, p17-tPAs plasmid; lane 5, untransfected UCT-Mel 3; lane 6, p17-tPA transfected clone 2; lane 7, p17-tPAs transfected clone 29.

B. lane 1, pGEM/Hinfl markers; lane 2, no DNA control; lane 3, p17-CAT plasmid; lane 4, untransfected UCT-Mel 3; lane 5, p17-CAT transfected UCT-Mel 3 DNA. 


\section{Ribozyme construction}

The ribozyme targeted to position 577 of tPA mRNA was successfully cloned into the pSP64 vector. This was confirmed by digesting transformants with HindIII and BamHI. Digestion of recombinants released the 44 bp ribozyme fragment, compared to $27 \mathrm{bp}$ for the vector alone (representing a fragment of the multiple cloning site). These bands were too small to be visualized on an agarose gel and hence were separated on a $20 \%$ nondenaturing polyacrylamide gel (fig. 2.9).

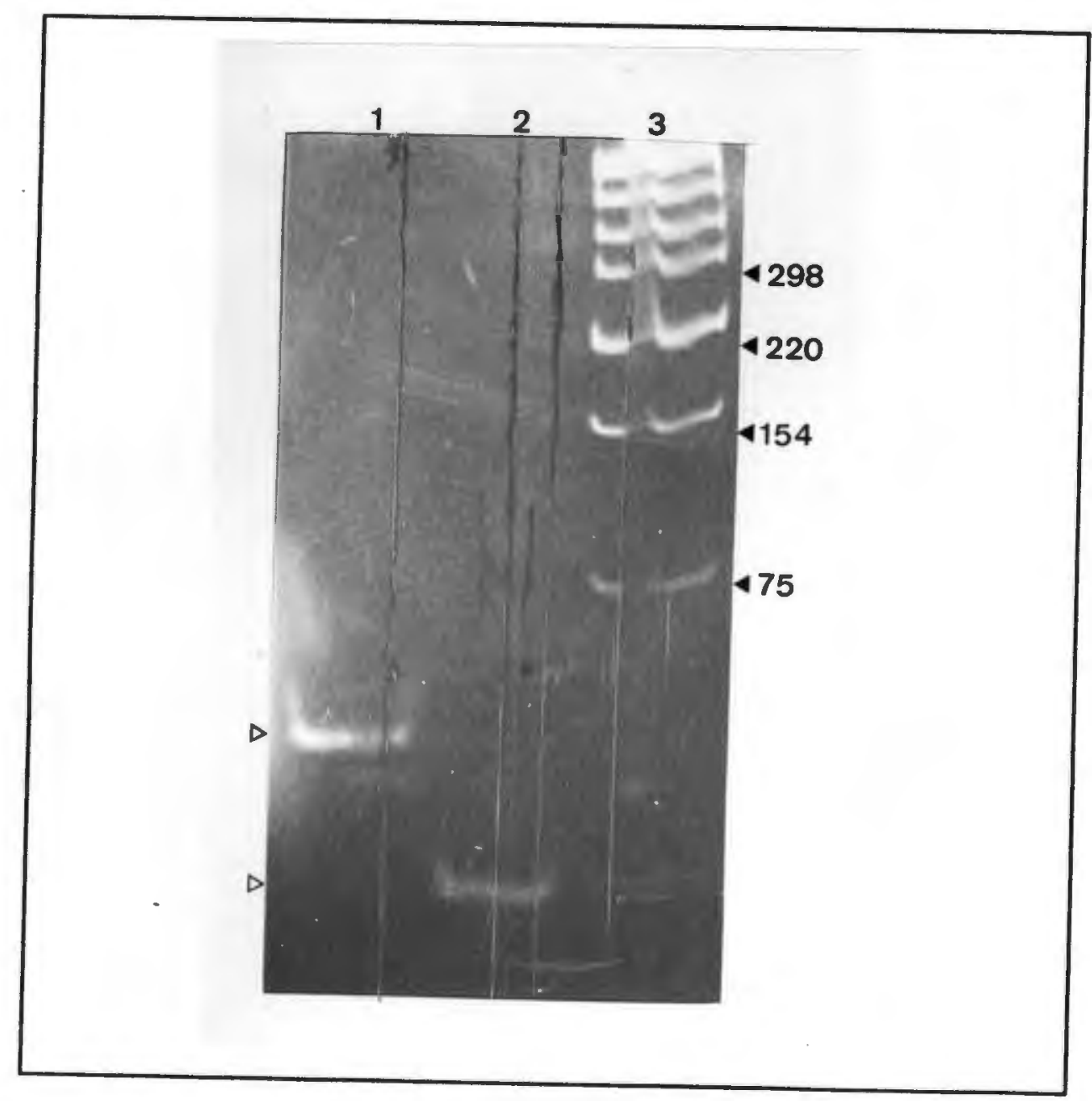

Figure 2.9

Cloning of the ant-tPA ribozyme into pSP64 was confirmed by digestion with HindIII and BamHI. The digest was electrophoresed on a $20 \%$ non-denaturing gel. lane 1. pSP64-RIB digested with HindIII and BamHI (44 bp). lane 2, pSP64 digested with HindlII and BamHI (27 bp). lane 3, pGEM/Hinfl marker 


\section{tPA template preparation}

Digestion of the transformants with Smal produced bands of $3307 \mathrm{bp}$ and 1532 bp for sense recombinant plasmids (fig. 2.10) compared to a single 2998 bp band for vector alone. The plasmid DNA from a PGEM 1-tPA $s$ containing colony was amplified and purified over a $\mathrm{CsCl}$ gradient and used as a template for transcription from the $T 7$ promoter.

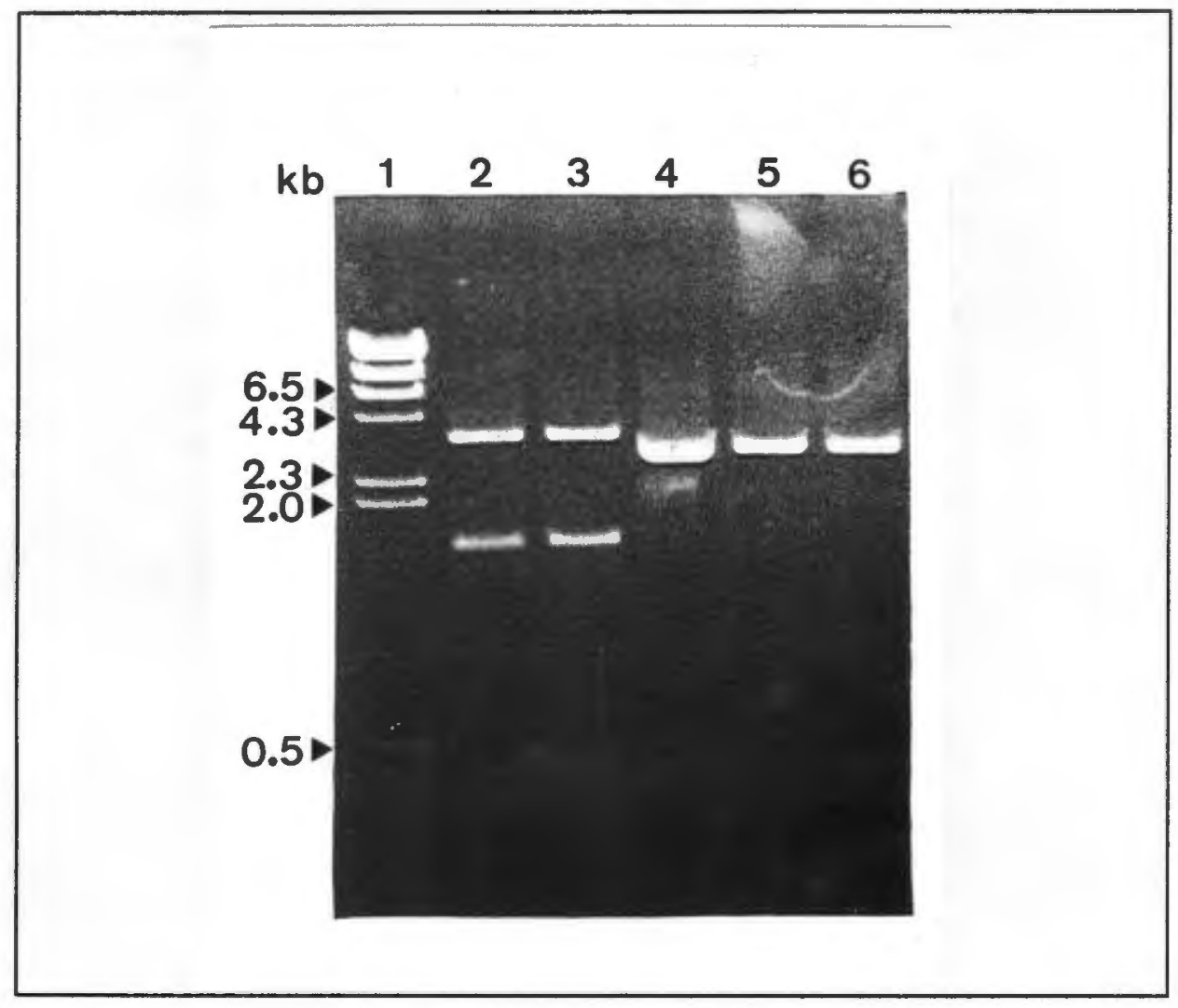

Figure 2.10

Orientation of PGEM1-tPA insert

The tPA/Bglll fragment (2000 bp) was cloned into the Bglll site of pGEM1.

Orientation of the fragment was determined in putative recombinant minipreps by digestion with Smal.

lane 1, $\lambda$ /HindIII markers; lanes 2 and 3, sense oriented recombinants (sizes 3307 and $1693 \mathrm{bp}$ ); lanes 4-6, non-recombinants (2998 bp). 


\section{Testing of ribozyme on synthetic tPA RNA substrate}

The ${ }^{3} \mathrm{H}$-labelled ribozyme and tPA transcripts were found to be intact and of the correct size (44 bp and 1100 bp respectively) after denaturing PAGE and subsequent auto radiography (fig. 2.11). The tPA transcript showed some evidence of either premature termination or degradation in the form of lower MW bands. After incubation of the IPA substrate with the ribozyme followed by electrophoresis and autoradiography, no digestion of the tPA transcript was observed.

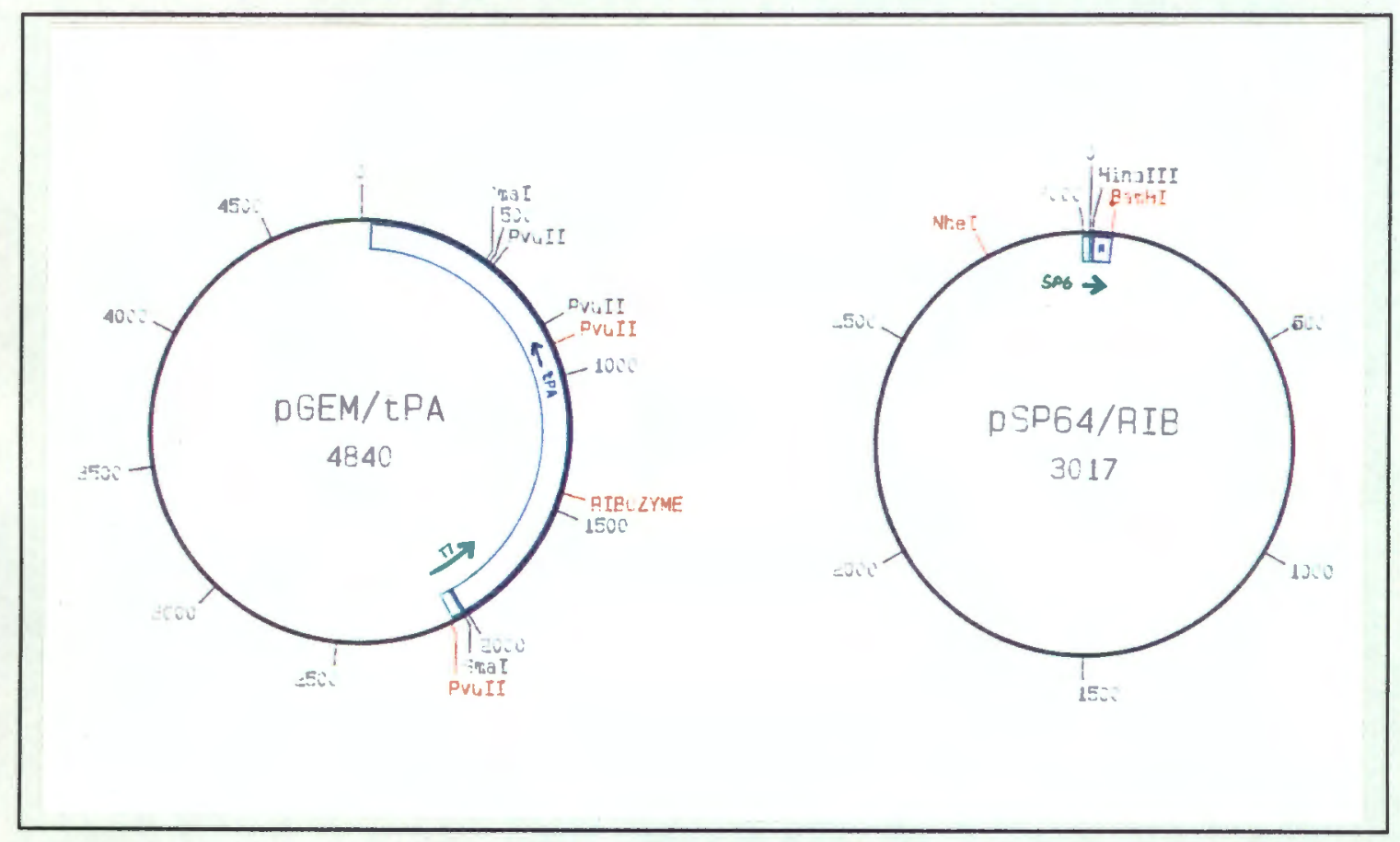

Figure 2.11A

Transcription of ribozyme and tPA template

Diagrammatic representation of pSP64-RIB and pGEM1-tPA:

pSP64-RIB was digested with BamHI and Nhel and the fragment containing the SP6 promoter and ribozyme insert was gel purified. The ribozyme was then transcribed using SP6 RNA polymerase. pGEM1-tPA was digested with Pvull and the fragment containing the 77 promoter and the $5^{\prime}$ end of the tPA sequence was gel purified. The tPA RNA was then transcribed using T7 RNA polymerase. 


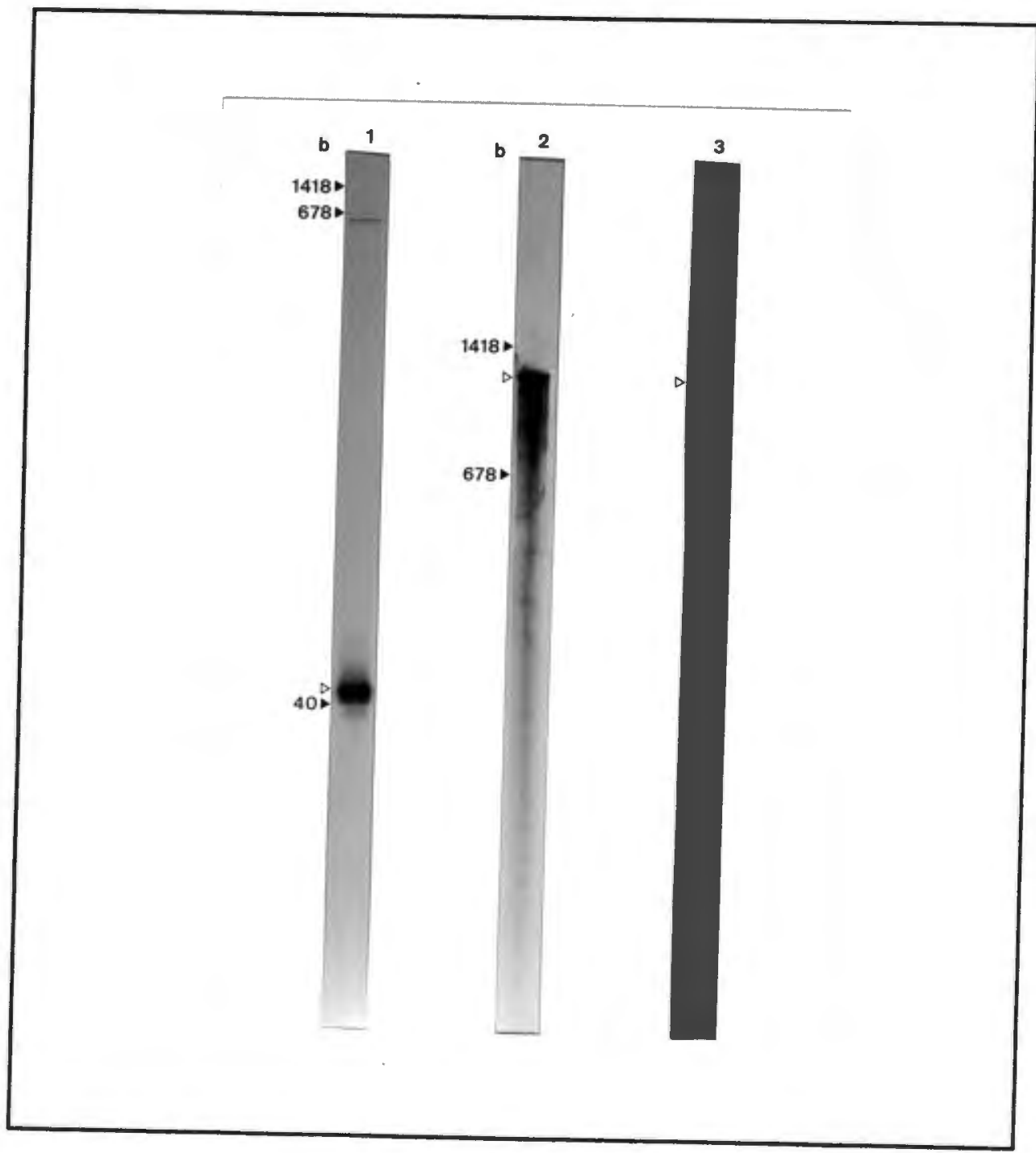

\section{Figure 2.11B}

Transcription of ribozyme and tPA template and testing for ribozyme catalysis of tPA RNA

Ribozyme and TPA mRNA were transcribed with the incorporation of ${ }^{3} \mathrm{H}-U T P$. electrophoresed on a $4 \%$ denaturing polyacrylamide gel which was then fixed, fluorographed, dried and autoradlographed.

lane 1, ribozyme transcript ( $44 \mathrm{bp})$

lane 2, tPA transcript (1195 bp)

lane 3, tPA transcript after treatment with ribozyme

The mobilities of standard transcripts produced from templates provided in the kit are Indicated. 


\section{Clonal analysis of UCT-Mel 3}

The variation in levels of tPA release seen in the Hygromycin-resistant clones indicated that UCT-Mel 3 cells are phenotypically unstable and heterogeneous. To document the extent of this variability and to correlate it, if possible, with invasiveness and metastatic potential, I prepared 20 clones from a single 40passage culture and characterized these in terms of their morphology, IPA release and doubling time. The results are presented in fig. 2.12, 2.13 and table 2.3. The non-linear relationship between $P A$ release and cell density required that results were plotted as log (units $/ 10^{6}$ cells $/ 24 \mathrm{hr}$ ) against log cell density. This produced a linear graph from which results could be calculated for a particular cell density.

As is evident from the data, clones that varied considerably in this respect could be derived from the parent culture. Morphologically, cells within any clone were fairly homogeneous at early passage. As shown in fig. 2.12, most clones grew as adherent monolayers, whereas others grew as a semi-adherent layer with many rounded but nevertheless viable cells (eg. 1D6). No pigmented cells were seen. Most grew as flattened polygonal or triangular cells, similar to the parental cells (eg. 1C5, 2A4). The more spindle shaped morphology of clone 1B4 was particularly noticeable. Other clones were distinctly dendritic with long processes (eg. 2B4, 1D3). Clones 3D3 and 1B3 were distinguished by the tendency for cells to pile up into large amorphous clumps, even when subconfluent. Another feature was size variation amongst the clones, with the existence of giant cells in some clones (eg. 1A1, 1A6, 1B3). Some of these large cells took on a very spread out, flattened appearance (1A6, marked by arrow). 

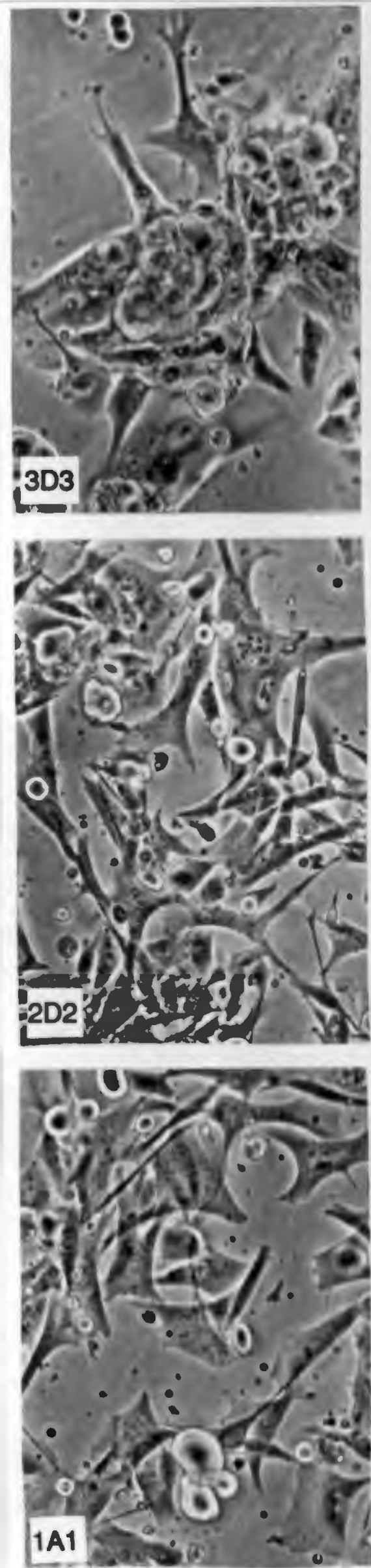
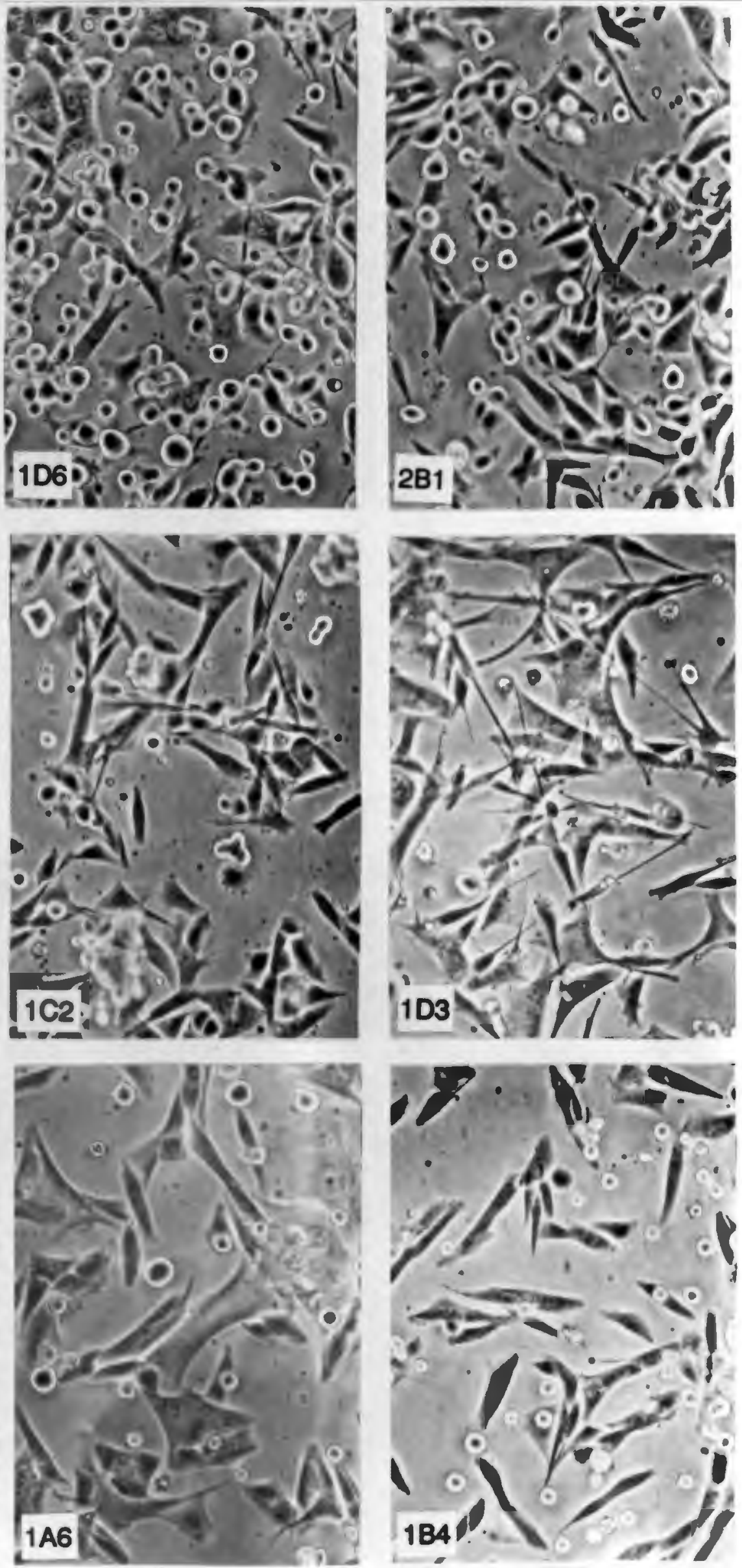

Figure 2.12A

Morphology of UCT-Mel 3 clones

UCT-Mel 3 clones were plated at a density of $10^{6}$ cells $/ 60 \mathrm{~mm}$ dish and photographed at $100 \mathrm{x}$

magnification on a phase contrast microscope. 

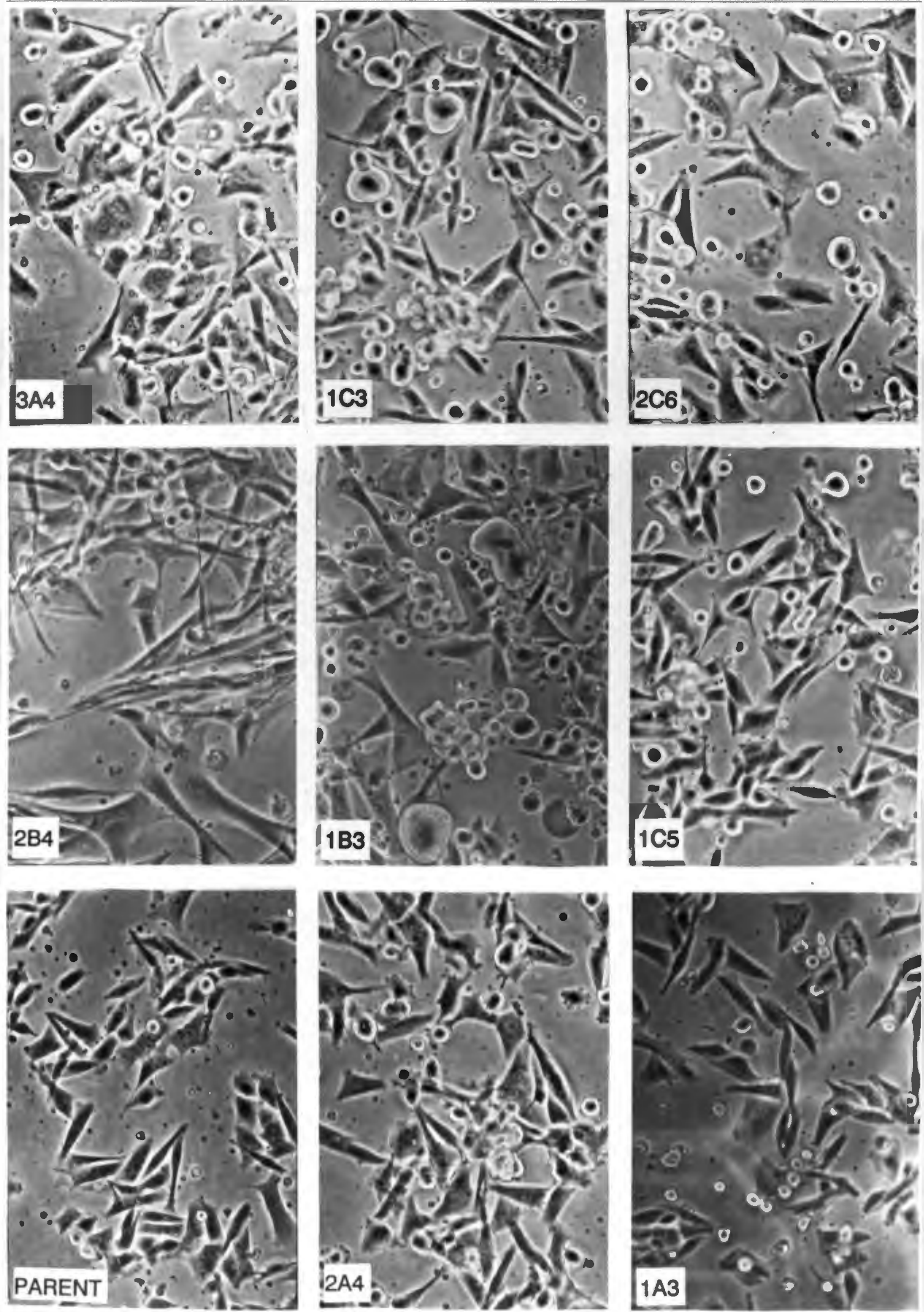

Figure 2.12B

Morphology of UCT-Mel 3 clones

UCT-Mel 3 clones were plated at a density of $10^{6}$ cells $/ 60 \mathrm{~mm}$ dish and photographed at $100 \mathrm{x}$

magnification on a phase contrast microscope. 
Table 2.3. Plasminogen activator production by UCT-Mel 3 clones.

\begin{tabular}{|c|c|c|c|c|c|c|}
\hline CLONE & DT (hr) & $\mathrm{PA}$ (1) & \multicolumn{4}{|c|}{ REGRESSION PARAMETERS (2) } \\
\hline & & & $\mathbf{M}$ & & C & $r$ \\
\hline $1 \mathrm{AI}$ & 100 & 14.351 & $-0.691 \pm$ & $=0.043$ & $4.612 \pm 0.226$ & 0.987 \\
\hline $1 \mathrm{~A} 3$ & 48 & 7.197 & $-0.356 \pm$ & 0.040 & $2.637 \pm 0.216$ & 0.959 \\
\hline $1 \mathrm{~A} 6$ & 61 & 7.609 & $-0.463 \pm$ & \pm 0.045 & $3.195 \pm 0.249$ & 0.968 \\
\hline IB3 & 66 & 14.991 & $-0.701 \pm$ & \pm 0.044 & $4.679 \pm 0.244$ & 0.986 \\
\hline IB4 & 38 & 7.395 & $-0.702=$ & \pm 0.073 & $4.380 \pm 0.408$ & 0.964 \\
\hline $1 C 2$ & 71 & 20.151 & $-0.770 \pm$ & \pm 0.069 & $5.155 \pm 0.372$ & 0.973 \\
\hline 105 & 58 & 7.161 & $-0.651 \pm$ & \pm 0.117 & $4.111 \pm 0.639$ & 0.928 \\
\hline 1D3 & 50 & 7.290 & $-0.650=$ & \pm 0.103 & $4.115 \pm 0.560$ & 0.923 \\
\hline $1 D 6$ & 83 & 10.224 & $-0.679 \pm$ & \pm 0.061 & $4.404 \pm 0.326$ & 0.973 \\
\hline $2 A 4$ & 69 & 7.643 & $-0.391=$ & \pm 0.047 & $2.840 \pm 0.255$ & 0.953 \\
\hline $2 \mathrm{~A} 5$ & 52 & 14.348 & $-0.721=$ & \pm 0.046 & $4.762 \pm 0.250$ & 0.986 \\
\hline $2 B 1$ & 35 & 16.935 & $-0.684 \pm$ & \pm 0.054 & $4.674 \pm 0.294$ & 0.979 \\
\hline $2 \mathrm{~B} 4$ & 76 & 16.009 & -0.753 & \pm 0.043 & $4.970 \pm 0.233$ & 0.989 \\
\hline $2 \mathrm{C6}$ & 57 & 12.246 & $-0.623=$ & \pm 0.065 & $4.202 \pm 0.351$ & 0.965 \\
\hline $2 \mathrm{D} 2$ & 65 & 10.879 & $-1.006=$ & \pm 0.068 & $6.068 \pm 0.375$ & 0.984 \\
\hline $3 \mathrm{~A} 4$ & 54 & 7.440 & $-0.702=$ & \pm 0.073 & $4.380 \pm 0.478$ & 0.964 \\
\hline $3 \mathrm{~B} 4$ & 58 & 12.399 & $-0.642=$ & \pm 0.022 & $4.304 \pm 0.117$ & 0.996 \\
\hline $3 \mathrm{~B} 5$ & 46 & 10.818 & $-0.508=$ & \pm 0.058 & $3.576 \pm 0.318$ & 0.958 \\
\hline 3D3 & 61 & 16.429 & $-0.561=$ & \pm 0.043 & $4.019 \pm 0.218$ & 0.980 \\
\hline MEL 3 & 55 & 3.82 & $-0.274=$ & \pm 0.048 & $1.952 \pm 0.271$ & 0.908 \\
\hline
\end{tabular}



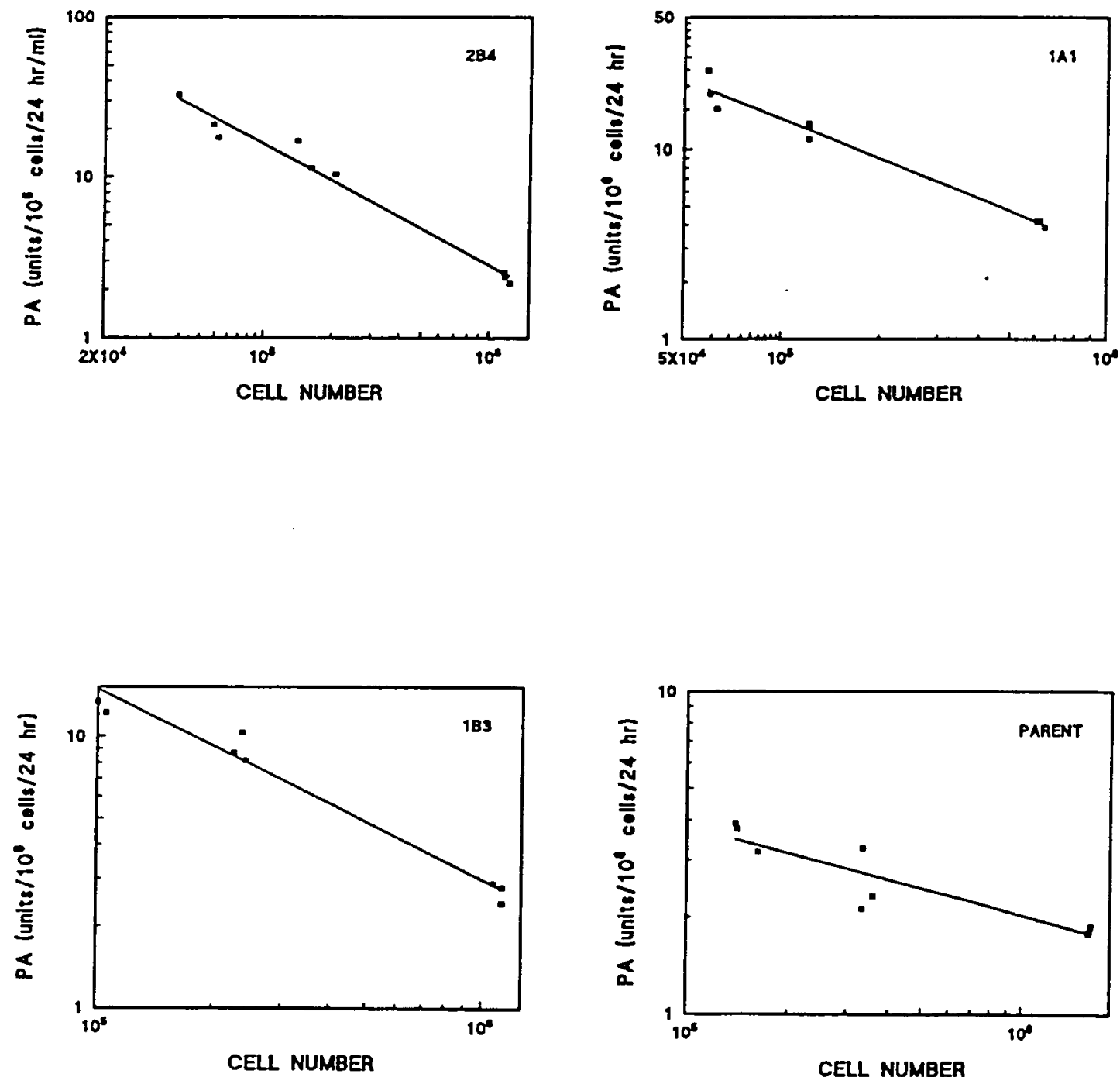

Figure 2.13

Plasminogen activator release by UCT-Mel 3 clones

PA release by UCT-Mel 3 clones was measured In the fibrin plate assay. Results were converted to units $/ 10^{6}$ cells $/ 24 \mathrm{hr}$ and plotted against cell density on a log scale to obtain a linear relationship. These graphs are representative examples.

Doubling times were distributed over the range 38 to $100 \mathrm{hr}$ (table 2.3). The rate of tPA release by each clone was consistently inversely related to cell density. Plots of log rate of enzyme release (measured as units $/ 10^{6} \mathrm{cells} / 24 \mathrm{hr}$ ) as a 
function of log cell density gave linear plots with the parameters and correlation coefficients presented in table 2.3. Typical plots showing this inverse relationship are shown in fig. 2.13. To compare PA release by different clones it was thus necessary to correct for cell density. This was done by calculating the interpolated value for the rate of tPA release corresponding to a cell density of $10^{5}$ cells $/ 60 \mathrm{~mm}$ dish. Values varied considerably from 3.82 to 20 units. No significant relationship between PA release and doubling time could be discerned.

\section{PAI-1 ELISA}

PAI-1 antigen was undetectable in all UCT-Mel 3 clone conditioned media as well as the parental line when tested in the PAI-1 ELISA (detection limit $<0.5 \mathrm{ng} / \mathrm{ml}$ ). Human serum (diluted 40-fold), used as a positive control, had a PAl-1 concentration of $2 \mathrm{ng} / \mathrm{ml}$.

\section{Cell surface receptor for tPA}

If, by analogy with the proposed mechanisms for UPA-mediated spread, tPA were to be involved in the migratory process, one would expect cells to express surface receptors for TPA.

My attempts to measure such receptors or to show saturable association of cells with enzyme using radio-labelled tPA were not at all successful. I had, perforce to use whole intact tPA for labelling and binding studies, since I did not have a well defined "receptor ligand domain", similar to the ATF of uPA to work with. Labelled tPA gave erratic results in binding studies; background counts were high and I was unable to maintain reasonably physiological conditions in the effort to reduce non-specific binding. 
I thus resorted to a technique in which UCT-Mel 3 cells were treated with acid to remove such residual enzyme as may be present. The cells were then incubated with different concentrations of tPA and washed. Bound tPA was eluted with glycine, $\mathrm{pH}$ 3.0, measured and plotted as a function of the amount of tPA added. A typical plot is shown in fig. 2.14. From the data obtained, an approximate $K_{d}$ of $4 \mathrm{nM}$ (corresponding to $50 \%$ of maximum binding) and total cellular capacity for tPA binding of 50000 molecules/cell could be estimated.

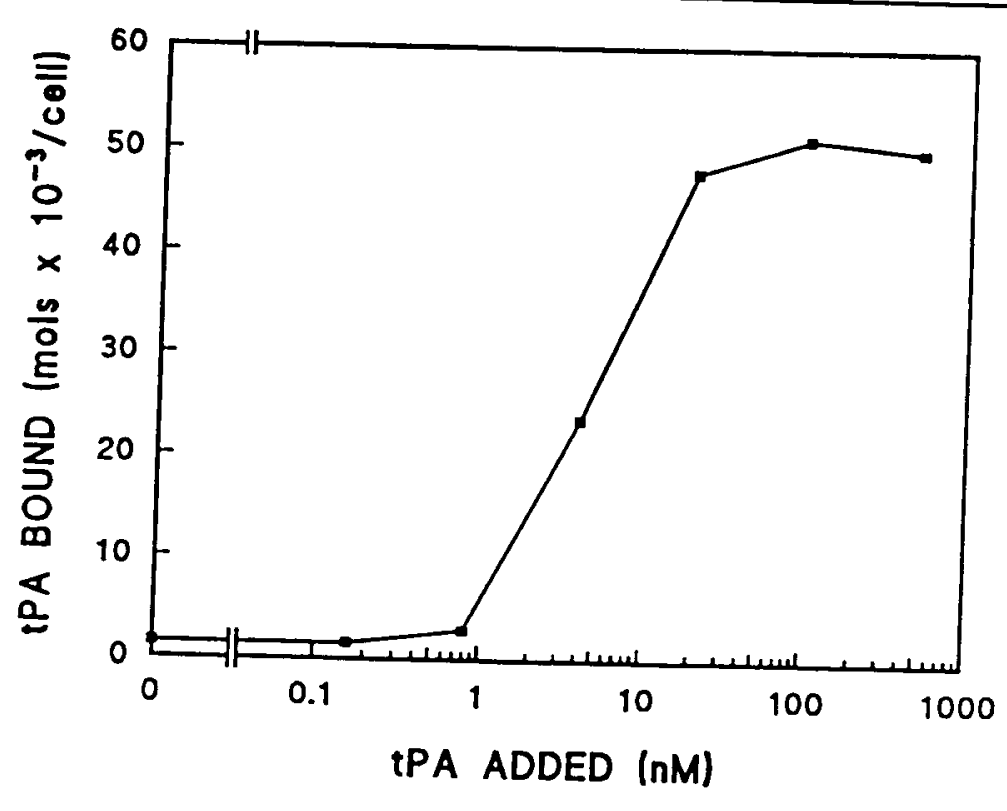

Figure 2.14

\section{Binding of tPA to the surface of UCT-Mel 3 cells}

Acid treated UCT-Mel 3 cells were incubated with various concentrations of IPA (2 $\mathrm{hr}$ at $4^{\circ} \mathrm{C}$ ). Cells were washed, eluted with acid to remove surface associated molecules, and the IPA in eluates measured with the fibrin plate assay. $50 \%$ of maximal binding occurred at approximately $4 \mathrm{nM}$. 


\section{Discussion}

The experimental strategy that I chose to define a role for IPA in the metastatic process proved to be unsatisfactory in two respects. First, I was unable to develop a line of cells in which the synthesis of tPA was abolished and, second, had I been able to do so, the failure of such cells to develop into metastasizing tumours could have reflected an irrelevant clonal difference that was unrelated to eliminated protease activity. Had, of course, such cells been as tumourigenic and metastatic as the parental line, I could have concluded that tumour-derived IPA was not involved, but such a result would have been interesting in a negative sense. It would have contributed little to an understanding of the biochemistry of invasion or spread.

I did not expect the genetic manipulation to be unsuccessful nor did it occur to me that phenotypic instability and clonal variation within an established cell line would be so pronounced. Nevertheless, the unforeseen problems provide interesting grounds for comment.

I have no explanation to offer for the failure of the ribozyme to cut the IPA transcript, save for the possibility that the site which I chose may have been obscured or unavailable for binding to the ribozyme due to secondary structure. Heidenreich et al. (134) have shown that longer substrates were $1000 x$ less efficiently cleaved by a ribozyme than oligonucleotides and also that at a particular site, cleavage of the longer substrate was much less efficient that at other sites. It is possible therefore, that I would have had more success if I had synthesized a number of ribozymes targeted to different GTC sites. In view of the fact that I could not demonstrate hydrolytic activity, I felt it would be pointless to 
proceed to the next step of cloning the ribozyme into an expression vector and transfecting the construct into melanoma cells.

The experiments in which I transfected UCT-Mel 3 cells with the anti-sense IPA construct were, perhaps, more interesting. Expression of the CAT reporter gene in transfected cells showed quite clearly that the CMV promoter in $\mathrm{p} 17$ functioned efficiently and stably. Furthermore, clones that had been electroporated with p17tPA $_{6}$ could be shown to contain the plasmid. Why then, was p17-tPA as not retained? In these particular cells, selection with Hygromycin was inefficient in the sense that they proved to be capable of acquiring Hygromycin resistance by a mechanism that was unrelated to the presence of the antibiotic gene. This well described property of malignant cells (132) had allowed non-transfected clones to develop. Nevertheless in view of the efficacy of the promoter and the demonstrable presence of 17 -tPA-transfected clones, I am surprised that the clones carrying Hygromycin resistance in p17-tPAas did not have at least some advantage that would have enabled me to isolate them. This raises the interesting (and entirely speculative!) possibility that the translation of tPA message is essential for the survival of melanoma cells. If this were so, clones effectively transfected with p17-tPAas would have failed to synthesize IPA and they would have been eliminated from the proliferating population, leaving only Hygromycinresistant mutants to survive.

Experimental confirmation of this notion might come from experiments in which antisense tPA oligonucleotides were added to melanoma cell cultures and the effects on proliferation noted. If, indeed, tPA synthesis is required for melanoma cell proliferation one should observe inhibition. It is possible that IPA is directly required for cell growth. Perhaps a more likely explanation though, is that plasmin 
is required for the release/activation of growth factors such as bFGF (rev. 77), which are responsible for modulating cell proliferation.

As these melanoma cells approach confluence in culture so the rate at which they release tPA diminishes (fig. 2.12). This observation can be used, to some extent, to support the suggestion that a direct relationship exists between rate of proliferation and rate of tPA synthesis. This, however, was only true for any given clone. No correlation was observed when doubling times were plotted as a function of rate of $\mathrm{PPA}$ release.

Had I been successful in obtaining antisense transfectants producing reduced tPA, the problem of the clonal variation within the cell line would have made the results difficult to interpret, particularly with regard to the metastatic assay in the nude mouse. For example, I discovered that upon injection into nude mice, clone 11 did not even form a primary tumour (results not shown), thus any characteristic of a clone could not be attributed necessarily to the transfected phenotype. A solution to this problem would be to transfect the antisense gene under the control of an inducible promoter. Thus the uninduced clone could first be compared to the parental line and then only induced to produce antisense. This strategy would also allow antisense transfected, tPA dependent cells (as suggested above) to be cloned.

The evolution of metastatic cells in a primary tumour may be regarded as equivalent to in vivo cloning in the sense that it is probably only a small fraction of the population that has, or develops, the capacity to spread. This view casts doubt on the relevance of experimental approaches that study the whole 
population. One should, perhaps, examine several metastases for common features.

It is unfortunate that I was not able to demonstrate a specific tPA receptor on the UCT-Mel 3 cells, as this would have provided a mechanism of invasion in the absence of UPA. However tPA does appear to bind saturably to the cells (or possibly to the matrix attached to them) with an estimated $K_{d}$ in the range of $10^{-9}$ M. Using a similar approach, Bizik et al. (31) also showed binding of IPA to melanoma cells and found, interestingly, that the enzyme, when bound in this way, activated plasminogen efficiently in the presence of $\alpha_{2}$-macroglobulin. They suggested, without offering proof, that tPA might mediate invasion of melanoma cells in the manner suggested for UPA with other cell types. 


\section{APPENDIX}

\section{PART A: METHODS}

\section{A.1 Cell culture}

Cells were cultured in a Hotpack $\mathrm{CO}_{2}$ incubator at $37^{\circ} \mathrm{C}$ in a humid atmosphere containing $5 \% \mathrm{CO}_{2}$ in air. The culture medium used was RPMI 1640 supplemented with $10 \%$ heat inactivated $\left(56^{\circ} \mathrm{C} ; 30 \mathrm{~min}\right) \mathrm{FCS}, 50$ $\mathrm{U} / \mathrm{ml}$ penicillin and $20 \mu \mathrm{g} / \mathrm{ml}$ streptomycin sulfate. All solutions used in the culture of cells were sterilized by filtration through a $0.45 \mu \mathrm{m}$ Millipore filter. Cultures were passaged by incubating the cells briefly in $0.25 \%$ Trypsin, $0.02 \%$ EDTA in TD (B.). Cell stocks were maintained in liquid nitrogen and prepared by controlled freezing in RP10 containing 10\% DMSO. Cells were observed and photographed using a Nikon phase-contrast microscope with camera attachment.

\section{A.2 Mycoplasma staining}

All cell lines were tested for mycoplasma infection using Hoechst Stain no. 33258 at a concentration of $0.5 \mu \mathrm{g} / \mathrm{ml}$.

\section{A.3 Protease and inhibitor free (PIF) BSA}

Bovine serum albumin (Boehringer Mannheim) was dissolved in water to a concentration of $20 \mathrm{mg} / \mathrm{ml}$. Acid labile protease inhibitors were removed by adjusting the solution to $\mathrm{pH} 3.0$ with $0.1 \mathrm{M} \mathrm{HCl}$ and standing at room temperature for 2 hours. The solution was then neutralized with $0.1 \mathrm{M}$ $\mathrm{NaOH}$ and treated with diisopropylfluorphosphate (DFP) to inactivate serine proteases. The PIF BSA was stored in aliquots at $-20^{\circ} \mathrm{C}$. 


\section{A.4 DFP treatment}

DFP treatment was used to remove protease activity by adding DFP to 10 $\mathrm{mM}$ and incubating at $40^{\circ} \mathrm{C}$ for 2 hours. Unreacted DFP was removed by dialysing extensively against $0.1 \mathrm{M}$ Tris, $\mathrm{pH} 8.1$.

\section{A.5 BCA Protein determination}

Protein concentrations were determined using the Pierce Bicinchoninic acid reagent with BSA as a standard. The protocol was according to the directions supplied with the kit, however the amounts were scaled down for use in a 96 well microtiter plate.

\section{A.6 SDS Polyacrylamide Gel Electrophoresis}

$12 \%$ SDS polyacrylamide gels were prepared as follows:

Running gel ( $15 \mathrm{ml})$ :

$12 \%$ acrylamide/bis-acrylamide (29:1)

$1 \times$ SDS running gel buffer (B.18)

$10 \mu$ TEMED

$50 \mu 10 \%$ ammonium persulfate

Stacking gel $(5 \mathrm{ml})$ :

4\% acrylamide/bis-acrylamide (29:1)

$1 \times$ SDS stacking gel buffer (B.18)

$10 \mu$ TEMED

$50 \mu \mathrm{l} 10 \%$ ammonium persulfate

Samples were boiled for $5 \mathrm{~min}$ with a equal volume of $2 \times$ SDS sample buffer, loaded onto the gel and electrophoresed overnight at $80 \mathrm{~V}$. 


\section{A.7 Fibrin plate assay for plasminogen activator}

The assay relies on the measurement of plasminogen-dependent release of soluble, radioactive fibrin degradation peptides from an insoluble substrate of 125 -labelled fibrin adhering to the bottom surface of a plastic well.

1251 fibrin coated 24 well plates (Corning) were prepared as described by Strickland and Beers (1976). 125I-Fibrinogen and cold fibrinogen were added to the wells, such that each well contained 120000 to $130000 \mathrm{cpm}$ and $30 \mu \mathrm{g}$ fibrinogen. The plates were dried at $37^{\circ} \mathrm{C}$ for 3 days and thereafter stored at room temperature.

Before use the plates were incubated with $1 \mathrm{ml} \mathrm{RPMI}$ per well for 1 hour at $37^{\circ} \mathrm{C}$ and the wells washed twice with PBS pH 7.4 and once with $0.1 \mathrm{M}$ Tris.Cl, pH 8.1.

For the assay, each well contained $2 \mu \mathrm{g}$ of purified human plasminogen and $80 \mu \mathrm{g}$ of PIF BSA in a final volume of $300 \mu \mathrm{l}$ of $0.1 \mathrm{M}$ Tris.Cl pH 8.1. Samples to be tested were added in a maximum of $40 \mu$ l.

Control wells included:

1. $300 \mu$ trypsin (to give the total radioactivity present in each well.

2. no sample (to detect background lysis due to plasmin contamination of the plasminogen).

3. no sample, no plasminogen (to detect protease contamination of the other reagents)

3. sample, no plasminogen (to detect plasminogen independent protease activity). 
The standard wells contained 12 doubling dilutions of Urokinase diluted in the same medium as the samples.

The plates were incubated at $37^{\circ} \mathrm{C}$ in a humid atmosphere and $50 \mu \mathrm{l}$ aliquots were removed at 3 different timepoints and counted in a $\boldsymbol{\gamma}$-counter. For each timepoint a standard curve was plotted and sample values falling on the linear part of the curve were determined and expressed as units of urokinase per $\mathrm{ml}$.

\section{A.8 RNA Extraction}

RNA was extracted from cultured cells using the one-step guanidinium thiocyanate procedure ${ }^{\star}$. Approximately $2 \times 10^{7}$ cells were trypsinized and washed twice with $10 \mathrm{ml}$ PBS. Cell pellets were resuspended in $500 \mu \mathrm{l}$ each of Solution $\mathrm{D}$ ( $4 \mathrm{M}$ guanidinium thiocyanate, $25 \mathrm{mM}$ sodium citrate $\mathrm{pH}$ $7.0,0.5 \%$ sarkosyl, $0.1 \mathrm{M} \beta$-mercaptoethanol). The following were added sequentially, mixing well after each addition: $50 \mu l$ sodium acetate, $500 \mu \mathrm{l}$ water-saturated phenol and $100 \mu l$ chloroform:isoamyl alcohol (49:1). The solution was incubated on ice for $10 \mathrm{~min}$ and then microfuged for $15 \mathrm{~min}$. The aqueous phase was transferred to a fresh tube and the phenol extraction repeated. The aqueous phase was precipitated by addition of $500 \mu \mathrm{l}$ isopropanol and pelleted in a microfuge for $15 \mathrm{~min}$. Each pellet was resuspended in $150 \mu$ lof Solution D and then precipitated with an equal volume of isopropanol as before. RNA pellets were rinsed with $70 \%$ ethanol, air-dried and taken up in DEPC treated water (B.6). RNA concentration was determined spectrophotometrically, assuming that $1 \mathrm{OD}$ unit at $260 \mathrm{~nm}$ is equivalent to $40 \mu \mathrm{g}$ of RNA. $2 \times 10^{7}$ cells yielded approximately $200 \mu \mathrm{g}$ of total RNA. I obtained $260 \mathrm{~nm} / 280 \mathrm{~nm}$ ratios in 
excess of 1.8 .

* Initially I had tried an alternative method which involves phenol extraction of the cytoplasmic fraction, however I consistently failed to obtain intact RNA using this procedure. Presumably the success of the Guanidinium method is due to lysis of the cells in the presence of this strong denaturant, thus immediately inactivating RNAses, whilst the lysis of cells with detergent may allow RNAse activity before addition of phenol.

\section{A.9 Formaldehyde gels}

$1 \%$ agarose gels containing $2.2 \mathrm{M}$ formaldehyde were prepared as follows: $1.5 \mathrm{~g}$ of MP agarose (Boehringer Mannheim) was melted in $108 \mathrm{ml} \mathrm{DEPC}$ treated water and held in a $60^{\circ} \mathrm{C}$ water bath. $27 \mathrm{ml}$ of $12.3 \mathrm{M}$ deionized formaldehyde and $15 \mathrm{ml}$ 10x MOPS buffer were added and the mixture was poured into a slab mould. $20 \mu \mathrm{g}$ of RNA was prepared for loading in each lane as follows:

$9 \mu \mathrm{l}$ RNA $(20 \mu \mathrm{g})$

$20 \mu l$ deionized formamide

$7 \mu$ deionized formaldehyde

$4 \mu l 10 \times$ MOPS

Samples were heated at $55^{\circ} \mathrm{C}$ for $15 \mathrm{~min}$ and then $10 \mu \mathrm{l}$ RNA loading buffer was added. Gels were pre-electrophoresed in $1 \times$ MOPS for $10 \mathrm{~min}$. Samples were then loaded and run overnight at $20 \mathrm{~V}(1 \mathrm{~V} / \mathrm{cm}), 4^{\circ} \mathrm{C}$.

A.10 Northern hybridization analysis of RNA

Formaldehyde was removed from RNA gels by washing in DEPC water for one hour (with six changes). They were then equilibrated in 20x SSC and capillary blotted overnight onto Hybond $\mathrm{N}$ membrane (Amersham). Blots 
were dried, UV irradiated for two minutes and then stored at $4^{\circ} \mathrm{C}$. Blots were rehydrated in $6 \times$ SSC and sealed in a plastic bag containing $10 \mathrm{ml}$ RNA prehybridization fluid. After $2 \mathrm{hr}$ at $42^{\circ} \mathrm{C}$ in a shaking water bath, the prehybridization fluid was replaced and the freshly denatured, labelled probe was added at an activity of $10^{6} \mathrm{cpm} / \mathrm{ml}$. After hybridization overnight at $42^{\circ} \mathrm{C}$, blots were washed twice in $2 \times$ SSC, 0.1\% SDS for 15 $\mathrm{min}$ at room temperature and then twice in $0.1 \times$ SSC, 0.1\% SDS for $15 \mathrm{~min}$ at $42^{\circ} \mathrm{C}$. Damp blots were sealed in plastic and autoradiographed at $-80^{\circ} \mathrm{C}$ using preflashed Cronex $4 \mathrm{X}$-ray film and intensifying screens. Blots were stripped before reprobing by pouring boiling $0.1 \%$ SDS onto the blot and gently agitating until cold. Stripped blots were then prehybridized and hybridized as before.

\section{A.11. CDNA probe preparation}

Restriction enzyme digested plasmids were electrophoresed on $1 \mathrm{x}$ $\mathrm{TBE} / 1 \%$ low melting point agarose (Seaplaque) gels. The desired fragments were excised, weighed and diluted 1:3 with water. Approximately $50 \mathrm{ng}$ of the gel-purified fragment was random prime labelled (Boehringer Mannheim Random Prime Kit) using $50 \mu \mathrm{Ci}$ 32P-dCTP (Amersham). A $1 \mathrm{ml}$ Sephadex G-50 column was used to separate out unincorporated nucleotide. Fractions containing labelled DNA were pooled and an aliquot counted in a scintillation counter. Specific activities of at least $10^{8} \mathrm{cpm} / \mu \mathrm{g}$ were routinely obtained.

\section{A.12 Genomic DNA extraction}

Cultured cells were detached from dishes and washed once with PBS. The cells were centrifuged, resuspended in RSBT (B.10), incubated on ice for 
$15 \mathrm{~min}$ and then microfuged. The supernatant was removed and processed further for RNA extractions. The pellet containing nuclei was resuspended in $1 \%$ SDS, $1 \mathrm{mM}$ EDTA, $1 \times$ SSC and $100 \mu \mathrm{g} / \mathrm{ml}$ proteinase $\mathrm{K}$ and incubated overnight at $50^{\circ} \mathrm{C}$. Samples were phenol extracted and then precipitated by addition of 0.1 volumes $3 \mathrm{M}$ sodium acetate and 2 volumes ethanol and pelleted by centrifugation in a microfuge. DNA pellets were rinsed with $70 \%$ ethanol, air-dried and resuspended in water. Concentration was determined spectrophotometrically, assuming that 1 $O D$ unit at $280 \mathrm{~nm}$ is equivalent to $50 \mu \mathrm{g}$ of DNA.

\section{A.13 Southern Blot analysis of genomic DNA}

Genomic DNA was digested with EcoRI and Hindlil. $10 \mu \mathrm{g}$ of digested DNA per lane together with a $\lambda$-HindIII marker was electrophoresed on a $1 \%$ agarose/TBE gel at $20 \mathrm{~V}$ overnight $(1-2 \mathrm{~V} / \mathrm{cm})$. In order to facilitate sizing of bands later, gels were stained with $50 \mu \mathrm{g} / \mathrm{ml}$ of ethidium bromide and photographed. Gels were soaked in $0.2 \mathrm{M} \mathrm{HCl}$ for $10 \mathrm{~min}$, rinsed in water and then denatured with $0.5 \mathrm{M} \mathrm{NaOH}, 1.5 \mathrm{M} \mathrm{NaCl}$ for 90 min. After rinsing in water the gels were neutralized by soaking in $1.5 \mathrm{M} \mathrm{NaCl}, 1 \mathrm{M}$ Tris.Cl pH 7.4 for $30 \mathrm{~min}$. DNA was capillary blotted overnight onto Hybond N membrane (Amersham) using 20x SSC. Membranes were UV irradiated for $2 \mathrm{~min}$ and stored at $4^{\circ} \mathrm{C}$. Blots were rinsed in $6 \times \mathrm{SSC}$ and then prehybridized at $68^{\circ} \mathrm{C}$ for two hours. The prehybridization fluid was replaced with fresh solution containing denatured, labelled probe and hybridized with blots overnight at $68^{\circ} \mathrm{C}$. Blots were washed twice in $2 x$ SSC, $0.1 \%$ SDS for $15 \mathrm{~min}$ at room temperature and then twice in $0.1 \mathrm{x}$ SSC, $0.1 \%$ SDS for $15 \mathrm{~min}$ at $68^{\circ} \mathrm{C}$. Damp membranes were sealed in 
plastic and autoradiographed at $-80^{\circ} \mathrm{C}$ using preflashed Cronex X-ray film and intensifying screens.

\section{A.14 Casein zymography}

Casein indicator gels contained $2 \%$ skim milk, $1.25 \%$ low melting agarose, $0.04 \mathrm{M}$ Tris. $\mathrm{Cl}, \mathrm{pH} 8.1$ and $50 \mu \mathrm{g} / \mathrm{ml}$ human plasminogen. Immunochemical identification of PA type was achieved by adding inhibitory polyclonal antibodies to plasminogen activators $(0.5 \mathrm{mg} / \mathrm{ml})$. Plasminogen was omitted from the indicator gels in order to detect any plasminogen-independent lysis. Casein indicator gels were poured between glass plates with a backing of gelbond. SDS polyacrylamide gels containing fractionated PA samples were washed for $1 \mathrm{hr}$ in $2.5 \%$ Triton-X 100 to remove the SDS. The gels were then placed on the casein indicator gels and incubated in a humid environment at $37^{\circ} \mathrm{C}$ until bands of lysis were visible. Lytic bands were visualized on a dark ground light box and photographed.

\section{A.15 Antibody purification (94)}

$20 \mathrm{ml}$ of $0.06 \mathrm{M}$ acetate buffer ( $\mathrm{pH} \mathrm{4.8)}$ was added to $10 \mathrm{ml}$ of serum and the $\mathrm{pH}$ adjusted to 4.8 with $\mathrm{HCl}$. Caprylic acid (Sigma C-2875) $(0.76 \mathrm{ml})$ was added dropwise with stirring and the stirring was continued for a further $30 \mathrm{~min}$. The sample was centrifuged at $10000 \mathrm{~g}$ for $30 \mathrm{~min}$ and the supernatant containing the antibody was dialyzed against 50 volumes of PBS containing 2 mM EDTA. Immunoglobulins were precipitated by addition of an equal volume of saturated ammonium sulfate and stirring for $30 \mathrm{~min}$. The precipitate was pelleted by centrifugation, resuspended in 
PBS and dialyzed against 250 volumes of PBS. The antibody concentration was determined using the BCA reagents (Pierce).

\section{A.16 Soft agar cloning}

UCT-Mel 3 cells were removed from semi-confluent dishes using trypsin, resuspended well in RP10 and counted. All reagents and pipettes were held at $37^{\circ} \mathrm{C}$ prior to use. Feeder layers were prepared as follows: equal volumes of $1 \%$ molten agar (Sigma, cell culture tested) and 2x RPMI were mixed with 0.5 volumes of FCS and $2 \mathrm{ml}$ of the mixture pipetted into each $35 \mathrm{~mm}$ dish. The final FCS concentration was $20 \%$. Feeder layers were left to set at room temperature. Dilutions of cells were prepared at double the final concentration required and held at $37^{\circ} \mathrm{C}$. For the cell layer, equal volumes of $1.32 \%$ agar and $2 \times$ RPMI were mixed with 0.5 volumes of FCS, and $0.5 \mathrm{ml}$ of this was rapidly mixed with $0.5 \mathrm{ml}$ of diluted cells and plated onto the feeder layer. The final FCS concentration in the cell layer was $15 \%$.

Dishes were wrapped in saran wrap to prevent desiccation and incubated for approximately 14 days in a $37^{\circ} \mathrm{C}, 5 \% \mathrm{CO}_{2}$ incubator. Clones were picked under a dissecting microscope using a capillary tube attached to a mouth pipette. Individual clones were expelled into wells of a 96 well tissue culture plate containing $50 \mu$ of RP10, the plate wrapped in saran wrap and incubated as above. Clones were fed weekly, or when medium became yellow. When the wells became confluent, the cells were removed using versene and a plugged Pasteur pipette, centrifuged and plated in a 24 well plate. In a similar manner clones were transferred sequentially into $35 \mathrm{~mm}$ 
and then multiple $60 \mathrm{~mm}$ dishes and frozen in RP10/10\% DMSO at $-80^{\circ} \mathrm{C}$.

\section{A.17 Growth curves}

Cells were seeded in $35 \mathrm{~mm}$ tissue culture dishes (Corning) in $2 \mathrm{ml} \mathrm{RP10}$ at a density of $10^{5}$ cells per dish. At timepoints of $O$ (day after plating), 48, 120 and 168 hours, duplicate dishes were trypsinized and counted on a Coulter counter. Remaining dishes were fed with $2 \mathrm{ml} \mathrm{RP10}$. Doubling times were calculated from the slope of log cell number plotted against time.

\section{A.18 Conditioned medium}

Cells were seeded, in triplicate, in $60 \mathrm{~mm}$ tissue culture dishes (Corning) at densities of $1 \times 10^{5}, 2 \times 10^{5}$ and $10^{6}$. On the following day the medium was aspirated and the cell monolayer was washed twice with $5 \mathrm{ml}$ serum free RPMI $1640.2 \mathrm{ml}$ of serum free RPMI 1640 was then added and the cells incubated for 24 hours.

The conditioned medium was centrifuged at $1000 \mathrm{~g}$ for $5 \mathrm{~min}$ to pellet nonadherent cells and then collected into a polyethylene tube containing PIF BSA at a final concentration of $400 \mu \mathrm{g} / \mathrm{ml}$. Conditioned medium was stored frozen at $-20^{\circ} \mathrm{C}$. The adherent cells were trypsinized, pooled with the nonadherent cell pellet and counted in the coulter counter.

\section{A.19 lodogen tubes}

$1 \mathrm{mg}$ of lodogen (Pierce) was dissolved in $50 \mathrm{ml}$ chloroform and $1 \mathrm{ml}$ aliquots added to microfuge tubes. The chloroform was evaporated overnight at $4^{\circ} \mathrm{C}$ and the lodogen tubes stored at $-80^{\circ} \mathrm{C}$. 


\section{A.20 lodination}

Proteins were iodinated using the lodogen procedure. $10 \mu \mathrm{g}$ of protein was incubated with a total equimolar amount of $1251(50 \mu \mathrm{M})$ and Nal (50 $\mu \mathrm{M}$ ) in $50 \mu$ l of sodium phosphate buffer $\mathrm{pH}$ 7.4. Proportions of $125 \mathrm{l}$ and $\mathrm{Nal}$ were varied depending on specific activity required. The reaction was allowed to proceed for $10 \mathrm{~min}$ at room temperature and then terminated by removal from the lodogen tube. The reaction was left at room temperature for a further $15 \mathrm{~min}$ and then applied to a $1 \mathrm{ml}$ Sephadex G-50 column equilibrated with $0.05 \mathrm{M}$ phosphate buffer containing $0.1 \%$ Triton $\mathrm{X}-100$. Fractions $(100 \mu l)$ were collected and counted in a gamma counter. Trichloroacetic acid (TCA) precipitable counts were determined by diluting $1 \mu \mathrm{l}$ of each fraction in $500 \mu \mathrm{l}$ PBS/0.1\% BSA and adding $50 \mu \mathrm{l}$ of $100 \%$ TCA. After incubating on ice for $15 \mathrm{~min}$ the precipitate was microfuged for $5 \mathrm{~min}$. The \% precipitable counts were (cpm in pellet/total cpm) $\times 100$.

\section{A.21 Karyotyping}

A semiconfluent $60 \mathrm{~mm}$ dish of cells was harvested, resuspended in $5 \mathrm{ml}$ of RPMl containing $0.2 \mu \mathrm{g} / \mathrm{ml}$ colcemid (Gibco) and incubated for $45 \mathrm{~min}$ in a $37{ }^{\circ} \mathrm{C}, 5 \% \mathrm{CO}_{2}$ incubator. Cells were then harvested and subjected to hypotonic treatment as follows: The aspirated cell pellet was tapped gently to resuspend cells, two drops of $0.56 \% \mathrm{KCl}$ added, followed by $2 \mathrm{ml}$. Cells were gently resuspended and allowed to stand at room temperature for 20 $\mathrm{min}$. Cells were then centrifuged at $1500 \mathrm{rpm}$ for $5 \mathrm{~min}$ and the supernatant removed. The cell pellet was tapped gently and $2 \mathrm{ml}$ fixative (methanol:acetic acid, 3:1) added. Cells were pelleted and resuspended in fixative as before, and allowed to stand for $20 \mathrm{~min}$ before pelleting again. All but $0.5 \mathrm{ml}$ of the fixative was removed, and the pellet resuspended. 
Cells were dropped from a height of $30 \mathrm{~cm}$ onto clean, cooled slides. Slides were flamed dry and stained with Giemsa stain for $10 \mathrm{~min}$ followed by washing in water. Slides were viewed under $100 \times$ magnification.

\section{A.22 Plasmid purification}

Alkaline lysis (136):

A $200 \mathrm{ml}$ culture of bacteria carrying plasmid was grown up overnight in TB containing $100 \mu \mathrm{g} / \mathrm{ml}$ of ampicillin. The bacteria were harvested by centrifugation at $8000 \mathrm{rpm}$ in a Beckman JA-10 rotor. The pellet was resuspended in $18 \mathrm{ml}$ of solution I (B.15), followed by addition of $2 \mathrm{ml}$ freshly prepared $2 \mathrm{mg} / \mathrm{ml}$ lysozyme. $40 \mathrm{ml}$ of freshly prepared solution II (B.16) was added, mixed by inversion and left to stand for $5 \mathrm{~min}$. Ice-cold solution III (B.17) ( $20 \mathrm{ml}$ ) was added and mixed thoroughly by shaking the centrifuge bottle. The solution containing a flocculant white precipitate was left on ice for $10 \mathrm{~min}$. The precipitate was pelleted by centrifugation at 10 $000 \mathrm{rpm}$ and the supernatant filtered through a syringe containing glass wool, in order to remove remaining precipitate. Plasmid was precipitated by addition of 0.6 volumes of isopropanol. The pellet was rinsed with $70 \%$ ethanol, air-dried and then resuspended in $3 \mathrm{ml}$ of TE.

\section{$\mathrm{CsCl}$ purification}

The pellet obtained after alkaline lysis was made up to $4 \mathrm{ml}$ with TE, $4 \mathrm{~g}$ of $\mathrm{CsCl}$ added followed by $0.4 \mathrm{ml}$ of $10 \mathrm{mg} / \mathrm{ml}$ ethidium bromide. The solution was transferred to a $5 \mathrm{ml}$ Beckman Quikseal tube which was balanced and then sealed. Tubes were centrifuged in a Beckman L8-80 ultracentrifuge for 18 hours at $50000 \mathrm{rpm}, 20{ }^{\circ} \mathrm{C}$. The fluorescent plasmid band was removed through the side of the tube using a syringe and 
needle. Ethidium bromide was removed by repeated extraction with isoamyl alcohol, until the aqueous phase was no longer pink. The solution was diluted threefold with water and then ethanol precipitated. The pellet was rinsed with $70 \%$ ethanol, air dried and resuspended in TE. Plasmid DNA concentration was determined spectrophotometrically. * $\mathrm{CsCl}$ purification was used only when very pure plasmid DNA was required, as in the case of transfections.

\section{A.23 Boiling minipreps}

$1.5 \mathrm{ml}$ of an overnight culture was pelleted by microcentrifugation for 20 sec. The supernatant was discarded and the bacterial pellet thoroughly resuspended in $300 \mu$ l of STET buffer (B.14) containing $200 \mu \mathrm{g}$ lysozyme. Tubes were then held on ice for $5 \mathrm{~min}$ before placing in a boiling water bath for $1 \mathrm{~min}$. The combination of heating and detergent causes lysis of cell walls and release of bacterial RNA and plasmid DNA. Microcentrifugation for 15 min pellets debris and chromosomal DNA, producing a loose gummy pellet. The supernatant, containing plasmid DNA was removed and precipitated by addition of an equal volume of isopropanol. After centrifugation the supernatant was removed, the pellet rinsed with $70 \%$ ethanol and air dried. Plasmid DNA was resupended in $50 \mu$ of TE. RNAse at $40 \mu \mathrm{g} / \mathrm{ml}$ was added to restriction enzyme digests.

\section{A.24 Establishment of UCT-Mel 3 (100)}

History: Tumor tissue was obtained from a 71 year old Caucasian female (DH). A pigmented lesion was removed from the medial aspect of the left calf of this patient in January 1976 and was found to be a malignant melanoma. Recurrence in the periphery of the scar occurred 8 months 
later. In April 1977, a liver scan indicated possible metastasis and in March 1978 a large melanomatous deposit was removed from the left lobe, from which the cell line in tissue culture was established. Malignant infiltration subsequently occurred in the sternum, lungs, spine and brain and the patient died in December, 1978.

The liver metastasis obtained for tissue culture was very soft and fragile with large pale nodules of tumor visible in the reddish black liver tissue. The tumour tissue disintegrated readily upon mincing with scissors and large numbers of viable cells were obtained from the trypsin digested tissue. The initial culture dishes were passaged after $48 \mathrm{hr}$. After five weekly passages normal fibroblasts contamination of the culture had increased markedly and fibroblasts threatened to overgrow the tumor cells. This line, however, shed large numbers of viable cells into the medium and these were collected from a number of dishes, centrifuged, and reseeded on a separate dish. In this manner a relatively pure culture of melanoma cells was obtained. This procedure was repeated twice before a pure culture of melanoma cells was established. The cells removed from the supernatant adhered readily when plated on a new petri dish.

The UCT-Mel 3 cell line grew as an adherent monolayer of triangular dendritic cells. At confluence the cells piled up, forming large multilayered clumps and therefore failed to display contact inhibition. Giant multinucleated cells were frequently seen. The cells were nonpigmented at both high and low densities. 


\section{A.25 CAT assay}

Cells were washed once in PBS and then in TEN (B.) buffer and transferred to a $1.5 \mathrm{ml}$ microfuge tube. The cell pellet was resuspended in $60 \mu \mathrm{l}$ of 0.25 M Tris, $\mathrm{pH} 8.0$ and cells disrupted by three freeze/thaw cycles. Cell debris was pelleted in a microfuge and the supernatant stored at $-80^{\circ} \mathrm{C}$. The standard reaction mix was as follows:

$5 \mu$ Acetyl CoA

$5 \mu l$ C14-Chloramphenicol

$x \mu l$ sample/standard dilution of CAT (125-x) $\mu \mathrm{l} 0.1 \mathrm{M}$ TrisCl, pH 8.0

Commercial CAT enzyme was diluted in $0.1 \mathrm{M}$ Tris, $\mathrm{pH} 8.0$ to $0.1,0.05$, $0.025,0.01$ and 0.005 units for the standard curve. Negative controls were cell lysates from untransfected cells. Samples were incubated at $37^{\circ} \mathrm{C}$ for 0.5-20 hr. Cell debris was pelleted and the supernatant extracted with 300 $\mu l$ of xylene. The upper xylene phase was transferred to a fresh tube and back extracted with $100 \mu$ l of Tris buffer. The extraction was repeated for maximum sensitivity. $200 \mu$ of the xylene was transferred to a scintillation vial containing Instagel and counted in a $\beta$-counter. Values obtained for cell lysates were calculated from the standard curve.

\section{A.26 PCR}

PCR reaction mix $(50 \mu$ total):

$1 \times$ PCR buffer

$200 \mu \mathrm{M}$ dNTP's

$0.2 \mu \mathrm{M}$ primers

$2.0 \mathrm{mM} \mathrm{MgCl} 2$ 


\section{$1.25 \cup$ Taq polymerase}

Reaction mix was overlaid with mineral oil

\section{A.27 Cell lysates for PCR}

Cultured cells were resuspended at a concentration of $10^{\circ}$ cells $/ \mathrm{ml}$ in PCR lysis buffer. Samples were then incubated at $56^{\circ} \mathrm{C}$ for $1-2 \mathrm{hr}$ and then heated to $95^{\circ} \mathrm{C}$ for $10 \mathrm{~min}$. Cell lysates were stored at $-80^{\circ} \mathrm{C}$ and $1-2 \mu \mathrm{l}$ used as template in a $50 \mu \mathrm{PCR}$ reaction.

\section{A.28 Ligations}

Ligations were performed using $100 \mathrm{ng}$ of vector DNA and a 2:1 molar ratio of insert to vector. The reaction volume was $10 \mu$, containing $1 \mathrm{u}$ of ligase (Boehringer Mannheim) and the buffer supplied by the manufacturer. The ligation proceeded overnight in a $16^{\circ} \mathrm{C}$ waterbath.

\section{A.29 Transformation}

Competent DH5 E.Coli cells were prepared using the calcium chloride method. $20 \mu$ of competent cells were incubated with the following for 20 $\min$ on ice:

1. $1 \mathrm{ng}$ of intact vector (to assess transformation efficiency of competent cells)

2. $5 \mu$ l of the ligation reaction.

3. $50 \mathrm{ng}$ of digested vector (to assess efficiency of digestion).

4. $50 \mathrm{ng}$ of digested and CIPed vector (to assess efficiency of CIP).

5. $5 \mu l$ water (negative control).

The transformations were heat shocked for $90 \mathrm{sec}$ at $42^{\circ} \mathrm{C}$ after which 800 $\mu l$ of LB was added and the tubes shaken for 1 hour at $37^{\circ} \mathrm{C}$ in order to 
allow expression of ampicillin resistance. Various dilutions of the transformations were plated on LB agar containing $100 \mu \mathrm{g} / \mathrm{ml}$ Ampicillin and incubated overnight at $37^{\circ} \mathrm{C}$.

The completed digest was incubated with $5 \mathrm{u}$ of CIP for $60 \mathrm{~min}$ at $37^{\circ} \mathrm{C}$. The CIP was heat inactivated at $75^{\circ} \mathrm{C}$ for $15 \mathrm{~min}$ and removed by phenol/chloroform extraction. The DNA was ethanol precipitated

\section{A.30 Chromogenic assay}

A microtiter plate was coated overnight at $4^{\circ} \mathrm{C}$ with polyclonal $\alpha$-tPA (\#123) diluted to $20 \mu \mathrm{g} / \mathrm{ml}$ in PBS. The plate was then blocked with $200 \mu \mathrm{l} /$ well of $5 \%$ skim milk powder dissolved in PBS, for $1 \mathrm{hr}$ at room temperature. After rinsing twice with PBS, $50 \mu$ of either standard samples (diluted in RPMI containing $0.1 \%$ Tween 20 ) or conditioned medium was added for $1 \mathrm{hr}$. Unbound antigen was removed by washing $7 x$ with TST. The detection solution contained $20 \mu \mathrm{g} / \mathrm{ml}$ plasminogen and $5 \mathrm{mM}$ PL-substrate (Spectrozyme) in $0.1 \mathrm{M}$ Tris $(\mathrm{pH} \mathrm{7.4)/0.1 \%} \mathrm{Tween} \mathrm{20.} 100 \mu \mathrm{l} /$ well of detection solution was added and the plate was incubated, with shaking at $37^{\circ} \mathrm{C}$. The optical density was read at $405 \mathrm{~nm}$ at different timepoints $(60$, 90 and $120 \mathrm{~min}$ ).

\section{A.31 Transcription}

DNA templates were linearized, gel-purified and phenol extracted before use. Transcription reaction mixes (20 $\mu l)$ were prepared as follows (using the Promega kit):

$4 \mu \mathrm{l} 10 \mathrm{x}$ transcription buffer

$2 \mu 100 \mathrm{mM}$ DTT

$1 \mu \mathrm{l}$ RNAsin $(50 \mathrm{u})$ 
$4 \mu \mathrm{I}$ NTP's $(0.5 \mathrm{mM})$

$2 \mu \mathrm{l}$ H H-UTP $(24 \mu \mathrm{M})$

$1 \mu \mathrm{l}$ template $( \pm 1 \mu \mathrm{g})$

$1 \mu \mathrm{l}$ SP6/T7 RNA polymerase

Transcription was at $37^{\circ} \mathrm{C}(\mathrm{T7})$ or $40^{\circ} \mathrm{C}(\mathrm{SP} 6)$ for $1 \mathrm{hr}$. Samples were then phenol extracted, precipitated with ethanol and electrophoresed on a $4 \%$ denaturing polyacrylamide gel.

\section{A.32 Acid treatment of cells}

Receptors were stripped of ligand before performing all binding experiments. The cells were detached with versene, washed once in binding medium (HEPES buffered RPMI containing $0.5 \% \mathrm{BSA}$ ) and then resuspended in $2 \mathrm{ml}$ of $50 \mathrm{mM}$ glycine ( $\mathrm{pH} 3), 0.1 \mathrm{M} \mathrm{NaCl}$ for $3 \mathrm{~min}$ at RT. The acid was neutralized by addition of $0.5 \mathrm{ml}$ of $0.5 \mathrm{M} \mathrm{HEPES}(\mathrm{pH} \mathrm{7.7)}$, $0.1 \mathrm{M} \mathrm{NaCl}$. Binding buffer was then added to a volume of $10 \mathrm{ml}$ and the cells were pelleted by centrifugation.

\section{PART B: SOLUTIONS}

\section{B. 1 PBS}

$137 \mathrm{mM} \mathrm{NaCl}$

$2.7 \mathrm{mM} \mathrm{KCl}$

$4.3 \mathrm{mM} \mathrm{Na}_{2} \mathrm{HPO}_{4}$

$1.4 \mathrm{mM} \mathrm{KH}_{2} \mathrm{PO}_{4}$

B.2 MOPS

0.1 M MOPS (3-( $\mathrm{N}$-morpholino)propanesulfonic acid) 
$40 \mathrm{mM}$ sodium acetate

5 mM EDTA (pH 8.0)

B.3 10XTBE

$89 \mathrm{mM}$ Tris base

$89 \mathrm{mM}$ boric acid

2 mM EDTA, pH 8.0

B.4 Solution D

$4 \mathrm{M}$ guanidinium thiocyanate

$25 \mathrm{mM}$ sodium citrate $\mathrm{pH} 7$

$0.5 \%$ sarkosyl

$0.1 \mathrm{M} \beta$-mercaptoethanol

B.5 Deionised formamide/formaldehyde

Deionised formamide/formaldehyde was prepared by tumbling overnight with $1 \%(w / v)$ mixed bed resin (Biorad AG-501 X8), followed by filtration through Whatman No.1.

B.6 DEPC treatment

DEPC was added to solutions at $0.1 \%$, incubated overnight $\left(37^{\circ} \mathrm{C}\right)$, then autoclaved to remove remaining DEPC.

B.7 20x SSC

$3 \mathrm{M} \mathrm{NaCl}$

$0.3 \mathrm{M} \mathrm{Na}_{3}$ citrate, $\mathrm{pH} 7.0$

B.8 RNA hybridization solution

6x SSC

$50 \%$ deionised formamide

5x Denhardts solution

$0.5 \%$ SDS

$100 \mu \mathrm{g} / \mathrm{ml}$ salmon sperm DNA (freshly denatured) 
B.9 DNA hybridization solution

$6 \times$ SSC

$5 \times$ Denhardts solution

$0.5 \%$ SDS

$100 \mu \mathrm{g} / \mathrm{ml}$ salmon sperm DNA (freshly denatured)

B.10 RSBT

$10 \mathrm{mM}$ Tris. $\mathrm{Cl}(\mathrm{pH} 7.5)$

$10 \mathrm{mM} \mathrm{NaCl}$

$1.5 \mathrm{mM} \mathrm{MgCl} 2$

$2 \%$ Triton $X-100$

B.11 RNA loading buffer

$50 \%$ glycerol

1 mM EDTA (pH 8.0)

$0.25 \%$ bromophenol blue

$0.25 \%$ xylene cyanol FF

B.12 LB medium

$10 \mathrm{~g}$ bacto-tryptone

$5 \mathrm{~g}$ bacto-yeast extract

$10 \mathrm{~g} \mathrm{NaCl}$

B.13 TE

$10 \mathrm{mM}$ Tris. $\mathrm{Cl}(\mathrm{pH} 8.0)$

1 mM EDTA

\section{B.14 STET}

\section{$0.1 \mathrm{M} \mathrm{NaCl}$}

$10 \mathrm{mM}$ Tris. $\mathrm{Cl}(\mathrm{pH} \mathrm{8.0)}$

1 mM EDTA

5\% Triton-X 100 


\section{B.15 Solution I}

$50 \mathrm{mM}$ glucose

$25 \mathrm{mM}$ Tris.Cl (pH 8.0)

10 mM EDTA

B.16 Solution II (freshly prepared)

$0.2 \mathrm{~N} \mathrm{NaOH}$

$1 \%$ SDS

B.17 Solution III

$60 \mathrm{ml}$ of $5 \mathrm{M}$ potassium acetate

$11.5 \mathrm{ml}$ glacial acetic acid

$28.5 \mathrm{ml} \mathrm{H}_{2} \mathrm{O}$

B.18 SDS PAGE Buffers

$4 \times$ running gel buffer:

$1.5 \mathrm{M}$ Tris. $\mathrm{Cl}$ ( $\mathrm{pH} 8.8), 0.4 \%$ SDS

4x stacking gel buffer:

$0.5 \mathrm{M}$ Tris. $\mathrm{Cl}$ (pH 6.8), 0.4\% SDS

$5 x$ electrophoresis buffer:

$0.125 \mathrm{M}$ Tris. $\mathrm{Cl}$ (pH 8.5)

0.96 M Glycine

$0.5 \%$ SDS

$2 \times$ SDS sample buffer:

1x stacking buffer, $20 \%$ glycerol, 4\% SDS, 0.001\% Bromophenol blue.

B.19 PCR lysis buffer

$50 \mathrm{mM} \mathrm{KCl}$

$10 \mathrm{mM}$ Tris.Cl (pH 8.3)

$2.5 \mathrm{mM} \mathrm{MgCl}_{2}$

$0.5 \%$ Nonidet P-40 


\author{
$0.5 \%$ Triton- $X 100$ \\ $120 \mu \mathrm{g} / \mathrm{ml}$ proteinase $\mathrm{K}$ \\ B.20 (5x) Versene \\ $3.5 \mathrm{mM} \mathrm{Na} 2 \mathrm{EDTA}$ \\ $13.4 \mathrm{mM} \mathrm{KCl}$ \\ $0.685 \mathrm{M} \mathrm{Na}_{2} \mathrm{HPO}_{4} .2 \mathrm{H}_{2} \mathrm{O}$ \\ $7.4 \mathrm{mM} \mathrm{KH}_{2} \mathrm{PO}_{4}$ \\ B.21 TEN \\ $50 \mathrm{mM}$ Tris. $\mathrm{Cl}(\mathrm{pH} 7.5)$ \\ $100 \mathrm{mM} \mathrm{NaCl}$ \\ 5 mM EDTA \\ B.22 (100x) Denhardts solution \\ $2 \%$ Ficoll 400 \\ $2 \%$ polyvinylpyrrolidine \\ $2 \%$ BSA \\ B.23 (2x) trypsin diluent (TD) \\ $0.27 \mathrm{M} \mathrm{NaCl}$ \\ $0.01 \mathrm{M} \mathrm{KCl}$ \\ $1.4 \mathrm{mM} \mathrm{Na}_{2} \mathrm{HPO}_{4}$ \\ $0.05 \mathrm{M}$ Tris (pH 7.4)
}




\section{BIBLIOGRAPHY}

1. Poste, G., Fidler, I.J (1980). The pathogenesis of cancer metastasis. Nature 283: 139-146.

2. Schirrmacher, V. (1985). Cancer metastasis: experimental approaches, theoretical concepts and impact for treatment strategies. Adv. Cancer Res. 43: 1-173.

3. Weiss, L. (1980). Cancer cell traffic from the lung to the liver: An example of metastatic inefficiency. Int. J. Cancer 25: 385-392.

4. Gorelik, E. (1992). Protective effect of fibrin on tumor metastases. Fibrinolysis 1: 35-38.

5. Paget, S. (1889). The distribution of secondary growths in cancer of the breast. Lancet 1: 571-573.

6. Ewing, J. (1928). A treatise on tumors. 3rd ed. Philadelphia: W.B. Saunders.

7. Dano, K., Andreasen, P.A., Grondhal-Hansen, J., Kristensen, P., Nielsen, L.S., Skriver, L. (1985). Plasminogen activators, tissue degradation and cancer. Adv. Cancer Res. 44: 140-239.

8. Mullins, T.E., Rohrlich, S.T. (1983). The role of proteinases in cellular invasiveness. Biochim. Biophys. Acta 695: 177-214. 
9. Humphries, M.J., Olden, K., Yamada, K.M. (1986). A synthetic peptide from fibronectin inhibits experimental metastasis of murine melanoma cells. Science 233: 467-470.

10. Humphries, M.J., Yamada, K.M., Olden, K. (1988). Investigation of the biological effects of anti-cell adhesive synthetic peptides that inhibit experimental metastasis of B16-F10 murine melanoma cells. J. Clin. Invest. 81: 782-790.

11. Zetter, B.R. (1990). The cellular basis of site-specific tumor metastasis. New Engl. J. Med. 322: 605-612.

12. Auerbach, R., Lu, W.C., Pardon, E., Gumkowski, F., Kaminska, G., Kaminska, M. (1987). Specificity of adhesion between murine tumour cells and capillary endothelium: an in vitro correlate of preferential metastasis in vivo. Cancer Res. 47: 1492-1496.

13. Doerr, R., Zvibel, I., Chiuten, D., D'Olimpio, J., Reid, L.M. (1989). Clonal growth of tumour on tissue-specific biomatrices and correlation with organ site specificity of metastases. Cancer Res. 49: 384-392.

14. Rice, G.E., Gimbrone, M.A. Jr., Bevilacqua,M.P. (1988). Tumor cellendothelial interactions: increased adhesion of human melanoma cells to activated vascular endothelium. Am. J. Pathol. 133: 204-210. 
15. Pauli, B.U., Lee, C.L. (1988). Organ preference of metastasis: the role of organ specifically modulated endothelial cells. Lab. Invest. 58: 379-387.

16. Varani, J. (1982). Chemotaxis of metastatic tumor cells. Cancer Metastasis Rev. 1: 17-28.

17. McCarthy, J.B., Basara, M.L., Palm, S.L., Sas, D.F., Furcht, L.T. (1985). The role of cell adhesion proteins - laminin and fibronectin - in the movement of malignant and metastatic cells. Cancer Metastasis Rev. 4: 125-152.

18. Juliano, R.L. (1987). Membrane receptors for extracellular matrix macromolecules: relationship to cell adhesion and tumour metastasis. Biochim. Biophys. Acta 907: 261-278.

19. Humphries, M.J., Obaro, M., Olden, K., Yamada,K.M. (1989). Role of fibronectin in adhesion, migration and metastasis. Cancer Invest. 7(4): 373-393.

20. Emonard, H., Grimaud, J. (1990). Matrix metalloproteinases. A review. Cell. Mol. Biol. 36: 131-153.

21. Bachmann, F. (1987). Fibrinolysis. In: Verstraete,M.m Vermylen, J., Lijnen, R., Arnout, J. (eds). Thrombosis and haemostasis. Belgium University press, Lewen. 227-266. 
22. Tryggvasonn, K., Hoyhtya, M., Salo, T. (1987). Proteolytic degradation of extracellular matrix in tumor invasion. Biochim. Biophys. Acta 907: 191217.

23. Bachmann, F., Kruithof, E.K.O. (1984). Tissue plasminogen activator: Chemical and physiological aspects. Semin. Thromb. Hemost. 10: 6-17.

24. Rajput, A., Degen, S.F., Reich, E., Waller, E.K., Axelrod, J., Eddy, R.L., Shows, T.B. (1988). Chromosomal locations of human tissue plasminogen activator and urokinase genes. Science 230: 672-674.

25. Ny, T., Elgh, F., Lund, B. (1984). The structure of the human tissue-type plasminogen activator gene: correlation of intron and exon structures to functional and structural domains. Proc. Natl. Acad. Sci. USA 81: 53555359.

26. Blasi, F., Riccio, A., Sebasti, G. (1986). Human plasminogen activators. Genes and protein structures. In: Blasi (ed) Human Genes and diseases. John Wiley \& Sons, New York, pp 377-392.

27. Hajjar,K.A., Hamel, N.M., Harpel, P.C., Nachman, R.L. (1987). Binding of tissue plasminogen activator to cultured human endothelial cells. J. Clin. Invest. 80: 1712-1719.

28. Sanzo, M.A., Howard, S.C., Wittwer, A.J., Cochrane, H.M. (1990). Binding of tissue plasminogen activator to human aortic endothelial cells.

Biochem. J. 269: 475-482. 
29. Owensby, D.A., Sobel, B.E., Shwartz, A.L. (1988). Receptor-mediated endocytosis of tissue-type plasminogen activator by the human hepatoma cell line Hep G2. J. Biol. Chem. 263: 10587-10594.

30. Nguyen, G., Self, S.J., Camani, C., Kruithof, E.K.O. (1992). Demonstration of a specific clearance receptor for tissue-type plasminogen activator on rat Novikoff hepatoma cells. J. Biol. Chem. 267: 6249-6256.

31. Bizik, J., Lizonova, A., Stephens, R.W., Grofova, M., Vaheri, A. (1990). Plasminogen activation by $t-P A$ on the surface of human melanoma cells in the prescence of $\alpha$-macroglobulin secretion. Cell Regul. 1: 895-905.

32. Hajjar, K.A. (1991). The endothelial cell tissue plasminogen activator receptor. J. Biol. Chem. 266: 21962-21970.

33. Hajjar, K.A., Harpel, P.C., Jaffe, E.A., Nachman, R.L. (1986). Binding of plasminogen to cultured human endothelial cells. J. Biol. Chem. 263(25): 11656-11662

34. Barnathan, E.S., Kuo, A., Van der Keyl, H., McRae, K.R., Larsen, G.R., Cines, D.B. (1988). Tissue-type plasminogen activator binding to human endothelial cells. J. Biol. Chem. 263(16): 7792-7799.

35. Testa, J.E., Quigley, J.P. (1990). The role of urokinase-type plasminogen activator in aggressive tumour cell behaviour. Cancer Metastasis Rev. 9: 355-367. 
36. Hoal-Van Helden, E.G., Wilson, E.L., Dowdle, E.B. (1986).

Characterisation of seven human melanoma cell lines: Melanogenesis and secretion of plasminogen activators. Br. J. Cancer 54: 287-295.

37. Rijken, D.C., Collen, D. (1981). Purification and characterisation of the plasminogen activator secreted by human melanoma cells in culture. J. Biol. Chem. 256: 7035-7042.

38. Wagner, O.F., binder, B.R. (1986). Purification of an active inhibitor immunologically related to the endothelial type plasminogen activator inhibitor from the media of a human melanoma cell line. J. Biol. Chem. 261: 14474-14481.

39. White W.F., Barrow, G.H., Mozen, M.M. (1955). The isolation and characterisation of plasminogen activators (urokinase) from human urine. Biochemistry 5: 2160-2169.

40. Sobel, G.W., Mohler, S.R., Jones, H.W., Mieller, K.R., Peluso, R. (1952). Urokinase: an activator of plasma profibrinolysin extracted from urine. Am. J. Physiol 171: 768-769.

41. Peterson, L.C., Lund, L.R., Nielsen, L.S., Dano, K., Skrivier, L. (1988). One chain urokinase-type plasminogen activator from human sarcoma cells is a proenzyme with little or no intrinsic activity. J. Biol. Chem. 263: 1118911195. 
42. Gunzler, W.A., Steffens, G.J., Otting, F., Kim, S.M., Frankus, E., Floke, L. (1982). The primary structure of high molecular mass urokinase from human urine. The complete amino acid sequence of the A-chain. Hoppe Seylers Z. Physiol. Chem. 363: 1155-1165.

43. Husain, S.S., Gurewich, V., Lipinski, B. (1983). Purification and partial form characterisation of a single-chain, high molecular weight of urokinase from urine. Arch. Biochem. Biophys. 220: 31-38.

44. Ichinose, A., Fujikawa, K., Suyama, T. (1983 1986). The activation of prourokinase by plasma kallikrein and its inactivation by thrombin. J. Biol. Chem. 261: 3486-3489.

45. Appella, E., Robinson, E.A., Ullrich, S.J., Stopelli, M.P., Corti, A., Cassani, G., Blasi, F. (1987). The receptor binding sequence of urokinase. A biological function of the growth factor module. J. Biol. Chem. 262:44374440.

46. Faribairn, S., Gilbert, R., Ojakian, G., Schwimmer, R., Quigley, J.P. (1985). The extracellular matrix of normal chick embryo fibroblasts: its effect on transformed chick fibroblasts and its proteolytic degradation by the transformation. J. Cell Biol. 101: 1790-1798.

47. Rabbani, S.A., Desjardins, J., Bell, A.W., Banville, E., Golzman, D. (1990). An amino-terminal fragment of urokinase isolated from a prostrate cancer cell line (PC-3) is mitogenic for osteoblast-like cells. Biochem. Biophys. Res. Commun. 173: 1058-1064. 
48. Kircheimer, J.C., Wojta, J., Christ, G., Binder, B.R. (1987). Functional inhibition of endogenously produced urokinase decreases cell proliferation in a human melanoma cell line. Proc. Natl. Acad. Sci. USA 86: 5424-5428.

49. Gudewicz, P.W., Gilboa, H. (1987). Human urokinase-type plasminogen activator stimulates chemotaxis of human neutrophils. Biochem. Biophys. Res. Commun. 147: 1176-1181.

50. Min, H.Y., Semnani, R., Mizukami, I.F., Watt, K., Todd, R.F., Liu, D.Y. (1992). cDNA for Mo3, a monocyte activation antigen, encodes the human receptor for urokinase plasminogen activator. J. Immunol. 148: 36363642 .

51. Kircheimer, J.C. (1987). Proliferation of a human epidermal tumor cell line stimulated by urokinase. FASEB J. 1: 125-128.

52. Kircheimer, J.C., Christ, G., Binder, B.R. (1989). Growth stimulation of human epidermal cells by urokinase is restricted to the intact enzyme. Eur. J. Biochem. 181: 103-107.

53. Stefanova, I., Horejsi, V., Ansotegui, I.J., Knapp, W., Stockinger, H. (1991). GPI-anchored cell-surface molecules complexed to protein tyrosine kinases. Science, 254: 1016-1019. 
54. Dumler, I., Petri, T.,Schleuning, W.D. (1993). Interaction of urokinase-type plasminogen activator (U-PA) with its cellular receptor (U-PAR) induces phosphorylation on tyrosine of a 38kDa protein. FEBS Lett. 322: 37-40.

55. Nielsen, L.S., Kellerman, G.M., Behrendt, N., Picone, R., Dano, K.,Blasi, F. (1988). A 55,000-60,000 $M_{r}$ receptor protein for urokinase-type plasminogen activator. J. Biol. Chem. 263: 2358-2363.

56. Roldan, A.L., Cubellis, M.V., Masucci, M.T., Behrendt, N., Lund, L.R., Dano, K., Appella, E., Blasi, F. (1990). Cloning and expression of the receptor for human urokinase plasminogen activator, a central molecule in cell surface, plasmin dependant proteolysis. EMBO J. 9: 467-474.

57. Estreicher, A., Wohlwend, A., Belin, D., Schleuning, W.D., Vassalli, J.D. (1989). Characterisation of the cellular binding site for the urokinase-type plasminogen activator. J. Biol. Chem. 254: 1180-1189.

58. Vassalli, J.D., Baccino, D., Belin, D. (1985). A cellular binding site for the Mr 55,000 form of the human plasminogen activator, urokinase. J. Cell Biol. 100: 86-92.

59. Blasi, F., Stopelli, M.P., Cubellis, M.V. (1986). The receptor for urokinaseplasminogen activator. J. Cell. Biochem. 32: 179-186.

60. Ploug, M., Ronne, E., Behrent, L.N., Jensen, A.L., Blasi, F., Dano, K. (1991). Cellular receptor for urokinase plasminogen activator. J. Biol. Chem. 266: 1926-1933. 
61. Behrendt, N., Ronne, E., Ploug, M., Petri, T., Lober, D., Nielsen, L.S., Schleuning, W.D., Blasi, F., Appella, E., Dano, K. (1990). The human receptor for urokinase plasminogen activator. J. Biol. Chem. 265: $6453-$ 6460.

62. Ellis, V., Behrendt, N., Dano, K. (1991). Plasminogen activation by receptor-bound urokinase. J. Biol. Chem. 266: 12752-12758.

63. Picone, R., Kajtaniak, E.L., Nielsen, L.S., Behrendt, N., Mastronocola, M.R., Cubellis, M.V., Stopelle,M.P., Pederson, S., Dano, K., Blasi, F. (1989). Regulation of urokinase receptors in monocyte-like U937 cells by phorbol ester phorbol myristate acetate. J. Cell Biol. 108: 693-702.

64. Stoppelli, M.P., Corti, A., Soffientini, A., Cassani, G., Blasi, F. Assoian, R.K. (1985). Differentiation-enhanced binding of the amino-terminal fragment of human urokinase plasminogen activators to a specific receptor on U937 monocytes. Proc. Natl. Acad. Sci. USA 82: 4939-4943.

65. Ellis, V., Scully, M.F., Kakkar, V.V. (1989). Plasminogen activator initiated by single-chain urokinase-type plasminogen activator. Potentiation by U937 monocytes. J. Biol. Chem. 264: 2185-2188.

66. Ellis, V., Dano, K. (1991). Plasminogen activation by receptor bound urokinase. Semin. Thromb. Hemost. 17: 194-200. 
67. Ellis, V., Wun, T., Behrent, N., Ronne, E., Dano, K. (1990). Inhibition of receptor-bound urokinase by plasminogen-activator inhibitors. J. Biol. Chem. 265: 9904-9908.

68. Pollanen, J., Saksela, O., Salonen, E.M., Andreasen, P., Nielsen,L., Dano, K., Vaheri, A. (1987). Distinct localisations of urokinase-type plasminogen activator and its type 1 inhibitor under cultured human fibroblasts and sarcoma cells. J. Cell Biol. 104: 1085-1096.

69. Estreicher, A., Muhlhauser, J., Carpentier, J., Orci, L., Vassalli, J. (1990). The receptor for urokinase type plasminogen activator polarizes expression of the protease to the leading edge of migrating monocytes and promotes degradation of enzyme inhibitor complexes. J. Cell Biol. 111: 783-792.

70. Hoyer-Hansen, G., Ronne, E., Solberg, H., Behrendt, N., Ploug, M., Lund, L.R., Ellis, V., Dano, K. (1992). Urokinase plasminogen activator cleaves its cell surface receptor releasing the ligand-binding domain. J. Biol. Chem. 267: 18224-18229.

71. Laiho, M., Keski-Oja, J. (1989). Growth factors in the relationship of pericellular proteolysis: a review. Cancer Res. 49: 2533-2553.

72. van Mourik, J.A, Lawrence, D.A., Loskutoff, D.J. (1984). Purification of an inhibitor of plasminogen activator (antiactivator) synthesized by endothelial cells. J. Biol. Chem. 259: 14914-14921. 
73. Ginsgurg, D., Zeheb, R., Yang, A.Y., Rafferty, U.M., Andreasen, P.A., Nielsen, L., Dano, K., Lebo, R.V., Gelehrter, T.D. (1986). CDNA cloning of human plasminogen activator inhibitor-inhibitor from endothelial cells. J. Clin. Invest. 78: 1673-1680.

74. Levin, E.G., Santell, L. (1987). Association of a plasminogen activator inhibitor with the growth substrata and membrane of human endothelial cells. J. Cell Biol. 105: 2543-2549.

75. Astedt, B., Lacander, I., Ny, T. (1987). The placental type plasminogen activator inhibitor PAI-2. Fibrinolysis 1: 203-208.

76. Scott, R.W., Baker, J.B. (1983). Purification of human protease nexin. J. Biol. Chem. 258: 10439-10444.

77. Mignatti, P., Rifkin, D.B. (1993). Biology and biochemistry of proteinases in tumour invasion. Physiological Reviews 73: 161-195.

78. Kwaan, H.C. (1992). The plasminogen-plasmin system in malignancy. Cancer and Metastasis Reviews 11: 291-311.

79. Duffy, M.J. (1987). Do proteases play a role in cancer invasion and metastasis? Eur. J. Cancer Clin Oncol. 23: 583-589.

80. Duffy, M.J., O'Grady, P., Devayey, D., O'Siorain, L., Fennelly, J.J., Lijnen, H.R. (1988). Tissue-type plasminogen activator, a new prognostic marker in breast cancer. Cancer Res. 48: 1348-1349. 
81. Duffy, M., O'Grady, P., Simon, J., Rose, M., Linjen, H.R. (1986). Tissuetype plasminogen activator in breast cancer: relationship with estradiol and progesterone receptors. J. Natl. Cancer Inst. 77: 621-623.

82. Duffy, M.J., Reilly, D., O'Sullivan, C., O'Higgins, N., Fennelly, J.J. (1990). Urokinase plasminogen activator and prognosis in breast cancer. Lancet 13: 108.

83. Janicke, F., Schmitt, M., Graeff, H. (1991). Clinical relevance of the plasminogen activators UPA and TPA and of their inhibitor PAI-1 in breast cancer. Semin. Thromb. Hemostasis. 17: 303-312.

84 Janicke, F., Schmitt, M., Hafter, R., Hollreider, A., Babic, R., Ulm, K., Gussner, W., Graeff, H. (1990). Urokinase-type plasminogen activator (UPA) antigen is a predictor of early relapse in breast cancer. Fibrinolysis 4: 69-78.

85. Schmitt, M., Goretzki, L., Janicke, J., Calvete, M., Eulitz, M., Kobayashi, H., Chucholowski, N., Graeff, H. (1991). Biological and clinical relevance of the urokinase-type plasminogen activator (UPA) in breast cancer. Biomed. Biochim. Acta 50: 731-741.

86. Schmitt, M., Janicke, F., Graeff, H. (1990). Tumor-associated fibrinolysis: the prognostic relevance of plasminogen activators UPA and tPA in human breast cancer. Blood Coag. Fibrinol. 1: 695-702. 
87. De Bruin, P.A., Griffioen, F.G., Verspaget, H.W., Verheijen, J., Dooijewaard, G., Van der Ingh, H.F., Lamers, B.H.W. (1988). Plasminogen activator profiles in neoplastic tissues of the human colon. Cancer Res. 48: 45204524.

88. Boyd, D., Florent, G., Kim, P., Brattain, M. (1988). Determination of the levels of urokinase and its receptor in human colon carcinoma cell lines. Cancer Research 48: 3112-3116.

89. Oka, T., Ishida, T., Nishino, T., Sugimachi, K. (1991). Immunohistochemical evidence of urokinase-type plasminogen activator in primary and metastatic tumours of pulmonary adenocarcinoma. Cancer Res. 51: 3522-3525.

90. Wang, B.S., McLoughlin, G.A., Richie, J.P., Mannick, J.A. (1980). Correlation of the production of plasminogen activator with tumour metastasis in B16 mouse melanoma cell lines. Cancer Res. 40: 288-292.

91. Quax, P.H.A., van Muijen, G.N.P., Weening-Verhoof, E.J.D., Lund, L.R., Dano, K, Ruiter, D.J., Verheijen, J.H. (1991). Metastatic behaviour of human melanoma cell lines in nude mice correlates with urokinase-type plasminogen activator, it's type-1 inhibitor, and urokinase-mediated matrix degradation. J. Cell Biol. 115: 191-199.

92. Yagel, S., Khokha, R., Denhardt, D.T., Kerbel, R.S., Parhar, R.S., Lala, P.K. (1989). Mechanisms of cellular invasiveness: a comparison of amnion 
invasion in vitro and metastatic behaviour in vivo. J. Natl. Cancer Inst. 81: 768-775.

93. Hollas, W., Blasi, F., Boyd, D. (1991). Role of the urokinase receptor in facilitating extracellular matrix invasion by cultured colon cancer cells. Cancer Res. 51: 3690-3695.

94. Reiter, L.R., Kruithof, E.K.O., Cajot, J, Sordat, B. (1993). The role of the urokinase receptor in extracellular matrix degradation by HT29 human carcinoma cells. Int. J. Cancer 53: 444-450.

95. Ossowski, L. (1988). In vivo invasion of modified chorioallantoic membrane by tumor cells: the role of cell surface-bound urokinase. J. Cell Biol. 107: 2437-2445.

96. Ossowski, L., Clunie, G., Masucci, M.T., Blasi, F. (1991). In vivo paracrine interaction between UPA and its receptor. J. Cell Biol. 115: 1107-1112.

97. Pyke, C., Kristensen, P., Ralfkiaer, E., Grondahl-Hansen, J., Eriksen, J., Blasi, F., Dano, K. (1991). Urokinase-type plasminogen activator is expressed in stromal cells and its receptor in cancer cells at invasive foci in human colon adenocarcinomas. Am. J. Pathol. 138: 1059-1067.

98. Tsuboi, R., Rifkin, D.B. (1990). Bimodal relationship between invasion of the amniotic membrane and plasminogen activator activity. Int. J. Cancer 46: $56-60$. 
99. Montgomery, A.M.P., De Clerck, Y.A., Langley,K.E., Reisfeld, R.A., Mueller, B.M. (1993). Melanoma-mediated dissolution of extracellular matrix: contribution of urokinase-dependant and metalloproteinase-dependant proteolytic pathways. Cancer Res. 53: 693-700.

100. Ossowski, L. (1992). Invasion of connective tissue by human carcinoma cell lines: requirement for urokinase, urokinase receptor and interstitial collagenase. Cancer Res. 52: 6754-6760.

101. Meissauer, A., Kramer, M.D., Hofmann, M., Erkell, L.J., Jacob,E., Schirrmacher, V., Brunner, G. (1991). Urokinase-type and tissue-type plasminogen activators are essential for in vitro invasion of human melanoma cells. Exp. Cell Res. 192: 453-459.

102. Meissauer, A., Kramer, M.D., Schirrmacher, V., Brunner, G. (1992). Generation of cell surface-bound plasmin by cell-associated urokinasetype or secreted tissue-type plasminogen activator: a key event in melanoma cell invasiveness in vitro. Exp. Cell Res. 199: 179-190.

103. Ossowski, L., Reich, E. (1983). Antibodies to plasminogen activator inhibit human tumor metastasis. Cell 35: 611-619.

104. Ossowski, L. (1988). Plasminogen activator dependant pathways in the dissemination of human tumor cells in the chick embryo. Cell 52: 321-328.

105. Ossowski, L., Russo-Payne, H., Wilson, E.L. (1991). Inhibition of urokinase-type plasminogen activator by antibodies: The effect on 
dissemination of a human tumour in the nude mouse. Cancer Res. 51: 274-281.

106. Hearing, V.J., Law, L.W., Corti, A.C., Appella, E., Blasi, B. (1988). Modulation of metastic potential by cell surface urokinase of murine melanoma cells. Cancer Res. 48: 1270-1278.

107. Yu, H., Schultz, R.M. (1990). Relationship between secreted urokinase plasminogen activity and metastatic potential in murine B16 cells transfected with human urokinase sense and antisense genes. Cancer Res. 50: 7623-7633.

108. Axelrod, J.H., Reich, R., Miskin, R. (1989). Expression of human recombinant plasminogen activators enhances invasion and experimental metastasis of H-ras-transformed NIH 3T3 cells. Mol. Cell. Biol. 9: 21332141.

109. Lund, L.R., Romer, J., Ronne, E., Ellis, V., Blasi, F., Dano, K. (1991). Urokinase receptor biosynthesis, mRNA level and gene transcription are increased by transforming growth factor beta-1 in human $A 549$ lung carcinoma cells. Biochem. Biophys. Res. Commun. 155: 418-422.

110. Teale, D.M., Khidair, I.A., Potter, C.W., Rees, R.C. (1988). Modulation of type IV collagenase and plasminogen activator in a hamster fibrosarcoma by basement membrane components and lung fibroblast. Br. J. Cancer 57: $475-480$. 
111. Bal De Kir Joffe, E., Alfonso,D.F., Puricelli, L. (1991). Soluble factors released by the target organ enhance the urokinase-type plasminogen activator activity of metastatic tumor cells. Clin. Exp. Metast. 9: 51-56.

112. Saksela, O., Rifkin, D.B. (1990). Release of basic fibroblast growth factorheparan sulfate complexes from endothelial cells by plasminogen activatormediated proteolytic activity. J. Cell Ciol. 110: 767-775.

113. Wilson, E.L., Becker, M.L.B., Hoal, E.G., Dowdle, E.B. (1980). Molecular species of plasminogen activators secreted by normal, reactive and neoplastic human cells. Cancer Res. 40: 933.

114. Wilson, E.L., Jacobs, P., Dowdle, E.B. (1983). The secretion of plasminogen activators by human myeloid leukemic cells in vitro. Blood 61:568-574.

115. Reik et al. (1987). Isolation of monoclonal antibodies against cytochrome p450 isozymes. J. Immunol. Meth. 100: 123-130.

116. Laug, W.E., Wang, K., Mundi, R., Rideout III, W., Kruithof, E.K.O., Bogenmann, E. (1992). Clonal variation of expression of the genes coding for the plasminogen activators, their inhibitors and the urokinase receptor in HT1080 sarcoma cells. Int. J. Cancer 52: 298-304.

117. Gunning, P., Porte, D., Okayama, H., Engel, J, Blau, H., Kedes, L. (1983). Isolation and characterisation of full length CDNA clones for human $\alpha-\beta$ and $\gamma$-actin mRNAs. Mol. Cell. Biol. 3: 787-795. 
118. Verde, P., Stopelli, M.P., Galeffi, P., Di Nocera, P., Blasi, F. (1984). Identification and primary sequence of an unspliced human urokinase poly(A) ${ }^{+}$RNA. Proc. Nat. Acad. Sci. U.S.A. 81: 4727-4731.

119. Friezner-Degen, S.J., Rajput, B., Reich, E. (1986). The human tissue plasminogen activator gene. J. Biol. Chem. 261: 6972-6985.

120. Ny, T., Sawdey, M., Lawrence, D.A., Millam, J.L., Loskutoff, D.J. (1986). Cloning and sequence of a cDNA coding for the human $\beta$-migrating endothelial-cell-type plasminogen activator inhibitor. Proc. Natl. Acad. Sci. USA 83: 6776-6780.

121. Hoal, E.G. (1981). An experimental study of human melanoma cells cultured in vitro. PhD thesis (U.C.T).

122. Hashimoto, K., Horikoshi, T., Nishioka, K., Yoshikawa, K., Carter, D.M. (1986). Plasminogen activator secreted by cultured human melanocytes. Br. J. Dermatol. 115: 205-209.

123. Dano, K., Andreason, P.A., Gronhal-Hansen, J., Kristensen, P., Nielsen, L.S., Skriver, L. (1985). Plasminogen activators, tissue degradation and cancer. Advanc. Cancer Res. 44: 139-26.

124. Saksela, O., Rifkin, D.B. (1988). Cell-associated plasminogen activation: regulation and physiological functions. Annu. Rev. Cell Biol. 4: 93-126. 
125. Weintraub, H.M. (1990). Antisense RNA and DNA. Sci. Am. Jan 1990.

126. Neckers, L., Whitesekk, L., Rosolen, A., Geselowitz, D.A. (1992). Antisense inhibition of oncogene expression. Crit. Rev. Oncol. 3(1,2): 175231.

127. Cech, T.R., (1987). The chemistry of self-splicing RNA and RNA enzymes. Science 236:1532-1539.

128. Cameron, F.H., Jennings, P.A. (1989). Specific gene suppression by engineered ribozymes in monkey cells. Proc. Natl. Acad. Sci. USA 86: 9139-9143.

129. Sioud, M. Natvig, J.B., Forre, O. (1992). Preformed ribozyme destroys tumour necrosis factor mRNA in human cells. J. Mol. Biol. 223: 831-835.

130. Saxena, S.K., Ackerman, E.J. (1990). Ribozymes correctly cleave a model substrate and endogenous RNA in vivo. J. Biol. Chem. 265: 17106-17109.

131. Haseloff, J., Gerlach, W.L. (1988). Simple RNA enzymes with new and highly specific endoribonuclease activities. Nature 334: 585-591.

132. Higgins, C.H., Gottesman, M.M. (1992). Is the multidrug transporter a flippase? Trends Biochem. Sci. 17(1): 18-21.

133. Boggs, S.S., Gregg, R.G., Borenstein, N., Smithies, O. (1986). Efficient transformation and frequent single site copy insertion of DNA can be 
obtained in mouse erytholeukemia cells transformed by electroporation. Exp. Hematol. 14(10): 988-994.

134. Heidenreich, O., Eckstein, F. (1992). Hammerhead ribozyme-mediated cleavage of the long terminal repeat of human immunodeficiency virus type 1. J. Biol. Chem. 267: 1904-1909.

135. Granelli-Piperno, A., Reich, E. (1978). A study of proteases and proteaseinhibitor complexes in biological fluids. J. Exp. Med 148: 223.

136. Maniatis, T., Fritsch, E.F., Sambrook, J. (1989). Molecular cloning. A laboratory manual (2nd ed.). Cold Spring Harbor, N.Y: Cold Spring Harbor Laboratory.

137. Reinders, J.H., Jansen, J.W.C.M., Duphar, B.V. (1991). Fibrinolysis. Duphar Pharmacology Poster. 